\title{
Risk assessment of contaminants of emerging concern in the context of wastewater reuse for irrigation: An integrated modelling approach
}

Delli Compagni, Riccardo ; Gabrielli, Marco; Polesel, Fabio; Turolla, Andrea; Trapp, Stefan; Vezzaro, Luca; Antonelli, Manuela

\section{Published in:}

Chemosphere

Link to article, DOI:

10.1016/j.chemosphere.2019.125185

Publication date:

2020

Document Version

Peer reviewed version

Link back to DTU Orbit

Citation $(A P A)$ :

Delli Compagni, R., Gabrielli, M., Polesel, F., Turolla, A., Trapp, S., Vezzaro, L., \& Antonelli, M. (2020). Risk assessment of contaminants of emerging concern in the context of wastewater reuse for irrigation: An integrated modelling approach. Chemosphere, 242, [125185]. https://doi.org/10.1016/j.chemosphere.2019.125185

\section{General rights}

Copyright and moral rights for the publications made accessible in the public portal are retained by the authors and/or other copyright owners and it is a condition of accessing publications that users recognise and abide by the legal requirements associated with these rights.

- Users may download and print one copy of any publication from the public portal for the purpose of private study or research.

- You may not further distribute the material or use it for any profit-making activity or commercial gain

- You may freely distribute the URL identifying the publication in the public portal 
1 Risk assessment of contaminants of emerging concern in the context of

2 wastewater reuse for irrigation: An integrated modelling approach

3

4 Riccardo Delli Compagni ${ }^{1}$, Marco Gabrielli ${ }^{1}$, Fabio Polesel $^{2,3}$, Andrea Turolla ${ }^{1}$, Stefan Trapp ${ }^{2}$, Luca

$5 \quad$ Vezzaro $^{2}$, Manuela Antonelli ${ }^{*}$

6

$7{ }^{1}$ Politecnico di Milano, Department of Civil and Environmental Engineering (DICA), Piazza

8 Leonardo da Vinci 32, 20133 Milano, Italy

92 DTU Environment, Technical University of Denmark, Bygningstorvet, Building 115, 2800

10 Kongens Lyngby, Denmark

$11{ }^{3}$ DHI A/S, Agern Allé 5, 2970 Hørsholm, Denmark

12

13 *Corresponding author: manuela.antonelli@polimi.it 


\section{Abstract:}

Direct reuse of reclaimed wastewater $(\mathrm{RWW})$ in agriculture has recently received increasing attention as a possible solution to water scarcity. The presence of contaminants of emerging concern (CECs) in RWW can be critical, as these chemicals can be uptaken in irrigated crops and eventually ingested during food consumption.

In the present study, an integrated model was developed to predict the fate of CECs in water reuse systems where RWW is used for edible crops irrigation. The model was applied to a case study where RWW (originating from a municipal wastewater treatment plant) is discharged into a water channel, with subsequent irrigation of silage maize, rice, wheat and ryegrass. Environmental and human health risks were assessed for 13 CECs, selected based on their chemical and hazard characteristics. Predicted CEC concentrations in the channel showed good agreement with available measurements, indicating potential ecotoxicity of some CECs (estrogens and biocides) due to their limited attenuation. Plant uptake predictions were in good agreement with existing literature data, indicating higher uptake in leaves and roots than fruits. Notably, high uncertainties were shown for weakly acidic CECs, possibly due to degradation in soil and $\mathrm{pH}$ variations inside plants. The human health risk due to the ingestion of wheat and rice was assessed using the threshold of toxicological concern and the hazard quotient. Both approaches predicted negligible risk for most CECs, while sulfamethoxazole and $17 \alpha$-ethinylestradiol exhibited the highest risk for consumers. Alternative scenarios were evaluated to identify possible risk minimization strategies (e.g., adoption of a more efficient irrigation system).

Keywords: dietary intake; micropollutants; model-based risk assessment; plant uptake 


\section{Introduction}

39 Water scarcity induces monetary and job losses throughout all continents (Asano, 2002; Ding et al., 40 2011) and the situation is expected to worsen due to population growth, increase of water use per capita, climate change and other stress factors (IPCC, 2014; Gosling and Arnell, 2016). Following circular economy principles, the reuse of reclaimed wastewater (RWW) originating from urban wastewater treatment plants (WWTPs) is identified as one of the main measures to alleviate fresh water depletion (COM/2015/614). This can be a valid alternative to water supply for agricultural irrigation, the largest source of freshwater consumption worldwide (COM/2015/614). This approach has recently been promoted by the European Union, which also proposed minimum requirements for a safe reuse (COM/2018/337). This document acknowledges the need of assessing the risk (where relevant) associated to contaminants of emerging concern (CECs), whose threat for environment and human health is well recognized (Daughton and Ternes, 1999; Monteiro and Boxall, 2010).

51 Existing WWTPs are typically not designed for removal of CECs (e.g. pharmaceuticals, estrogens, biocides), which are generally released from households into sewer systems (Luo et al., 2014; Castiglioni et al., 2018). Hence, some CECs persist in RWW and can reach agricultural fields through irrigation, leading to accumulation in soil (Durán-Alvarez et al., 2009; Gibson et al., 2010) and contamination of groundwater (Siemens et al., 2008; Lesser et al., 2018). Irrigated crops can also accumulate CECs in roots (Miller et al., 2016) and translocate them towards edible plant organs such as leaves and fruits (Goldstein et al., 2014; Christou et al., 2017). Consequently, potential exposure of humans and organisms living in environmental recipients to CECs requires a 59 careful assessment, and adverse effects can be quantified based on the estimated exposure 60 concentrations (Piña et al., 2018). Besides being discontinuous in time and subject to uncertainty

61 (due to e.g. analytics), empirical measurements of environmental CEC levels are site-specific and 62 do not allow extrapolating contamination levels to other RWW reuse systems. In this case, 
63 modeling tools can contribute with valuable complementary information (e.g. filling temporal gaps

64 between measurements), and account for the influence of site-specific conditions. The use of complex modelling tools, especially for integrated systems, can be challenged by parameter identifiability (Voinov and Shugart, 2013; Bach et al., 2014) and limited input data availability.

67 These sources of uncertainty can be addressed by using statistical analysis methods (e.g., sensitivity 68 and uncertainty analysis), allowing the identification of important model factors and the 69 quantification of results uncertainty. So far, integrated models have shown the ability of evaluating 70 the impacts of discharges from storm- and wastewater system on the chemical status of surface

71 water (De Keyser et al., 2010). However, a dynamic chemical fate model capable of estimating 72 CEC concentrations (and thereby risk) in different environmental compartments (surface water, 73 soil, crops) under different water management and reuse scenarios is currently in high need.

74 The objective of this work was to develop a flexible integrated model to predict CEC fate in different types of RWW reuse systems, irrespective of size and complexity, and to assess environmental and human health risks. The model was: (i) applied to a real RWW reuse scenario, comprising a discharge channel and cultivation of four different types of crops (silage maize, rice, wheat and ryegrass); (ii) verified with site-specific measurements, where available, and literature 79 data in different compartments; (iii) used to estimate the environmental risk associated to CEC 80 occurrence in surface water, and human health risk following the ingestion of irrigated crops; (iv) 81 used to evaluate alternative risk management and minimization scenarios, which were compared to 82 the present situation and to a worst-case scenario (characterized by the absence of a WWTP). 


\section{Materials and methods}

\subsection{Fate model development and evaluation}

A generic RWW reuse system was considered to include a surface water body, receiving RWW discharges, and cultivated fields with irrigation. The river water quality model extended with CEC fate processes (from the IUWS_MP library) (Vezzaro et al., 2014) and the coupled soil-plant model (CSPM) (Trapp and Matthies, 1998; Trapp, 2017) were identified as the state-of-the-art models (section 2.1.1) to describe CECs fate in the generic system. These models were extended (section 2.1.2) to increase their applicability and coupled (section 2.1.3). A sensitivity analysis (section 2.1.4) was also performed to identify the most significant parameters in the developed model.

\subsubsection{State of the art models}

The IUWS_MP library (Vezzaro et al., 2014) utilizes a conceptual approach to simulate river water quality, where water transport is simulated by a series of continuously stirred tanks reactors (CSTRs). Each CSTR consists of two compartments (bulk water and sediments), in which fate processes (abiotic and biotic degradation, sorption to suspended solids and colloids) occur.

The CSPM includes (i) a tipping bucket model to describe the movement of water and dissolved 100 CECs through soil and (ii) a numerical four-compartment model to simulate CEC uptake and 101 translocation through xylem and phloem flows, in roots, stem, leaves and fruits. Partitioning 102 between plant tissues and soil, and xylem and phloem flows is described through a detailed 103 intracellular model (Trapp, 2004; Trapp and Horobin, 2005; Trapp, 2009; Trapp 2017).

\subsubsection{Model extensions}

106 Many CECs are ionized at environmental $\mathrm{pH}$, which affects their partitioning behavior (Franco et 107 al., 2010). Hence, the equations described in Franco and Trapp (2008) were included in the IUWS_MP library to describe sorption of ionized monovalent acidic and basic compounds. 
In the CSPM, phloem flow introduced to improve the dynamics of the internal plant circulation, 110 through which weakly acidic CECs translocate from leaves through stem to fruits and roots 111 (Gonzalez-Garcia et al., 2019; Kleier \& Hsu, 1996).

112 Model structures were further modified to accommodate for temporal and spatial dynamics of 113 environmental conditions (e.g., air, soil and water temperature, water and soil $\mathrm{pH}$, sunlight intensity, 114 etc.), which can substantially affect CEC fate (Kunkel and Radke, 2011; Matamoros and Rodriguez, 115 2017). Moreover, the CSPM was also modified to simulate complex types of irrigational systems, in 116 which water can partially submerge the cultivations (e.g. rice). Particularly, the field capacity of the 117 first soil layer was adjusted to simulate the saturation effect introduced by a standing water layer. 118 The reader is referred to the Supplementary Material (SM) for a detailed description of the 119 extensions of the IUWS_MP library and of CSPM model.

2.1.3 Model coupling and software selection

122 Predicted CEC concentrations were obtained twice a day (noon and midnight) from the river model 123 (implemented in WEST 2014®, DHI A/S, Denmark) to consider high and low peaks, and input to 124 the CSPM (implemented in Microsoft Excel), which provided daily outputs.

\subsubsection{Identification of influential parameters}

127 A sensitivity analysis (SA) was performed to identify: (i) the most influential model parameters for concentration predictions and (ii) non-sensitive model parameters uncertainties, which could be 129 fixed to a default value without affecting model predictions uncertainties. As for the river model, a 130 one-at-a-time (OAT) approach (Frey and Patil, 2002) was performed by varying each parameter $131 \pm 5 \%$ from its default value. A total of 52 parameters were investigated. The variation in predicted concentrations was calculated as reported in Equation 1: 


$$
\text { Deviation }=\frac{1}{n} \sum_{i}^{n} \frac{y_{i}^{p, \max }-y_{i}^{p, \min }}{y_{i}^{p, \text { default }}}
$$

133 where $y_{i}^{p, \text { max }}, y_{i}^{p, \text { min }}, y_{i}^{p, \text { default }}$ are the predicted concentrations obtained with the maximum, 134 minimum and default values of the parameter $p$ for $i^{\text {th }}$ time step; $n$ is the number of time steps in the 135 simulation. Three CECs (i.e. diclofenac, triclosan and carbamazepine, see section 2.2.1) were 136 chosen as benchmark for different physicochemical properties. Parameters influencing predicted 137 concentrations were also assessed for four conventional pollutants (ammonia, nitrite, nitrate and 138 phosphorus).

139 As for the SA of CSPM, partial rank correlation coefficients (PRCCs) (Saltelli et al., 1993) were 140 calculated through the software Crystal Ball 11.1.2 (Oracle $\left.{ }^{\circledR}\right)$. First, 1000 runs were conducted by 141 varying separately plant and soil parameters. The parameters presenting |PRCCs| above 0.1 were 142 selected and included into a second SA of 10000 runs. This time, parameters with |PRCCs| 143 exceeding $\sqrt{1 / n}$ (with $n$ being the number of parameters varied in each simulation) were identified 144 as relevant. The validity of the PRCCs was checked through the $\mathrm{R}^{2}$ between the two sets of ranks 145 (Sin et al., 2011). The second SA was carried out both with and without degradation in soil to better 146 highlight its sensitivity on model variations.

\subsection{Model testing}

149 The developed model was tested on an existing Italian case study, where RWW from a municipal 150 WWTP (flow $=3.5 \mathrm{~m}^{3} \mathrm{~s}^{-1}$ ) is the only source providing water through a surface water channel to 151 subsequently irrigate crop fields. The channel extends for about $12 \mathrm{~km}$ and provides irrigation water 152 for 90 farms with more than $40 \mathrm{~km}^{2}$ of crop fields (Pizza, 2014). Cultivated crops include winter 153 wheat and rice, which are sold for human food consumption; and silage maize and ryegrass that are 154 used for animal feed production. Irrigation systems included surface irrigation, the dominant form 
155 of irrigation in southern European countries (Masseroni et al., 2017) for all the crops but rice, which 156 is grown in paddies. In the area, crop rotation is a standard procedure and is performed each season.

\subsubsection{Chemicals}

159 Thirteen CECs of different classes of use were assessed: clarithromycin (CLA), sulfamethoxazole 160 (SMX), diclofenac (DCF), ibuprofen (IBU), paracetamol (PAR), carbamazepine (CBZ), furosemide 161 (FUR), 17- $\alpha$ ethinylestradiol (EE2), 17- $\beta$ estradiol (E2), estrone (E1), perfluorooctanoic acid 162 (PFOA), perfluorooctane sulfonate (PFOS) and triclosan (TCS). These CECs were selected from an 163 initial group of 80 CECs, for which measurements were available at the outlet of the WWTP 164 (Castiglioni et al., 2018a, 2018b). Specifically, two criteria were used: i) selected CECs had to 165 cover a broad range of physicochemical properties in terms of: air/water partitioning coefficient $166\left(K_{a w}\right)$, normalized organic carbon partitioning coefficients $\left(K_{o c}\right)$, and ionization state at 167 environmental $\mathrm{pH}$; ii) selected CECs had to belong to different CEC classes (e.g. antibiotics, 168 hormones, etc.) and to possibly exceed the predicted no-effect concentration (PNEC). 169 Physicochemical properties (Table S2) and degradation rates (Tables S3-S15) of the selected CECs 170 were collected from literature (see SM for sources) and/or retrieved from QSAR software 171 (Advanced Chemistry Development Inc., 2015; National Food Institute, Technical University of 172 Denmark, 2018).

\subsubsection{System conceptualization}

175 The RWW reuse system was conceptualized as shown in Figure 1. The channel was described by 176 the river modules from the IUWS_MP library, resulting in 11 in-series CSTRs, each one 177 approximately $500 \mathrm{~m}$ long. This length was selected in agreement with Benedetti et al. (2004) as a 178 compromise between the need of simulating temporal dynamics in a realistic way and the required 179 computational effort. Within the channel, nine equidistant locations were selected, each having 
180 irrigation water withdrawal that was proportional to the required water demand to harvest the 181 closest crops. The water demand $\left(\mathrm{m}^{3} \mathrm{~d}^{-1}\right)$ was defined as the product of the water consumption to 182 harvest one unit of land and total land extension (Brouwer et al., 1992). Crop types and 183 corresponding extensions were derived from georeferenced maps of the area 184 (www.geoportale.regione.lombardia.it) and elaborated with QGIS 2.18. Periods of water 185 withdrawal and crop rotation were simulated according to the irrigation calendars (Figure 1b) based 186 on agronomic information of the area (Nelli and Sodi, 2007; Provincia di Milano, 2007; Borrelli et 187 al., 2014; Moretti et al., 2015). Two water withdrawal scenarios were considered: (i) scenario $M R$, 188 where silage maize and ryegrass were grown at the same time of rice and ryegrass and, (ii) scenario $189 M W$, where silage maize and ryegrass were grown at the same time of winter wheat. Moreover, 190 different irrigation systems were simulated depending on crop types: (i) a monthly irrigation water 191 pulse for silage maize, ryegrass and winter wheat and, (ii) a continuous irrigation for rice. Three 192 types of soils were found predominantly in the study area, with more than one crop per type of soil 193 (see Table S18). For this reason, crop simulations were repeated for different soils. The simulated 194 soil structure was also adapted to match the identified stratigraphy for a soil depth of $1 \mathrm{~m}$, splitting 195 (if needed) the widest horizons over two layers. 


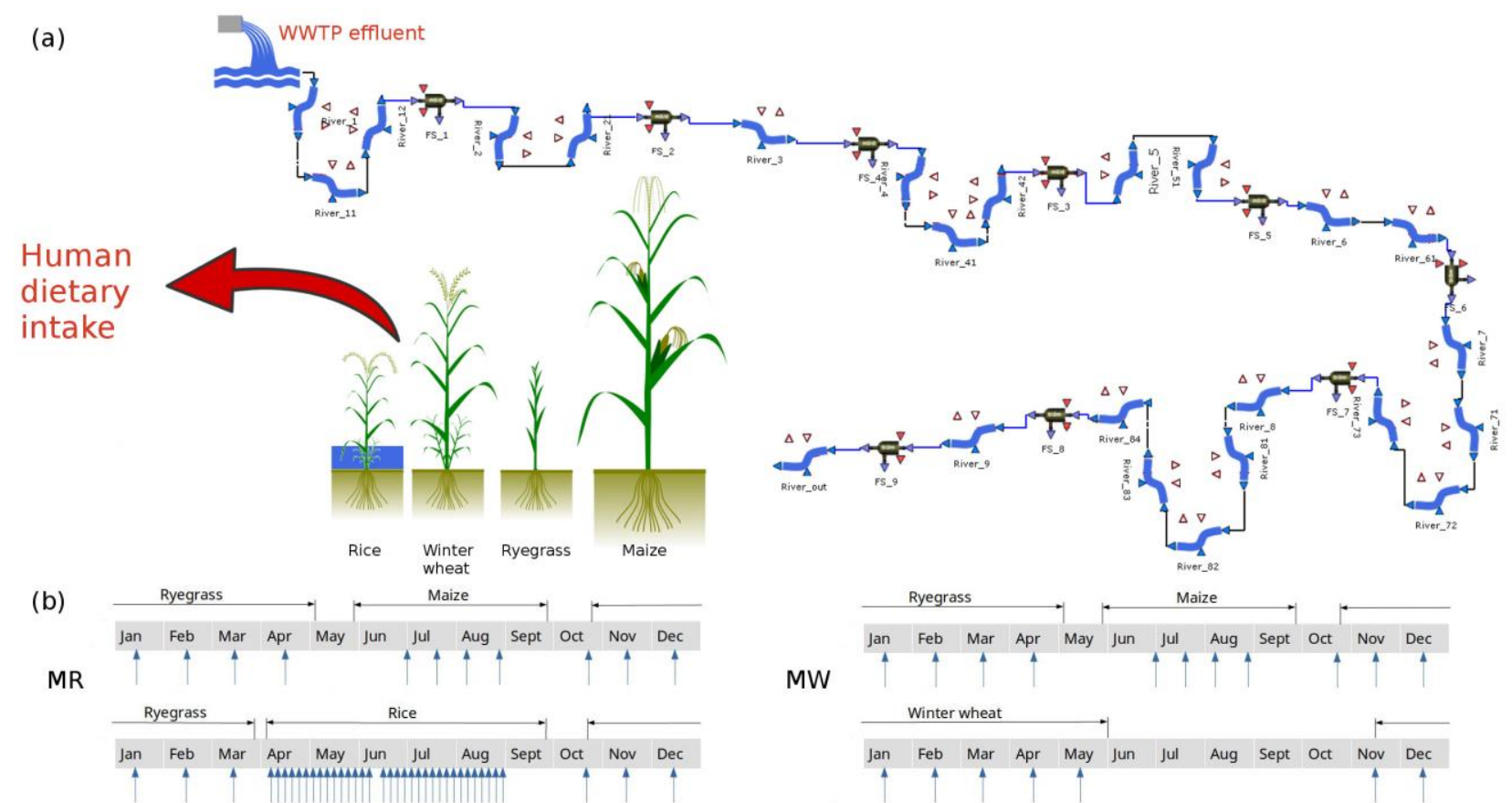

Figure 1. Outline of the wastewater reuse system (a) and irrigation calendars (b) for the two crop rotation scenarios.

\subsubsection{Model input and parameters}

202 Concentrations of conventional pollutants in RWW (i.e. ammonia, nitrite, nitrate and phosphorus) 203 represented a 24-hour time-proportional composite sample and were retrieved from the laboratory 204 measurements conducted by WWTP staff. CEC concentrations in RWW were obtained from 205 previous measurements at the outlet of the WWTP (Castiglioni et al., 2018a, 2018b) and assumed constant over the year. Such assumption can be held valid for CECs (e.g., DCF and CBZ) that show low to no seasonal fluctuations in usage (Sui et al., 2011). For antibiotics such as CLA, for which 208 seasonal fluctuations were observed (McArdell et al., 2003), measurements may reflect a worst-case 209 scenario as campaigns were conducted during winter time. Environmental conditions (Tables S16210 17) were directly obtained from public databases or indirectly estimated (e.g., potential evaporation, 211 soil temperature, bulk density and water retention properties). Crop-specific data (Table S19) were 212 collected from literature preferring, where available, local sources. Soil initial conditions (CECs 
213 concentrations and water content) were assumed equal to the pseudo-steady state reached using the

214 median CECs. For more details, the reader is referred to SM.

\subsubsection{Uncertainty propagation}

217 The uncertainty associated to CEC concentrations in RWW and transformation rates (e.g., aerobic 218 degradation in water, photodegradation and aerobic/anoxic degradation in sediments) were 219 propagated to the predicted concentration in the surface water channel through a Monte-Carlo based 220 Uncertainty Analysis (UA). Uniform, triangular or empirical parameter distributions were chosen 221 based on literature values (Tables S3-S15). For every CEC, 2000 runs were performed.

222 Resulting uncertainties in the predicted CEC concentrations along the river were then propagated, 223 together with soil degradation rates and influential crop parameters, to CSPM predictions. 224 Specifically, triangular distributions were considered for soil degradation rates and CEC concentrations. Crop parameters were considered as uniformly distributed with a variation of $\pm 10 \%$ from literature data (Felle, 2001). Attention was paid to avoid parameter combinations that may lead to non-realistic scenarios (Steinwand et al., 2001). 2000 latin-hypercube Monte Carlo runs were performed for each CEC and soil type (Table S18). Physicochemical properties (Table S2) of perfluorinated compounds exhibited a high degree of uncertainty due to analytical limitations 230 (Wang et al., 2011), and were thus included in UA. More details on UA are provided in SM.

\subsection{Model objectives}

233 The three main objectives of the developed integrated model were:

$234 I-$ Fate predictions and assessment of model performance: long term simulations ( $\geq 1$ year) were 235 performed to assess CECs fate in surface water, irrigated crops and groundwater. Assessment of 236 model performance was carried out by comparing model predictions with site-specific 237 measurements, where available (as for DCF) and/or literature data. For the surface water channel, 
further verification was made by deriving first-order attenuation rates by fitting predicted median

239 concentrations at different locations and comparing to experimental literature data. In this case, 240 overall attenuation derives from the combination of different biotic and abiotic degradation 241 processes.

242 As for the uptake in crops, the bioconcentration factor (BCF, $\mathrm{g}_{\mathrm{dw}}{ }^{-1} \mathrm{~g}^{-1} \mathrm{dw}$ ) was calculated as $243 C_{\text {organ }} / C_{\text {soil }}$, where $C_{\text {organ }}$ and $C_{\text {soil }}$ are the predicted dry weight concentrations in a given plant organ 244 (root, stem, leaf, fruit) and in the first soil layer. There is currently limited consensus on calculation 245 of BCFs since different approaches have been considered with respect to $C_{\text {soil }}$ values (Polesel et al., 246 2015). For this reason, both the simulated maximum and median soil concentrations were used for 247 the $\mathrm{BCF}$ calculation, corresponding to $\mathrm{BCF}_{\max }$ and $\mathrm{BCF}_{\text {median, }}$, respectively. Calculated $\mathrm{BCF}$ was 248 compared with literature (when not explicitly reported, empirical BCFs were derived from reported 249 concentration data) except for CLA, which showed limited plant uptake (Limmer and Burken, 250 2014; Lamshoeft et al., 2018). Predicted leaching of CECs into groundwater was also compared 251 with measurements from the nearby area.

II - Ecological and human health risk assessment: environmental risk assessment was carried out 254 through the risk quotients (RQs) (Hernando et al., 2006; Kuzmanovic et al., 2013). RQs were 255 calculated for each CEC as $P E C / P N E C$, where $P E C$ is the predicted environmental concentration and PNEC the predicted no-effect concentration. PNECs were obtained from literature (Table S1) 257 and PECs were the predicted concentrations at the end of the surface water channel; specifically, 258 maximum, median and minimum concentrations were predicted to obtain $R Q_{\max }, R_{\text {median }}$ and $259 \mathrm{RQ}_{\min }$, respectively. Two alert thresholds of RQ above 0.1 and 1 were identified as medium and 260 high risk, respectively (Hernando et al., 2006). Monthly frequency of exceedance above the alert 261 thresholds was calculated as additional risk indicator. 
262 The human health risk associated to dietary intake was calculated with two different approaches: the 263 threshold of toxicological concern (TTC) (Kroes et al., 2004; Malchi et al., 2014) and the hazard 264 quotient (HQ) (Prosser et al., 2014b; Prosser and Sbiley, 2015). TTC values were obtained through 265 the Cramer classes decision tree implemented in the Toxtree v3.1 software (Patlewicz et al., 2008) 266 and used to calculate the crop ingestion required for posing a risk as (BW TTC)/ $\mathrm{C}_{\mathrm{fw}}$ ], where $\mathrm{BW}$ 267 ( $\mathrm{kg})$ is the reference body weight (EFSA, 2012) and $\mathrm{C}_{\mathrm{fw}}\left(\mu \mathrm{g} / \mathrm{kg}_{\mathrm{dw}}\right)$ is the CEC concentration in the 268 edible part, based on fresh weight. These values were then compared with typical Italian food 269 consumption rates for infants and adults (Leclercq et al., 2009). HQs were calculated as the ratio 270 between the estimated daily intake (EDI) and the admissible daily intake (ADI), which is the 271 amount of CECs that can be consumed daily over a person's lifespan without evocating an adverse 272 effect. The level of concern was set to 0.1 as dietary ingestion represents a single pathway of 273 exposure (Prosser and Sibley, 2015). Hazard Index (HI) was also calculated as the sum of HQs to 274 provide a conservative first-tier estimate of the mixture risk (Prosser and Sibley, 2015; Evans et al., 275 2015). Median and $97.5 \%$ percentile were derived for HQ, TTC and HI values from UA 276 propagation. Further details on the two methods are given in SM.

277 III - Management scenarios analysis

278 Two agronomic management strategies were simulated to assess their potential for human health 279 risk mitigation compared to the existing surface irrigation:

280 (i) the adoption of sprinklers, which require a lower investment cost than drip irrigation, and 281 are a more efficient irrigation system than surface irrigation (i.e. irrigation efficiency 282 increases from $60 \%$ to $75 \%$ according to Brouwer et al., 1989);

283 (ii) one week extension of the period without irrigation before harvest (also known as crop284 drying stage). Waiting periods before harvest are a commonly required health safety measure in case of biosolids application (Prosser et al., 2014b). 
286 The benefits in terms of human health risk reduction of the existing WWTP, although not 287 specifically designed to remove CECs, were simulated in a specific scenario, where untreated 288 wastewater was directly used for irrigation. Specifically, CEC concentrations measured in WWTP 289 influent (Castiglioni et al., 2018a) were used as input to the river model and first order attenuation 290 rates (calculated beforehand) were used to estimate PECs at the end of the channel. Based on PECs 291 as input, the CSPM was then used to predict concentrations in fruits, allowing to estimate dietary 292 intake and health risk for infants as shown earlier. 


\section{Results and discussion}

3.1 Sensitivity analysis

295 Among the 52 parameters of the river model in the IUWS_MP library, 12 parameters (Figure S2)

296 had an impact on predicted CEC concentrations. The fraction of CEC sorbed onto total suspended 297 solids (TSS) showed higher sensitivity if compared to the dissolved fraction sorbed to colloids, 298 mainly due to sedimentation parameters, in agreement with De Schepper et al. (2012). As to 299 conventional pollutants, ammonium, nitrite and nitrate were impacted by microbial growth 300 parameters, in agreement with Deksissa et al. (2004), while phosphorus was influenced by the 301 sorption rate and sedimentation parameters (Figure S2).

302 For the CSPM model, variations of CECs concentrations were influenced by several soil and plants 303 parameters (Figure S3), in agreement with previous modeling studies (Trapp, 2015) and 304 experimental data (Chen et al., 2013; Goldstein et al., 2014; Dodgen et al., 2015; Lamshoeft et al., 305 2018). Notably, the effect of the Arrhenius temperature correction coefficient on soil concentrations 306 (|PRCC $\mid>0.9)$ out-weighed the effect of the other parameters, as seen before (Legind et al., 2011). 307 Predicted concentrations of the weakly acidic DCF showed considerable sensitivity to internal plant $308 \mathrm{pH}$, which was further assessed.

\subsection{Fate analysis}

\section{$311 \quad$ 3.2.1 Surface water channel}

312 Verification of IUWS_MP for conventional pollutants was adequate for the intended purpose, 313 showing predicted concentrations in agreement with the measurements $(\leq 0.75 \log$ units $)$ and being 314 able to follow seasonal trends (Figure S4).

315 Along the water channel, model predictions (Figure 2 and Figures S5-14) showed that all the 316 investigated CECs were almost entirely found as dissolved in the water phase $(\sim 98 \%$ of the load 317 released from the WWTP). The only exception was CLA, for which the fractions on colloids and 
TSS were, on average, equal to $6 \%$ and $17 \%$ of the total mass (Figure 2c). Most of the simulated

319 CECs have lower sorption affinity than CLA $\left(\log K_{o w}=3.2\right)$, or they were negatively charged at the measured $\mathrm{pH}$ (i.e. electrical repulsion). These results were in good agreements with the 321 measurements in the Ebro river (Ferreira da Silva et al., 2011), where most of the CECs were found 322 as predominantly dissolved $(84 \%, 87 \%, 95 \%, 95 \%, 95 \%$ of the total mass for DCF, CLA, PAR, 323 CBZ and IBU, respectively). The width of concentration prediction bounds (about $\pm 200 \%$ of the 324 median) was mainly explained by the propagation of the uncertainties associated to the initial 325 concentrations of CECs in RWW and by degradation rates. Low variation in predicted concentrations ( $\sim 0.3 \mathrm{log}$ units) resulted from the propagation of uncertainties of conventional 327 pollutant parameters.

328 The temporal dynamics of predicted concentrations followed different daily and/or seasonal 329 patterns depending on the simulated CEC. For example, photodegradation caused an important 330 reduction in concentrations for DCF (52-89\%) and FUR (25-87\%) between night and day time, in 331 agreement with the findings of Hanamoto et al. (2013). Predicted DCF concentrations during day 332 time were also confirmed by the available measurements (Figure 2a). Photodegradation and 333 biodegradation also caused seasonal patterns with the lowest concentrations during June, July and 334 August (Figure 2a and 2b), when temperature and sunlight irradiation reached their maximum 335 values $\left(22-25^{\circ} \mathrm{C}\right.$ and up to $900 \mathrm{~W} \mathrm{~m}^{-2}$, respectively). A considerable reduction was observed in 336 summer months, as compared to December, for DCF (30-41\%; summer median: 204-244 ng L ${ }^{-1}$ ), 337 and FUR (49-72\%; summer median: 49.4-90.6 $\mathrm{ng} \mathrm{L}^{-1}$ ). Moreover, when rice was cultivated, median 338 concentrations of DCF and FUR were 16\% and 67\% lower than when winter wheat was cultivated 339 (orange and red lines in Figure 2). In fact, a high water withdrawal for rice cultivation led to a 340 reduction of the water level and thus enhancing photodegradation and sedimentation since rates of 341 these two processes are inversely proportional to the water depth (Schwarzenbach, 2003). 
342 Due to the low tendency to photodegrade (median $k_{\text {pho,nearsurf }} \leq 23.1 \mathrm{~d}^{-1}$ ) and the overall slow

343 biodegradation in water (median $\mathrm{k}_{\text {bio, water }} \leq 0.32 \mathrm{~d}^{-1}$ ), the other CECs showed smaller daily

344 fluctuations (intra-day variation: $\leq 10 \%$ ), seasonal trends (reduction in summer months compared

345 to December: $\leq 11 \%$ ) and variations due to water withdrawal (concentration decrease during rice

346 cultivation: $\leq 4 \%$ ) (see Figures S5-S14).
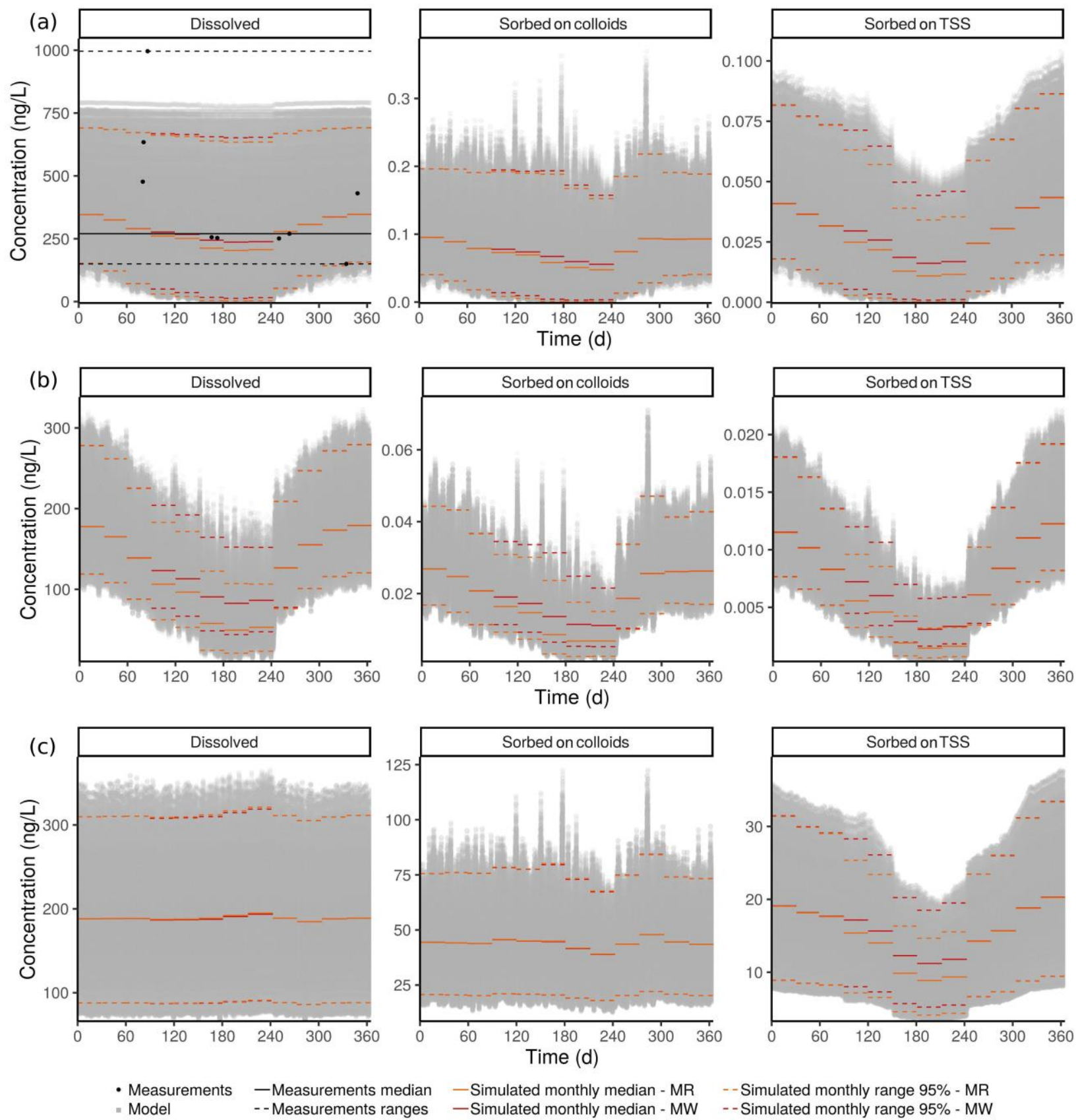

- Model

- Measurements ranges

- Simulated monthly median - MR

- - Simulated monthly range 95\% - MR

--Simulated monthly range $95 \%$ - MW

348 Figure 2. Annual variation (from January $1^{\text {st }}$ to December $31^{\text {st }}$ ) of daytime DCF (a), FUR (b), CLA

349 (c) concentrations at the end of the channel. 
351 Predicted attenuation rates were in good agreement with literature data (Figure S15), with slight underestimation ( $\leq 1$ order of magnitude). Differences might be due to the biofilm growth on submerged vegetation and sediment surface (Winkler et al., 2001; Sabaliunas et al., 2003; Kunkel 354 and Radke, 2011; Writer et al., 2013), that enhances attenuation processes with respect to 355 biodegradability processes accounted by our model.

356 Median attenuation rates varied throughout the year up to one order of magnitude due to different 357 environmental conditions (temperature, sunlight intensity and water depth), with predicted 358 maximum and minimum rates during July and December, respectively. Due to low CLA 359 degradation (median $\mathrm{k}_{\text {pho, nearsurf }}=0.17 \mathrm{~d}^{-1}$, median $\mathrm{k}_{\text {bio, water }}=3.85 \mathrm{E}^{-02} \mathrm{~d}^{-1}$ ), CLA attenuation rate 360 variations were mostly caused by sedimentation, which was enhanced by the lower summer water 361 depth, in agreement with Castiglioni et al. (2006). Similar seasonal variations of the attenuation 362 rates were also observed by Matamoros et al. (2017) and Labadie and Budzinski (2005).

\subsubsection{Crops}

365 In Figure $3 \mathrm{a}$ we report $\mathrm{BCF}_{\max }$ predictions for three $\mathrm{CECs}$ in different plant compartments, where 366 the maximum simulated soil concentration is used for normalization (see Figures S16-S19 for the $367 \mathrm{BCF}_{\max }$ calculated with maximum soil concentrations for all the other CECs). Figure 3b-c presents $368 \mathrm{BCF}_{\text {median }}$ values for fruits and leaves of the investigated crops based on the simulated median soil 369 concentration, given the larger data availability for plausibility check (see Figures S16-S19 for roots 370 and stems $\mathrm{BCFs}_{\text {median}}$ ). Box-plots were obtained by aggregating BCFs based on crop type (i.e. 371 maize, rice, ryegrass and wheat), and resulting ranges (i.e. width of the whiskers) included both variability (of CEC concentrations in the irrigation water, soil $\mathrm{pH}$ and soil organic content SOM)

373 and uncertainty of model input. 
374 Within crops (Figure 3a), predicted results for weakly acidic CECs, such as DCF, PFOA, FUR and 375 IBU, mainly show accumulation in roots, which can be partly attributed to phloem translocation. For these CECs, a considerable BCF variation (more than factor 100) was generally obtained. This could be attributed to $\mathrm{pH}$ variability within the plant cell organs (Vreugdenhil and Koot-Gronsveld, 1989; Felle, 2001), which can strongly affect speciation of ionizable CECs and, consequently, the extent of CECs adsorption and translocation within the plant (Trapp, 2004). Moreover, large BCF variations for PFOA and PFOS were also associated to $\log \mathrm{K}_{\mathrm{ow}}$ and $\mathrm{K}_{\mathrm{HSA}}$ uncertainty, which affect in-plant translocation and in-soil bioavailability (Trapp, 2009). TCS also showed maximum accumulation in roots, but mainly due to its high lipophilicity, which limits partitioning into xylem (Hsu et al., 1990). Conversely, neutral and hydrophilic CECs, such as CBZ, translocated upwards through the xylem to the leaves (Collins et al., 2006; Miller et al., 2016), where they showed the highest accumulation. In this case, variations of BCF were mainly caused by SOM variability, which influenced sorption of CECs in neutral form, such as estrogens (E1, E2 and EE2), TCS, PAR and CBZ (Goldstein et al., 2014), affecting bioavailability and uptake. SMX presented a more uniform accumulation among the plant organs due to both high phloem and xylem mobility (Kleier and Hsu, 1996; Goldstein et al., 2014). Regardless of the type of CEC, rice was generally the crop showing the highest uptake (Figure 3a), given that the irrigation system constantly floods the crop over the irrigational period, thus enhancing CECs loading. Conversely, the other crops were intermittently irrigated, and degradation and growth dilution lower uptake between irrigation events.

394 Box-plot medians (Figure 3b-c) were generally close (within 1 order of magnitude) to 395 measurements, while for estrogens and PAR few to no measurements were available. Conversely, 396 CBZ, TCS and SMX (having the highest data availability) showed measured values overall lower

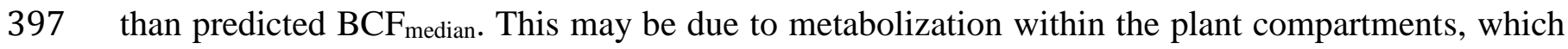
398 has been experimentally observed for CBZ in leaves (Riemenschneider et al., 2016; Goldstein et al., 
2014; Malchi et al., 2014), for TCS in roots (Macherius et al., 2012) and for SMX (Dodgen et al., 400 2013; Bircher et al., 2015; He et al., 2017; Li et al., 2018). In the model, metabolization within 401 plants was assumed negligible since no kinetic data are available within the existing literature to account for such process. The approach used with respect to in-plant metabolism represents a realistic worst-case scenario. Moreover, in-plant metabolism does not always lead to degradation of 404 the chemical but may lead to the formation of (i) conjugated metabolites that are prone to be 405 transformed back to their parent analogue (Macherius et al., 2012); (ii) other metabolites that may 406 be as hazardous as their respective parent (e.g., the case of carbamazepine metabolites; Malchi et 407 al., 2015).

408 BCF calculation was highly affected by in-soil degradation, since it increases the differences 409 between maximum and median soil concentration (hence, the difference between $\mathrm{BCF}_{\max }$ and $\left.410 \mathrm{BCF}_{\text {median}}\right)$. In particular, $\mathrm{BCF}_{\text {median }}$ variation for estrogens was the most affected $(\geq 2$ orders of 411 magnitude) by in-soil degradation rates. The effect was more pronounced for maize, as the longer 412 time between irrigation events allows for larger variations of the median soil concentration than for 413 other crops. Overall, these results further confirm the need for a standard methodology for BCF 414 calculation to allow for inter-study comparison of empirical results.

415 The model also predicted mass loss above $10^{-4} \mathrm{mg} \mathrm{m}^{-2}$ season ${ }^{-1}$ from soil to groundwater for CBZ, 416 SMX, IBU, PFOS and PFOA (Figure S20), in agreement with the high GW concentrations 417 measured in the area (Castiglioni et al., 2018b). Losses to groundwater were also predicted for DCF 418 and FUR, while measurements were below detection limits, possibly due to further degradation 419 outside the model boundary. Castiglioni et al. (2018b) also found traces of CLA and TCS in the 420 groundwater, in disagreement with model predictions that showed almost complete accumulation in 421 the surface soil layers, as confirmed by Chen et al. (2013) and Xu et al. (2009). The chemicals 422 might stem from other sources (e.g. house imhoff tanks located in rural area) or reach groundwater 423 by 

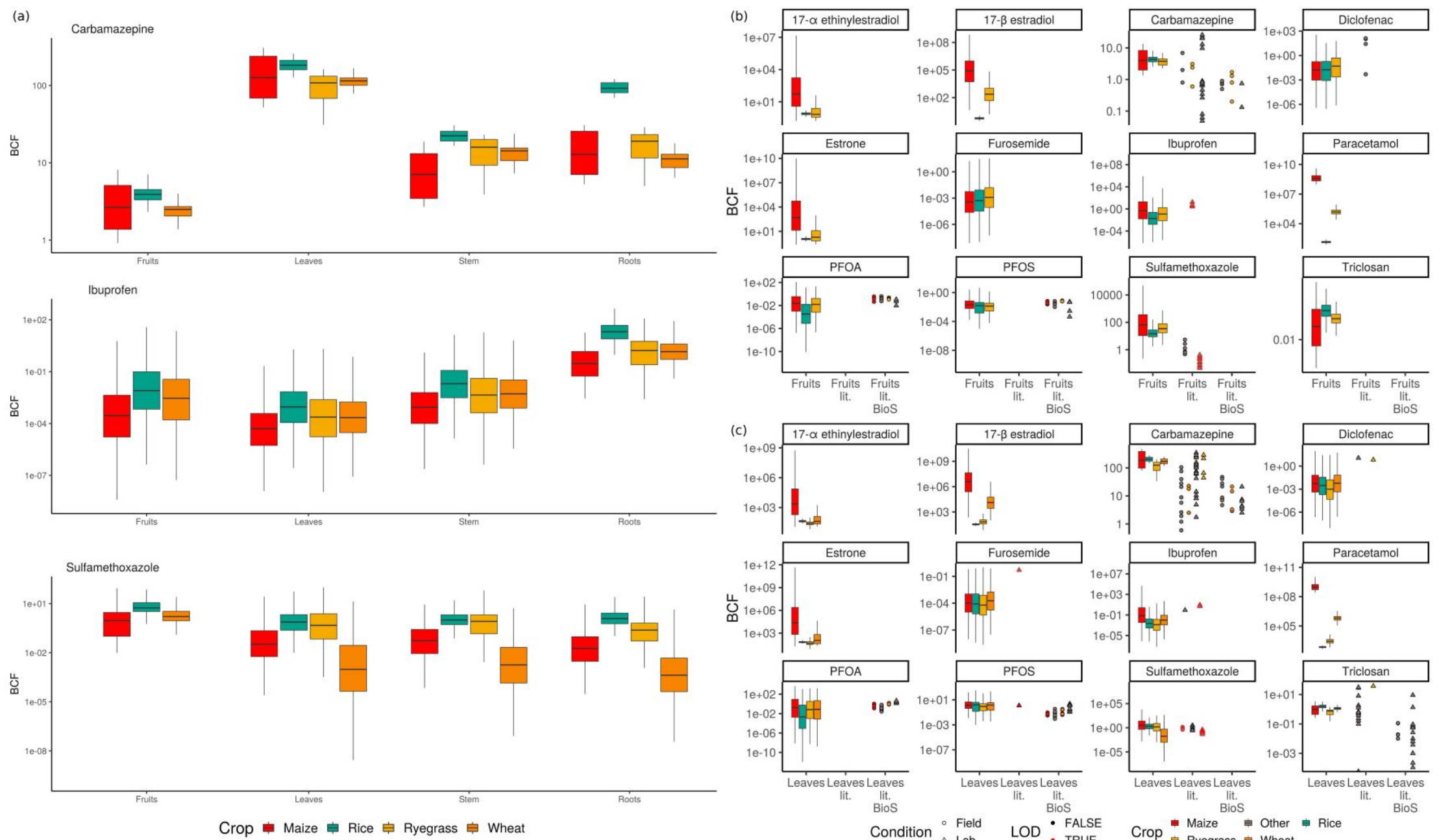

Fruils

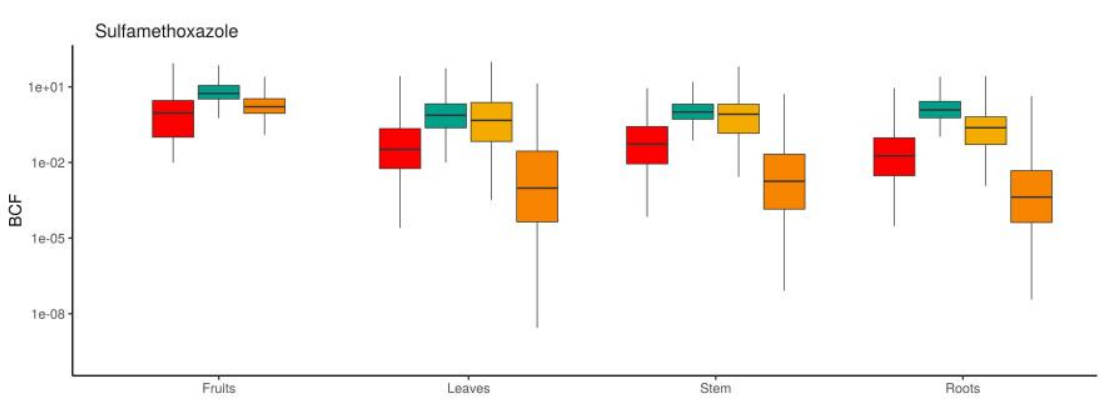

Crop Maize Rice 追 Ryegrass 追 Wheat

Condition Field LOD: FALSE

Crop Maize Other Mice

Figure 3. (a) Bioconcentration factors (BCFs, $g_{d w} / g_{d w}$ ) for CBZ, IBU and SMX in different crops and soil types. BCFs were calculated with respect to maximum soil concentrations (COLOR FIGURE). $(b, c)$ Fruit and leaf BCFs $\left(g_{d w} / g_{d w}\right)$ for all evaluated CECs in silage maize, winter wheat and rice in different soil types, and comparison with literature values (lit.). BCFs were calculated with respect to median soil concentrations. BioS indicates experimental studies conducted with the use of biosolids. Red borders indicate the use of a LOD value in the calculations. Refs: Bizkarguenaga et al. (2016), Blaine et al. (2013), Carter et al. (2014), Christou et al. (2017), Fu et al. (2016), Goldstein et al. (2014), Hurtado et al. (2017), Malchi et al. (2014), Mordechay et al. (2018), Navarro et al. (2017), Pannu et al. (2012), Shenker et al. (2011), Wen et al. (2014), Winker et al. (2010), Wu et al. (2010, 2012), Yager

al.

(2014),

Yoo

et

al.
(2011). 


\subsection{Risk assessment}

\subsubsection{Ecological risk}

434 Three estrogens (E1, E2 and EE2), two antibiotics (SMX and CLA), one non-steroidal anti435 inflammatory drug (IBU) and one antiseptic (TCS) showed RQmedian above the alert thresholds at 436 least once over the 1-year simulation. EE2 displayed the highest risk both in terms of magnitude 437 and frequency of exceedance, with a daily median concentration always above the PNEC (RQmedian 438 27), and a maximum concentration during winter corresponding to a $R Q_{\max }$ of 46 . Predicted $439 \mathrm{RQ}_{\text {median }}$ for E2, CLA and TCS were approximately 1.5, with an average monthly frequency of 440 exceeding the corresponding PNECs of $0.95,0.79$ and 0.77 , respectively. IBU, E1 and SMX 441 showed $R Q_{\text {median }}$ below 1, although a non-negligible ecological risk ( $R Q_{\text {max }}$ ranging between 0.15 442 and 0.45) was shown. Other investigated CECs had an RQ below 0.1, showing low or negligible 443 ecological risk (see Table S22). These results, in good agreement with what found by Riva et al. 444 (2019) in the surrounding area, highlight that certain CECs may negatively affect aquatic organisms 445 at a medium distance (approximately $12 \mathrm{~km}$ ) from the WWTP.

\section{$447 \quad$ 3.3.2 Human health risk from dietary uptake}

448 The estimated consumption of rice and wheat required to exceed TTCs (Table S23) showed 449 unrealistic values ( $>2 \mathrm{~kg} / \mathrm{d}$ per person) for all the CECs but SMX. For this compound a 450 consumption of $10 \mathrm{~g} / \mathrm{d}$ and $50 \mathrm{~g} / \mathrm{d}$ (considering the $97.5^{\text {th }}$ rice concentration percentile) might imply 451 potential genotoxic effects (Malchi et al., 2015) on infants and adults, respectively. Conversely, 452 SMX had an HQ below the alert threshold of 0.1 in accordance with the work of Christou et al. 453 (2017). Consequently, experimental measurements should be performed in rice to clarify a possible 454 risk related to SMX. The calculated negligible human health risk is in good agreement with the 455 findings of Malchi et al. (2014) and Riemenschneider et al. (2016). 
456 As for the predicted risk by the HQ approach (Table 1), results indicated negligible risk for all the 457 CECs, although an HQ (infants) of 0.3 was calculated for EE2. A comparison with the TTC could 458 not be done, since this latter approach is not valid for classes of compounds such as estrones (Kroes 459 et al., 2004).

460 To conclude, the HI value (sum of all individual HQs, see Table 1) was below 1, showing no 461 potential risk for human health from the investigated CECs. Moreover, the risk from indirect 462 exposure (possible biotransfer of CECs from forage to milk and beef and, subsequently to humans) 463 was not quantified since available empirical models (Travis and Arms, 1988; Hendriks et al., 2007) 464 failed to properly describe fate of ionisable compounds and were not validated for the CECs here 465 considered. Mechanistic models (Rosenbaum et al., 2009; Trapp et al., 2008) predict 466 bioaccumulation in milk and meat solely for chemicals with strong partitioning into lipids, which is 467 not the case for the investigated compounds. 
470 Table 1. HQs and HIs for crops irrigated with water withdrawn at the end of the channel. P97.5

471 stands for values calculated with the $97.5^{\text {th }}$ percentile CEC concentration.

\begin{tabular}{|c|c|c|c|c|c|c|}
\hline \multirow{2}{*}{ ECs } & \multicolumn{2}{|c|}{ Rice } & \multicolumn{2}{|c|}{ Wheat } & \multicolumn{2}{|c|}{ Total } \\
\hline & Median & P97.5 & Median & P97.5 & Median & P97.5 \\
\hline \multicolumn{7}{|l|}{ Infants } \\
\hline SMX & $2.94 \mathrm{E}-03$ & 2.03E-02 & $1.86 \mathrm{E}-04$ & $1.58 \mathrm{E}-03$ & $3.12 \mathrm{E}-03$ & $2.19 \mathrm{E}-02$ \\
\hline DCF & $2.66 \mathrm{E}-06$ & $6.35 \mathrm{E}-04$ & $6.14 \mathrm{E}-08$ & $1.26 \mathrm{E}-05$ & 2.72E-06 & $6.48 \mathrm{E}-04$ \\
\hline IBU & $1.12 \mathrm{E}-09$ & $5.27 \mathrm{E}-07$ & $1.21 \mathrm{E}-10$ & $5.94 \mathrm{E}-08$ & $1.24 \mathrm{E}-09$ & $5.86 \mathrm{E}-07$ \\
\hline PAR & $7.12 \mathrm{E}-07$ & $1.05 \mathrm{E}-06$ & 5.64E-08 & $9.08 \mathrm{E}-08$ & 7.69E-07 & $1.14 \mathrm{E}-06$ \\
\hline $\mathrm{CBZ}$ & $2.62 \mathrm{E}-03$ & $3.91 \mathrm{E}-03$ & $2.21 \mathrm{E}-03$ & $2.80 \mathrm{E}-03$ & 4.84E-03 & $6.71 \mathrm{E}-03$ \\
\hline FUR & 5.37E-08 & 8.49E-05 & $1.25 \mathrm{E}-07$ & $9.82 \mathrm{E}-05$ & 1.79E-07 & $1.83 \mathrm{E}-04$ \\
\hline EE2 & $2.77 \mathrm{E}-02$ & $2.57 \mathrm{E}-01$ & $1.95 \mathrm{E}-03$ & $3.85 \mathrm{E}-02$ & 2.97E-02 & $2.95 \mathrm{E}-01$ \\
\hline E2 & $1.07 \mathrm{E}-05$ & $2.53 \mathrm{E}-05$ & $8.72 \mathrm{E}-07$ & $2.02 \mathrm{E}-06$ & $1.15 \mathrm{E}-05$ & $2.73 \mathrm{E}-05$ \\
\hline E1 & $5.23 \mathrm{E}-04$ & 4.82E-03 & $4.06 \mathrm{E}-05$ & $7.80 \mathrm{E}-04$ & $5.63 \mathrm{E}-04$ & $5.60 \mathrm{E}-03$ \\
\hline PFOS & $6.98 \mathrm{E}-06$ & $2.75 \mathrm{E}-04$ & $5.44 \mathrm{E}-06$ & $1.24 \mathrm{E}-04$ & $1.24 \mathrm{E}-05$ & $4.00 \mathrm{E}-04$ \\
\hline PFOA & $2.23 \mathrm{E}-08$ & $1.22 \mathrm{E}-04$ & $1.17 \mathrm{E}-06$ & $2.66 \mathrm{E}-04$ & 1.19E-06 & $3.88 \mathrm{E}-04$ \\
\hline TCS & $6.19 \mathrm{E}-09$ & $1.79 \mathrm{E}-08$ & 2.57E-09 & $1.04 \mathrm{E}-08$ & $8.76 \mathrm{E}-09$ & $2.83 \mathrm{E}-08$ \\
\hline
\end{tabular}

\begin{tabular}{lllllll} 
Adults & \multicolumn{7}{l}{} \\
\hline SMX & $4.45 \mathrm{E}-04$ & $3.08 \mathrm{E}-03$ & $8.88 \mathrm{E}-05$ & $7.52 \mathrm{E}-04$ & $5.34 \mathrm{E}-04$ & $3.83 \mathrm{E}-03$ \\
DCF & $4.03 \mathrm{E}-07$ & $9.63 \mathrm{E}-05$ & $2.93 \mathrm{E}-08$ & $6.03 \mathrm{E}-06$ & $4.33 \mathrm{E}-07$ & $1.02 \mathrm{E}-04$ \\
IBU & $1.70 \mathrm{E}-10$ & $7.99 \mathrm{E}-08$ & $2.93 \mathrm{E}-08$ & $6.03 \mathrm{E}-06$ & $2.27 \mathrm{E}-10$ & $1.80 \mathrm{E}-07$ \\
PAR & $1.08 \mathrm{E}-07$ & $1.59 \mathrm{E}-07$ & $2.69 \mathrm{E}-08$ & $4.33 \mathrm{E}-08$ & $1.35 \mathrm{E}-07$ & $2.20 \mathrm{E}-07$ \\
CBZ & $3.98 \mathrm{E}-04$ & $5.93 \mathrm{E}-04$ & $1.06 \mathrm{E}-03$ & $1.33 \mathrm{E}-03$ & $1.45 \mathrm{E}-03$ & $1.93 \mathrm{E}-03$ \\
FUR & $8.14 \mathrm{E}-09$ & $1.29 \mathrm{E}-05$ & $5.96 \mathrm{E}-08$ & $4.69 \mathrm{E}-05$ & $6.78 \mathrm{E}-08$ & $5.97 \mathrm{E}-05$ \\
EE2 & $4.20 \mathrm{E}-03$ & $3.89 \mathrm{E}-02$ & $9.32 \mathrm{E}-04$ & $1.84 \mathrm{E}-02$ & $5.13 \mathrm{E}-03$ & $5.73 \mathrm{E}-02$ \\
E2 & $1.62 \mathrm{E}-06$ & $3.84 \mathrm{E}-06$ & $4.16 \mathrm{E}-07$ & $9.63 \mathrm{E}-07$ & $2.03 \mathrm{E}-06$ & $4.80 \mathrm{E}-06$ \\
E1 & $7.93 \mathrm{E}-05$ & $7.30 \mathrm{E}-04$ & $1.94 \mathrm{E}-05$ & $3.72 \mathrm{E}-04$ & $9.86 \mathrm{E}-05$ & $1.10 \mathrm{E}-03$ \\
PFOS & $1.06 \mathrm{E}-06$ & $1.31 \mathrm{E}-04$ & $2.60 \mathrm{E}-06$ & $5.94 \mathrm{E}-05$ & $3.65 \mathrm{E}-06$ & $1.90 \mathrm{E}-04$ \\
PFOA & $3.38 \mathrm{E}-09$ & $1.85 \mathrm{E}-05$ & $5.58 \mathrm{E}-07$ & $1.27 \mathrm{E}-04$ & $5.62 \mathrm{E}-07$ & $1.46 \mathrm{E}-04$ \\
TCS & $9.38 \mathrm{E}-10$ & $2.71 \mathrm{E}-09$ & $1.23 \mathrm{E}-09$ & $4.96 \mathrm{E}-09$ & $2.17 \mathrm{E}-09$ & $7.67 \mathrm{E}-09$ \\
\hline \multicolumn{7}{c}{ Hazard Index } \\
\hline
\end{tabular}

\section{$473 \quad 3.4$ Risk management strategies}

474 The adoption of a more efficient irrigation system (i.e. sprinklers) led to a calculated reduction of

475 the human health risk due to the lower CECs load that reach the crops. Particularly, median HQs for 
infants decreased by $25 \%$ for EE2 and SMX. In the model simulations, direct deposition of

477 chemicals on leaf surfaces due to sprinkling has not been considered and may lead to an additional uptake of chemicals via this pathway, while significant uptake into grains via surface deposition is unlikely. However, weak acids could reach the grains by phloem transport. We are not aware of studies addressing this process. On the other hand, the adoption of a crop-drying stage before rice harvest did not show any substantial reduction $(<2 \%)$ in the median rice concentrations of EE2 (from $3.71 \cdot 10^{-4} \mathrm{ng} / \mathrm{g}_{\mathrm{dw}}$ to $3.65 \cdot 10^{-4} \mathrm{ng} / \mathrm{g}_{\mathrm{dw}}$ ) and $\mathrm{SMX}$ (from $5.21 \mathrm{E}^{-01} \mathrm{ng} / \mathrm{g}_{\mathrm{dw}}$ to $5.12 \mathrm{E}^{-01} \mathrm{ng} / \mathrm{g}_{\mathrm{dw}}$ ). In fact, at the later stages of crop growth the transpiration rate is minimum (Hidayati et al., 2016), consequently resulting in limiting the predicted CECs uptake during this stage. To best of our knowledge no experimental studies compared the CECs uptake under different irrigation systems preventing further verification of the model results.

Although not explicitly designed to remove CECs, the existing WWTP showed to be crucial for guaranteeing human health safety. In the scenario where the WWTP was absent, only few CECs (PFOS, PFOA, DCF, FUR and CBZ) had a HQ median risk below 0.1, while it was substantially above 1 for all the other CECs. For example, HQmedian of TCS increased from 1.43 to 429, reaching in the worst-case scenario an $\mathrm{HQ}_{\max }$ of 842 . Predicted rice concentrations increased up to 3 orders of magnitude, especially for TCS, IBU, E1 and PAR, which are efficiently removed (>99\%) by the WWTP (Castiglioni et al., 2018b). These results were in agreement with the work of Goldstein et al. (2014) and Wu et al. (2014), in which higher CECs concentrations in TWW led to higher accumulation in crops. The risk for infants associated to SMX and PAR (considering the 97.5 ${ }^{\text {th }}$ percentile of the concentration in rice) showed a required ingestion to exceed TTC lower than $1 \mathrm{~g} \mathrm{~d}^{-}$ ${ }^{1}$ and the HQs of E1, EE2 and SMX were 0.34, 0.26 and 0.33 , respectively. Median and $97.5^{\text {th }}$ 498 percentile for infants HIs increased up to 8 times, reaching values of 0.27 and 0.95 . respectively. 499 These results further indicate that irrigation with untreated wastewater requires specific attention 500 when considering the risk posed by CECs. 


\section{Conclusions}

503 This study proposed a new integrated model for simulating the fate of different contaminants of 504 emerging concern under dynamic conditions when reclaimed wastewater is reused for irrigation 505 purposes. By extending and integrating existing fate models, the model showed capability and 506 flexibility in describing the fate of 13 contaminants, covering a wide range of physicochemical 507 properties, across different compartments and over long time intervals.

508 Model predictions for contaminant occurrence in irrigation water and crops were generally verified 509 with measured data, thus allowing for the evaluation of ecological and human health risk posed by 510 wastewater discharge and reuse. Although dependent on the approach used, sulfamethoxazole and 511 17 $\alpha$-ethinylestradiol were associated to potential health risk from dietary intake of irrigated crops, 512 particularly rice. While the existing wastewater treatment plant contributes significantly to reduce 513 the overall risk, further reductions can be obtained by adopting more efficient irrigation practices.

514 Overall the proposed integrated approach represents a valuable decision support tool for assessing 515 the safety of reclaimed wastewater reuse practices within the circular economy, particularly when 516 considering recent developments in the regulation (EC, 2018).

\section{Acknowledgments}

519 The authors would like to acknowledge the COST Action ES1403 NEREUS "New and emerging 520 challenges and opportunities in wastewater reuse", supported by COST (European Cooperation in 521 Science and Technology, www.cost.eu), for enabling the collaboration among the authors of the 522 paper. 


\section{References}

525 Asano, T. (2002). Water from (waste)water - the dependable water resource. Water Science and 526 Technology, 45(8):23-33.

527 Bach, P. M., Rauch, W., Mikkelsen, P. S., McCarthy, D. T., and Deletic, A. (2014). A critical 528 review of integrated urban water modelling: Urban drainage and beyond. Environmental 529 Modelling and Software, 54(4):88-107.

530 Benedetti, L., Meirlaen, J., Sforzi, F., Facchi, A., Gandolfi, C., \& Vanrolleghem, P. A. (2004). 531 Dynamic integrated modelling: a case study on the river Lambro. Novatech 2004, 1-8.

532 Borrelli, L., Castelli, F., Ceotto, E., Cabassi, G., \& Tomasoni, C. (2014). Maize grain and silage 533 yield and yield stability in a long-term cropping system experiment in northern italy. European $534 \quad$ Journal of Agronomy, 55, 12-19.

535 Brouwer, C., Hoevenaars, J.P.M. \& Van Bosch, B.E., (1992) Scheme Irrigation Water Needs and $536 \quad$ Supply. Rome, Italy: FAO.

537 Brouwer, C., Prins, K., \& Heibloem, M. (1989). Irrigation Water Management: Irrigation $538 \quad$ Scheduling. Rome, Italy: FAO.

539 Castiglioni, S., Bagnati, R., Fanelli, R., Pomati, F., Calamari, D., \& Zuccato, E. (2006). Removal of 540 pharmaceuticals in sewage treatment plants in Italy. Environmental Science and Technology, $541 \quad 40(1), 357-363$.

542 Castiglioni, S., Davoli, E., Riva, F., Palmiotto, M., Camporini, P., Manenti, A., \& Zuccato, E. 543 (2018a). Data on occurrence and fate of emerging contaminants in a urbanised area. Data in $544 \quad$ Brief, 17, 533-543.

545 Castiglioni, S., Davoli, E., Riva, F., Palmiotto, M., Camporini, P., Manenti, A., \& Zuccato, E. 546 (2018b). Mass balance of emerging contaminants in the water cycle of a highly urbanized and 547 industrialized area of Italy. Water Research, 131:287-298. 
Chen, W., Xu, J., Lu, S., Jiao, W., Wu, L., \& Chang, A. C. (2013). Fates and transport of PPCPs in

549 soil receiving reclaimed water irrigation. Chemosphere, 93(10), 2621-2630.

550 Christou, A., Agüera, A., Bayona, J.M., Cytryn, E., Fotopoulos, V., Lambropoulou, D., Manaia, 551 C.M., Michael, C., Revitt, M., Schröder, P., Fatta-Kassinos, D. (2017). The potential 552 implications of reclaimed wastewater reuse for irrigation on the agricultural environment: The 553 knowns and unknowns of the fate of antibiotics and antibiotic resistant bacteria and resistance 554 genes - A review. Water Res. 123:448-467.

555 Collins, C., Fryer, M., and Grosso, A. (2006). Plant uptake of non-ionic organic chemicals. 556 Environmental Science and Technology, 40(1):45-52.

557 COM (2015) 614 Closing the loop- An EU action plan for the Circular Economy. Communication 558 from the Commission to the European Parliament, the Council, the European Economic and 559 Social Committee and the Committee of the Regions. European Commission, Brussels, Belgium. 560 COM (2018) 337 Proposal for a REGULATION OF THE EUROPEAN PARLIAMENT AND OF 561 THE COUNCIL on minimum requirements for water reuse. Proposal from the Commission to 562 the European Parliament, the Council, the European Economic and Social Committee and the 563 Committee of the Regions. European Commission, Brussels, Belgium.

564 Daughton, C. G. and Ternes, T. A. (1999). Pharmaceuticals and personal care products in the 565 environment: agents of subtle change? Environmental Health Perspectives, 107(suppl 6):907566938.

567 De Keyser, W., Gevaert, V., Verdonck, F., Nopens, I., De Baets, B., Vanrolleghem, P.A., 568 Mikkelsen, P.S., Benedetti, L., (2010). Combining multimedia models with integrated urban 569 water system models for micropollutants. Water Sci. Technol. 62, 1614-1622.

570 De Schepper, V. C. J., Holvoet, K. M. A., Benedetti, L., Seuntjens, P., \& Vanrolleghem, P. A. 571 (2012). Extension of the River Water Quality Model No. 1 with the fate of pesticides. Journal of $572 \quad$ Hydroinformatics, 14(1), 48-64. 
573 Deksissa, T., Meirlaen, J., Ashton, P. J., \& Vanrolleghem, P. A. (2004). Simplifying dynamic river 574 water quality modelling: A case study of inorganic nitrogen dynamics in the Crocodile River 575 (South Africa). Water, Air, and Soil Pollution, 155(1-4), 303-320.

576 Ding, Y., Hayes, M. J., and Widhalm, M. (2011). Measuring economic impacts of drought: A 577 review and discussion. Disaster Prevention and Management, 20(4):434-446.

578 Dodgen, L. K., Ueda, A., Wu, X., Parker, D. R., and Gan, J. (2015). Effect of transpiration on plant 579 accumulation and translocation of PPCP/EDCs. Environmental Pollution, 198:144-153.

580 Dudley, S., Sun, C., Jiang, J., \& Gan, J. (2018). Metabolism of sulfamethoxazole in Arabidopsis 581 thaliana cells and cucumber seedlings. Environmental Pollution, 242, 1748-1757.

582 Durán-Alvarez, J. C., Becerril-Bravo, E., Castro, V. S., Jiménez, B., and Gibson, R. (2009). The 583 analysis of a group of acidic pharmaceuticals, carbamazepine, and potential endocrine disrupting 584 compounds in wastewater irrigated soils by gas chromatography-mass spectrometry. Talanta, 585 78(3):1159-1166.

586 EC (European Commission), 2018. Proposal for a Regulation of the European Parliament and of the $587 \quad$ Council on minimum requirements for water reuse. Brussels, $28^{\text {th }}$ May 2018.

588 EFSA Scientific Commitee. (2012). Guidance on selected default values to be used by the EFSA 589 Scientific Committee, Scientific Panels and Units in the absence of actual measured data. EFSA $590 \quad$ Journal, 10(3), 2579.

591 Evans, R. M., Scholze, M., \& Kortenkamp, A. (2015). Examining the feasibility of mixture risk 592 assessment: A case study using a tiered approach with data of 67 pesticides from the Joint 593 FAO/WHO Meeting on Pesticide Residues (JMPR). Food and Chemical Toxicology, 84, 260594269.

595 Felle, H. H. (2001). pH: Signal and messenger in plant cells. Plant Biology, 3(6), 577-591. 
Ferreira da Silva, B., Jelic, A., López-Serna, R., Mozeto, A. A., Petrovic, M., \& Barceló, D. (2011). Occurrence and distribution of pharmaceuticals in surface water, suspended solids and sediments of the Ebro river basin, Spain. Chemosphere, 85(8), 1331-1339.

Franco, A., Struijs, J., Gouin, T., \& Price, O. R. (2013). Evolution of the sewage treatment plant model SimpleTreat: Applicability domain and data requirements. Integrated Environmental Assessment and Management, 9(4), 560-568. compounds in the REACH chemical space. International Journal of Life Cycle Assessment, $15(4), 321-325$.

Franco, A., Ferranti, A., Davidsen, C., \& Trapp, S. (2010). An unexpected challenge: Ionizable

Franco, A., \& Trapp, S. (2008). Estimation of the soil-water partition coefficient normalized to organic carbon for ionizable organic chemicals. Environ. Toxicol. Chem. 27, 1995-2004.
613 Wastewater-Borne Pharmaceuticals by Vegetables. Environmental Science and Technology, $614 \quad 48: 5593-5600$

615 Gonzalez-Garcia, M., Fernandez-Lopez, C., Polesel, F., Trapp, S. (2019). Predicting the uptake of 616 emerging organic contaminants in vegetables irrigated with treated wastewater - Implications for 617 food safety assessment. Environ. Res. 172, 175-181.

618 Gosling, S. N. and Arnell, N. W. (2016). A global assessment of the impact of climate change on 619 water scarcity. Climatic Change, 134(3), 371-385. 
620 Hanamoto, S., Nakada, N., Yamashita, N., \& Tanaka, H. (2013). Modeling the photochemical 621 attenuation of down-the-drain chemicals during river transport by stochastic methods and field 622

624 Hendriks, A. J., Smítková, H., \& Huijbregts, M. A. J. (2007). A new twist on an old regression: 625 Transfer of chemicals to beef and milk in human and ecological risk assessment. Chemosphere, $62670(1), 46-56$.

627 Hernando, M. D., Mezcua, M., Fernández-Alba, A. R., \& Barceló, D. (2006). Environmental risk 628 assessment of pharmaceutical residues in wastewater effluents, surface waters and sediments. 629 Talanta, 69(2 SPEC. ISS.), 334-342.

630 Hidayati, N., Triadiati, \& Anas, I. (2016). Photosynthesis and Transpiration Rates of Rice 631 Cultivated Under the System of Rice Intensification and the Effects on Growth and Yield. 632 HAYATI Journal of Biosciences, 23(2), 67-72.

633 Hsu, F. C., Marxmiller, R. L., \& Yang, A. Y. S. (1990). Study of Root Uptake and Xylem 634 Translocation of Cinmethylin and Related Compounds in Detopped Soybean Roots Using a 635 Pressure Chamber Technique. Plant Physiology, 93(4), 1573-1578.

636 IPCC (2014). Climate Change 2014: Impacts, Adaptation, and Vulnerability. Part A: Global and 637 Sectoral Aspects. Contribution of Working Group II to the Fifth Assessment Report of the 638 Intergovernmental Panel on Climate Change. Cambridge University Press, Cambridge, United 639 Kingdom and New York, NY, USA.

640 Kleier, D. A., \& Hsu, F. C. (1996). Phloem Mobility of Xenobiotics. VII. The Design of Phloem 641 Systemic Pesticides. Weed Science, 44(3), 749-756.

642 Kroes, R., Renwick, A. ., Cheeseman, M., Kleiner, J., Mangelsdorf, I., Piersma, A., ... Würtzen, G. 643 (2004). Structure-based thresholds of toxicological concern (TTC): guidance for application to 644 substances present at low levels in the diet. Food and Chemical Toxicology, 42(1), 65-83. 
645 Kunkel, U., \& Radke, M. (2011). Reactive tracer test to evaluate the fate of pharmaceuticals in 646 rivers. Environmental Science and Technology, 45(15), 6296-6302.

647 Kuzmanovic, M., Banjac, Z., Ginebreda, A., Petrovic, M., \& Barcelo, D. (2013). Prioritization: 648 Selection of Environmentally Occurring Pharmaceuticals to Be Monitored. In M. Petrovic, D. 649 Barcelo, \& S. Pérez (Eds.), Comprehensive Analytical Chemistry (2nd ed., Vol. 62, pp. 71-90).

650 Labadie, P., \& Budzinski, H. (2005). Determination of steroidal hormone profiles along the Jalle 651 d'Eysines River (near Bordeaux, France). Environmental Science and Technology, 39(14), $652 \quad 5113-5120$.

653 Lamshoeft, M., Gao, Z., Resseler, H., Schriever, C., Sur, R., Sweeney, P., ... Reitz, M. U. (2018). 654 Evaluation of a novel test design to determine uptake of chemicals by plant roots. Science of the 655 Total Environment, 613-614, 10-19.

656 Lazarova, V. and Asano, T. (2013). Milestones in water reuse: main challenges, keys to success and 657 trends of development. An overview. In Lazarova, V., Asano, T., Bahri, A., and Anderson, J., 658 editors, “Milestones in Water Reuse”, pages 1-22.

659 Leclercq, C., Arcella, D., Piccinelli, R., Sette, S., \& Le Donne, C. (2009). The Italian National Food 660 Consumption Survey INRAN-SCAI 2005-06: main results in terms of food consumption. Public $661 \quad$ Health Nutrition, 12(12), 2504-2532.

662 Legind, C. N., Kennedy, C. M., Rein, A., Snyder, N., \& Trapp, S. (2011). Dynamic plant uptake 663 model applied for drip irrigation of an insecticide to pepper fruit plants. Pest Management $664 \quad$ Science, 67(5), 521-527.

665 Lesser, L. E., Mora, A., Moreau, C., Mahlknecht, J., Hernández-Antonio, A., Ramirrez, A. I., and 666 Barrios-Piña, H. (2018). Survey of 218 organic contaminants in groundwater derived from the 667 world's largest untreated wastewater irrigation system: Mezquital Valley, Mexico. Chemosphere, $668 \quad 198: 510-521$. 
Li, Y., Chuang, Y. H., Sallach, J. B., Zhang, W., Boyd, S. A., \& Li, H. (2018). Potential metabolism of pharmaceuticals in radish: Comparison of in vivo and in vitro exposure. Environmental Pollution, 242, 962-969.

Limmer, M. A., \& Burken, J. G. (2014). Plant Translocation of Organic Compounds: Molecular and Physicochemical Predictors. Environmental Science and Technology Letters, 1(2), 156-161.

Luo, Y., Guo, W., Ngo, H. H., Nghiem, L. D., Hai, F. I., Zhang, J., Liang, S., Wang, X. C. (2014). A review on the occurrence of micropollutants in the aquatic environment and their fate and removal during wastewater treatment. Science of the Total Environment, 473-474:619-641.

Macherius, A., Eggen, T., Lorenz, W. G., Reemtsma, T., Winkler, U., \& Moeder, M. (2012). Uptake of Galaxolide, Tonalide, and Triclosan by Carrot, Barley, and Meadow Fescue Plants. Journal of Agricultural and Food Chemistry, 60(32), 7785-7791.

Malchi, T., Maor, Y., \& Chefetz, B. (2015). Comments on "Human health risk assessment of pharmaceuticals and personal care products in plant tissue due to biosolids and manure amendments, and wastewater irrigation.” Environment International, 82, 110-112.

Malchi, T., Maor, Y., Tadmor, G., Shenker, M., \& Chefetz, B. (2014). Irrigation of Root Vegetables with Treated Wastewater: Evaluating Uptake of Pharmaceuticals and the Associated Human Health Risks. Environmental Science \& Technology, 48(16), 9325-9333.

Masseroni, D., Ricart, S., de Cartagena, F. R., Monserrat, J., Gonçalves, J. M., de Lima, I., ... Gandolfi, C. (2017). Prospects for improving gravity-fed surface irrigation systems in mediterranean european contexts. Water (Switzerland), 9(1), 20.

Miller, E. L., Nason, S. L., Karthikeyan, K. G., and Pedersen, J. A. (2016). Root Uptake of Pharmaceuticals and Personal Care Product Ingredients. Environmental Science and Technology, 50(2):525-541. 
Matamoros, V., \& Rodríguez, Y. (2017). Influence of seasonality and vegetation on the attenuation of emerging contaminants in wastewater effluent-dominated streams. A preliminary study. Chemosphere, 186, 269-277.

McArdell, C. S., Molnar, E., Suter, M. J. F., \& Giger, W. (2003). Occurrence and Fate of Macrolide Antibiotics in Wastewater Treatment Plants and in the Glatt Valley Watershed, Switzerland. Environmental Science and Technology, 37(24), 5479-5486.

Monteiro, S. C. and Boxall, A. B. (2010). Occurrence and Fate of Human Pharmaceuticals in the Environment. In Whitacre, D. M., editor, "Reviews of Environmental Contamination and Toxicology", volume 202, pages 54-154. Springer, New York, NY.

Moretti, B., Grignani, C., Bechini, L., \& Sacco, D. (2015). Efficacia e convenienza delle catch crop. L’informatore Agrario, (36), 52-56.

National Food Institute, Technical University of Denmark (2018). Danish (Q)SAR Database. URL: http://qsar.food.dtu.dk. Last accessed: 23-03-2019.

Nelli, E. and Sodi, F. (2007). Riso - Oryza sativa L. - Atlante delle coltivazioni erbacee - Piante industriali. URL: http://www.agraria.org/coltivazionierbacee/riso.htm. Last accessed: 5-10-2018.

Patlewicz, G., Jeliazkova, N., Safford, R. J., Worth, A. P., \& Aleksiev, B. (2008). An evaluation of the implementation of the Cramer classification scheme in the Toxtree software. SAR and QSAR in Environmental Research, 19(5-6), 495-524.

Piña, B., Bayona, J.M., Christou, A., Fatta-Kassinos, D., Guillon, E., Lambropoulou, D., Michael, C., Polesel, F., Sayen, S. (2018). On the contribution of reclaimed wastewater irrigation to the potential exposure of humans to antibiotics, antibiotic resistant bacteria and antibiotic resistance genes - NEREUS COST Action ES1403 position paper. Journal of Environmental Chemical Engineering.

Pizza, F. (2014). Agricultural reuse of treated wastewater : the case of Milano-Nosedo municipal wastewater treatment plant. In D. Santoro, Trojan Technologies, \& Western University (Eds.), 
Wastewater and Biosolids Treatment and Reuse: Bridging Modeling and Experimental Studies. ECI Symposium Series.

719 Polesel, F., Plósz, B.G., Trapp, S. (2015). From consumption to harvest: Environmental fate 720 prediction of excreted ionizable trace organic chemicals. Water Research 84, 85-98.

721 Prosser, R. S., Lissemore, L., Topp, E., \& Sibley, P. K. (2014a). Bioaccumulation of triclosan and triclocarban in plants grown in soils amended with municipal dewatered biosolids. Environmental Toxicology and Chemistry, 33(5), 975-984.

724 Prosser, R. S., \& Sibley, P. K. (2015). Human health risk assessment of pharmaceuticals and 725 personal care products in plant tissue due to biosolids and manure amendments, and wastewater 726 irrigation. Environment International, 75, 223-233.

727 Prosser, R. S., Trapp, S., \& Sibley, P. K. (2014b). Modeling Uptake of Selected Pharmaceuticals 728 and Personal Care Products into Food Crops from Biosolids-Amended Soil. Environmental 729 Science \& Technology, 48(19), 11397-11404.

730 Provincia di Milano (2007). Piano di Settore Agricolo. Relazione Generale.

731 Riemenschneider, C., Al-Raggad, M., Moeder, M., Seiwert, B., Salameh, E., \& Reemtsma, T. 732 (2016). Pharmaceuticals, Their Metabolites, and Other Polar Pollutants in Field-Grown 733 Vegetables Irrigated with Treated Municipal Wastewater. Journal of Agricultural and Food $734 \quad$ Chemistry, 64(29), 5784-5792.

735 Riva, F., Zuccato, E., Davoli, E., Fattore, E., \& Castiglioni, S. (2019). Risk assessment of a mixture 736 of emerging contaminants in surface water in a highly urbanized area in Italy. Journal of $737 \quad$ Hazardous Materials, 361, 103-110.

738 Rosenbaum, R. K., Mckone, T. E., \& Jolliet, O. (2009). CKow: A dynamic model for chemical 739 transfer to meat and milk. Environmental Science and Technology, 43(21), 8191-8198.

740 Sabaliunas, D., Webb, S. F., Hauk, A., Jacob, M., and Eckhoff, W. S. (2003). Environmental fate of 741 Triclosan in the River Aire Basin, UK. Water Research, 37(13):3145-3154. 
Saltelli, A., Andres, T. H., \& Homma, T. (1993). Sensitivity analysis of model output: An investigation of new techniques. Computational Statistics \& Data Analysis, 15(2), 211-238.

744 Schwarzenbach, R. P., Gschwend, P. M., \& Imboden, D. M. (2003). Environmental Organic

Siemens, J., Huschek, G., Siebe, C., and Kaupenjohann, M. (2008). Concentrations and mobility of human pharmaceuticals in the world's largest wastewater irrigation system, Mexico CityMezquital Valley. Water Research, 42(8-9):2124-2134.

Sin, G., Gernaey, K. V., Neumann, M. B., van Loosdrecht, M. C. M., \& Gujer, W. (2011). Global sensitivity analysis in wastewater treatment plant model applications: Prioritizing sources of uncertainty. Water Research, 45(2), 639-651.

Steinwand, A. L., Harrington, R. F., \& Groeneveld, D. P. (2001). Transpiration coefficients for three Great Basin shrubs. Journal of Arid Environments, 49(3), 555-567.

Sui, Q., Huang, J., Deng, S., Chen, W., \& Yu, G. (2011). Seasonal variation in the occurrence and removal of pharmaceuticals and personal care products in different biological wastewater treatment processes. Environmental Science and Technology, 45(8), 3341-3348.

Trapp, S. (2017). Coupled soil-plant uptake model for monovalent ionics. First release June 2017 at https://homepage.env.dtu.dk/stt/2017Release_Plant_Model/index.htm

Trapp, S. (2015). Calibration of a plant uptake model with plant- and site-specific data for uptake of chlorinated organic compounds into radish. Environmental Science and Technology, 49(1), 395402.

Trapp S. (2009) Bioaccumulation of Polar and Ionizable Compounds in Plants. In: Devillers J. (eds) Ecotoxicology Modeling. Emerging Topics in Ecotoxicology (Principles, Approaches and Perspectives), vol 2. Springer, Boston, MA

Trapp S, Ma L Bomholtz, Legind CN. (2008). Coupled mother-child model for bioaccumulation of POPs in nursing infants. Environmental Pollution 156, 90-98. 
767 Trapp, S. (2004). Plant Uptake and Transport Models for Neutral and Ionic Chemicals. 768 Environmental Science and Pollution Research, 11(1), 33-39.

769 Trapp, S., \& Horobin, R. W. (2005). A predictive model for the selective accumulation of chemicals $770 \quad$ in tumor cells. European Biophysics Journal, 34(7), 959-966.

771 Trapp, S., \& Matthies, M. (1998). Chemodynamics and Environmental Modelling. An introduction. 772 New York, NY: Springer-Verlag.

773 Travis, C. C., \& Arms, A. D. (1988). Bioconcentration of Organics in Beef, Milk, and Vegetation. 774 Environmental Science and Technology, 22(3), 271-274.

775 Vezzaro, L., Benedetti, L., Gevaert, V., De Keyser, W., Verdonck, F., De Baets, B., ... Mikkelsen, 776 P. S. (2014). A model library for dynamic transport and fate of micropollutants in integrated 777 urban wastewater and stormwater systems. Environmental Modelling and Software, 53, 98-111. 778 Voinov, A., Shugart, H.H., 2013. "Integronsters", integral and integrated modeling. Environ. $779 \quad$ Model. Softw. 39, 149-158.

780 Vreugdenhil, D., \& Koot-Gronsveld, E. A. M. (1989). Measurements of pH, Sucrose and 781 Potassium-Ions in the Phloem Sap of Castor Bean (Ricinus-Communis) Plants. Physiologia $782 \quad$ Plantarum, 77, 385-388.

783 Wang, Z., MacLeod, M., Cousins, I. T., Scheringer, M., \& Hungerbühler, K. (2011). Using 784 COSMOtherm to predict physicochemical properties of poly- and perfluorinated alkyl 785 substances (PFASs). Environmental Chemistry, 8(4), 389-398.

786 Winkler, M., Lawrence, J. R., \& Neu, T. R. (2001). Selective degradation of ibuprofen and clofibric 787 acid in two model river biofilm systems. Water Research, 35(13), 3197-3205.

788 Writer, J. H., Antweiler, R. C., Ferrer, I., Ryan, J. N., \& Thurman, E. M. (2013). In-stream 789 attenuation of neuro-active pharmaceuticals and their metabolites. Environmental Science and $790 \quad$ Technology, 47(17), 9781-9790. 
791 Wu, X., Conkle, J. L., Ernst, F., \& Gan, J. (2014). Treated wastewater irrigation: Uptake of 792 pharmaceutical and personal care products by common vegetables under field conditions. 793 Environmental Science and Technology, 48(19), 11286-11293.

794 Xu, J., Wu, L., \& Chang, A. C. (2009). Degradation and adsorption of selected pharmaceuticals and 795 personal care products (PPCPs) in agricultural soils. Chemosphere, 77(10), 1299-1305. 


\title{
Risk assessment of contaminants of emerging concern in the context of wastewater reuse for irrigation: An integrated modelling approach
}

\author{
Supplementary Material
}

Number of pages: 32; $\quad$ Number of Tables: 24; $\quad$ Number of Figures: 20;

Riccardo Delli Compagni ${ }^{1}$, Marco Gabrielli ${ }^{1}$, Fabio Polesel $^{2,3}$, Andrea Turolla ${ }^{1}$, Stefan Trapp ${ }^{2}$, Luca Vezzaro $^{2}$, Manuela Antonelli ${ }^{*}$

${ }^{1}$ Politecnico di Milano, Department of Civil and Environmental Engineering (DICA), Piazza Leonardo da Vinci 32, 20133 Milano, Italy

${ }^{2}$ DTU Environment, Technical University of Denmark, Bygningstorvet, Building 115, 2800 Kongens Lyngby, Denmark

${ }^{3}$ DHI A/S, Agern Allé 5, 2970 Hørsholm, Denmark

*Corresponding author: manuela.antonelli@polimi.it 


\section{Index}

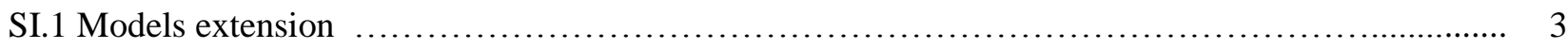

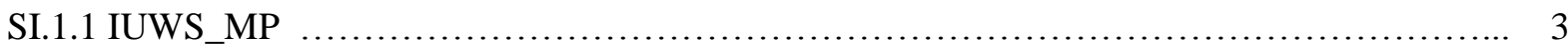

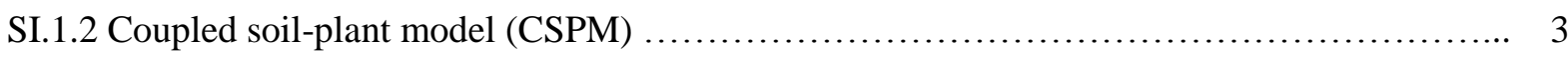

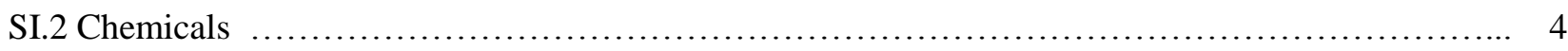

SI.2.1 CECs physicochemical properties and degradation rates $\ldots \ldots \ldots \ldots \ldots \ldots \ldots \ldots \ldots \ldots \ldots . \quad 4$

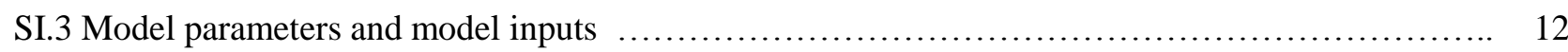

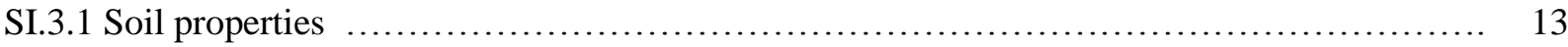

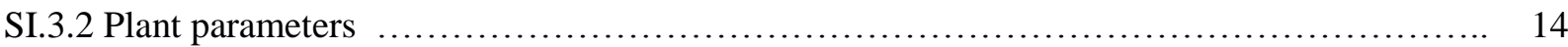

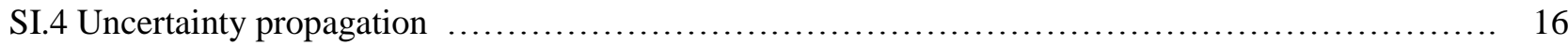

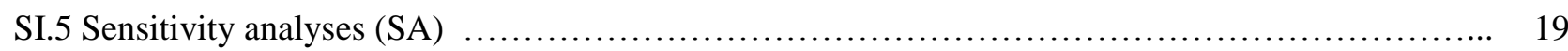

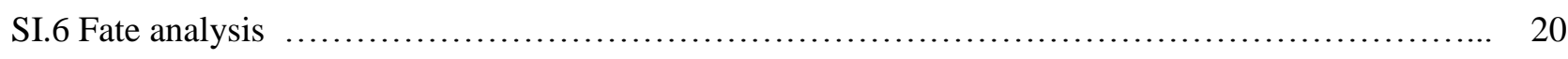

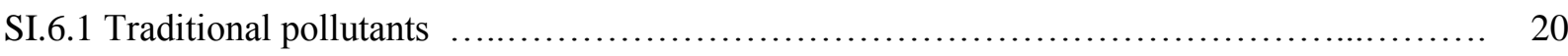

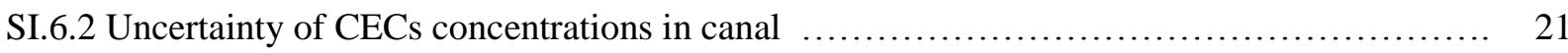

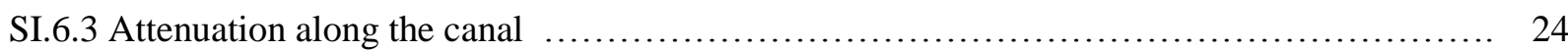

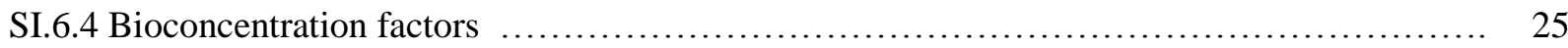

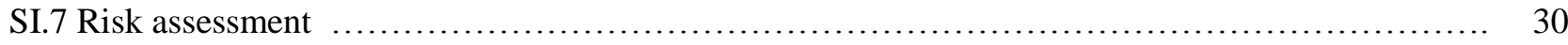

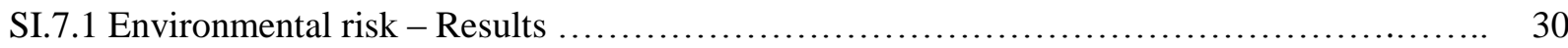

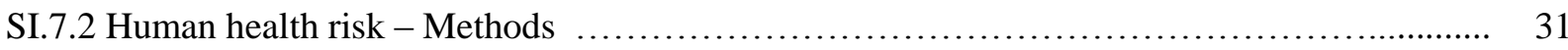

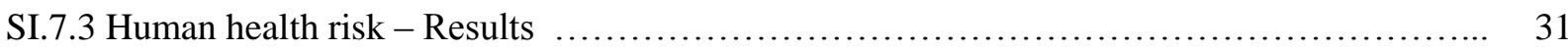

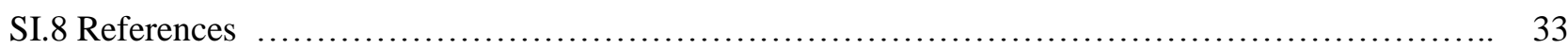




\section{SI.1 Models extension}

\section{SI.1.1 IUWS_MP}

CECs are often ionized at environmentally relevant pH (Franco et al., 2010). While sorption of neutral chemicals occurs due to Van der Waals forces, in the presence of ions, the process is dominated by the stronger electrical forces. Hence, neutral molecules, anions and cations present different sorption behaviors which are furthermore affected by the degree of ionic speciation (Franco and Trapp, 2008). The Koc formula was updated accordingly to Franco et al. (2013) as shown in Eq. S1.

$$
\begin{aligned}
& K o c_{\text {acid }}=\Phi_{n} 10^{0.54 \log K o w+1.11}+\Phi_{i} 10^{0.11 \log K o w+1.54} \\
& \text { Koc }_{\text {base }}=10^{\text {logDow }+2.78}
\end{aligned}
$$

The sorption of the charged and neutral fractions of monovalent chemicals is described as a function of Kow or Dow, $\mathrm{pK}_{\mathrm{a}}$ and, in case of acids, also the solution $\mathrm{pH} . \Phi_{n}$ and $\Phi_{i}$ are respectively the neutral and anionic CECs fractions calculated at $\mathrm{pH}_{\mathrm{opt}}=\mathrm{pH}-0.6$. The range of applicability is $\mathrm{pK}_{\mathrm{a}}<10$ for monovalent acids and $\mathrm{pK}_{\mathrm{a}}>4$ for monovalent bases (Franco et al., 2013).

Environmental properties are intrinsically dynamic (Kunkel and Radke, 2011; Matamoros and Rodriguez, 2017) and the use of constant values would not properly describe realistic conditions. Hence, the use of external measurement inputs was allowed for the following properties:

- Sunlight intensity

- Water $\mathrm{pH}$

- Air temperature

- Water temperature

- Wind speed

Irrigation is, also, seasonal dependent (Portmann et al., 2008). For this reason, the flow splitters, used to simulate the water withdrawal, were, thus, enhanced to describe a dynamic pattern throughout the year.

\section{SI.1.2 Coupled soil-plant model (CSPM)}

Figure $\mathrm{S} 1$ shows the modelled flows mainly responsible for CECs traslocation inside the plants.

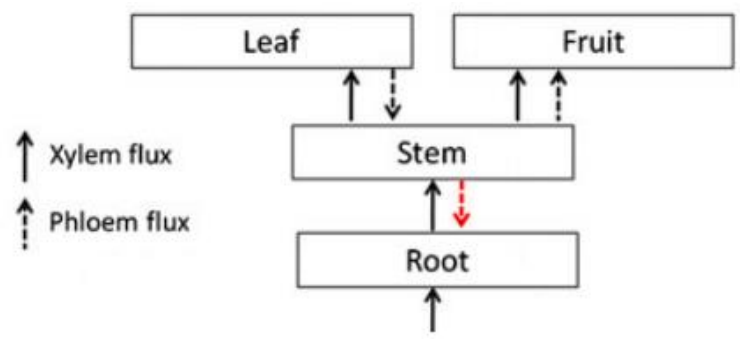

Figure S1. Modelled CECs flows inside the plants. In red the new phloem flux added.

As multiple crops are commonly grown on the same field within the same year (Borrelli et al., 2014), the model was extended to describe the succession of two different crops within the same year. Furthermore, an extra input was added to the model to account for the water and CECs mass added to the first soil layer through irrigation and the time-step used in the solution scheme was refined to prevent numerical issues. 
Soil $\mathrm{pH}$ is not constant with depth, especially in agricultural field in which the surface layers are extensively plowed and fertilized (Zhang et al., 2017b). Therefore, a pH value was given to each of the five soil layers present in the model. Moreover, soil temperatures vary throughout the year due to the fluctuations of air temperature and solar radiation. As depth increases, temperatures are more uniform throughout the year, compared to the overlying layers (Xing and Spitler, 2017). Hence, a daily temperature was added for each of the layers 2-5, while the surface layer temperature was assumed equal to the air above.

\section{SI.2 Chemicals}

Table S1. PNECs of selected CECs.

\begin{tabular}{|c|c|c|c|}
\hline & & PNEC value (ng/L) & Reference \\
\hline clarithromycin & CLA & 200 & Zhao et al. (2017b) \\
\hline sulfamethoxazole & SMX & 890 & Huang et al. (2018) \\
\hline diclofenac & $\mathrm{DCF}$ & 9800 & Zhao et al. (2017b) \\
\hline ibuprofen & IBU & 18 & Huang et al. (2018) \\
\hline paracetamol & PAR & 367 & Riva et al. (2019) \\
\hline carbamazepine & $\mathrm{CBZ}$ & 9000 & Zhao et al. (2017b) \\
\hline furosemide & FUR & 45100 & Riva et al. (2019) \\
\hline $17-\beta$ estradiol & E2 & 2 & Caldwell et al. (2012) \\
\hline estrone & E1 & 6 & Caldwell et al. (2012) \\
\hline 17- $\alpha$ ethinylestradiol & EE2 & 0.1 & Caldwell et al. (2012) \\
\hline perfluorooctanoic acid & PFOA & 1.07E06 & Gredelj et al. (2018) \\
\hline perfluorooctane sulfonate & PFOS & $1.6 \mathrm{E} 04$ & Gredelj et al. (2018) \\
\hline triclosan & TCS & 2.6 & Gredelj et al. (2018) \\
\hline
\end{tabular}

\section{SI.2.1 CECs physicochemical properties and degradation rates}

Table S2 presents the physicochemical values used during the simulations. QSAR estimates of CLogP and ECOSAR of PFOS and PFOA were discarded as not reliable (Arp et al., 2006).

Table S2. Physicochemical properties of the selected CECs. All properties from Advanced Chemistry Development Inc. (2015), unless noted. (b) indicates a basic $\mathrm{pK}_{\mathrm{a}}$

\begin{tabular}{|c|c|c|c|c|c|c|c|}
\hline CEC & $\begin{array}{l}\text { Mol mass } \\
(\mathrm{g} / \mathrm{mol})\end{array}$ & $\mathrm{pK}_{\mathrm{a}}$ & $\begin{array}{l}\text { Vapor P } \\
(\mathrm{mmHg})\end{array}$ & $\begin{array}{l}\log (\mathrm{Sw}) \\
(\mathrm{M})\end{array}$ & $\log ($ Kow $)$ & $\log (\mathrm{Koc})$ & $\log \left(\mathrm{K}_{\mathrm{HSA}}\right)$ \\
\hline CLA & 747.95 & 8.5 (b) & 0 & -3.29 & 3.2 & & 2.77 \\
\hline \multirow[t]{6}{*}{ SMX } & 253.28 & 5.7 & $1.9 \mathrm{E}-09$ & -2.62 & 0.89 & $2.34^{28}$ & 2.86 \\
\hline & & & & & & $1.79^{28}$ & \\
\hline & & & & & & $1.3^{28}$ & \\
\hline & & & & & & $1.4^{28}$ & \\
\hline & & & & & & $2.06^{28}$ & \\
\hline & & & & & & $3.47^{28}$ & \\
\hline
\end{tabular}


Table S2. Cont.

\begin{tabular}{|c|c|c|c|c|c|c|c|}
\hline DCF & 296.15 & 4.4 & $1.59 \mathrm{E}-07$ & -5.1 & 4.4 & & 4.91 \\
\hline IBU & 206.28 & 4.3 & $1.39 \mathrm{E}-04$ & -3.99 & 3.4 & & 4.74 \\
\hline PAR & 151.06 & 10.2 & $1.43 \mathrm{E}-06$ & -0.99 & 0.46 & $1.55^{1}$ & 2.43 \\
\hline CBZ & 236.27 & - & $5.78 \mathrm{E}-07$ & -3.33 & 2.3 & & 3.91 \\
\hline FUR & 330.74 & 3.5 & 0 & -3.66 & 2.03 & & 5.27 \\
\hline E2 & 272.38 & 10 & $9.8 \mathrm{E}-09$ & -4.64 & 3.36 & & 4.41 \\
\hline E1 & 270.37 & 9.9 & $1.54 \mathrm{E}-08$ & -3.95 & 3.13 & & 1.06 \\
\hline EE2 & 296.40 & 10 & 3.7E-09 & -4.7 & 3.54 & & 3.55 \\
\hline \multirow[t]{12}{*}{ PFOA } & 414.07 & $2.4,0.5$ & $3.14 \mathrm{E}-02^{13}$ & -4.54 & 4.6 , & $2.06^{17}$ & 5.02 \\
\hline & & $3.8^{5}$ & $3.11 \mathrm{E}-03^{13}$ & $-1.98^{2}$ & 7.75 & $1.9^{17}$ & $4.0^{20}$ \\
\hline & & $0.5^{6}$ & $3.14 \mathrm{E}-02^{13}$ & $-2.01^{11}$ & $4.3^{14}$ & $2.17^{17}$ & $3.4^{20}$ \\
\hline & & $1.31^{7}$ & $2.4 \mathrm{E}-03^{14}$ & $-2.09^{2}$ & $5.3^{8}$ & $1.1^{15}$ & $3.42^{21}$ \\
\hline & & $1.01^{4}$ & $2.25 \mathrm{E}-04^{14}$ & $-1.64^{2}$ & $4.59^{14}$ & $3.2^{15}$ & $4.34^{22}$, \\
\hline & & $<1^{15}$ & $9.02 \mathrm{E}-02^{19}$ & $-2.73^{8}$ & $1.92^{13}$ & $1.47^{27}$ & $3.57^{23}$ \\
\hline & & $2.5^{12}$ & $1.5 \mathrm{E}-01^{19}$ & & $6.26^{15}$ & & $4.38^{24}$, \\
\hline & & $2.8^{3}$ & & & & & $5.16^{24}$ \\
\hline & & $0.9^{8}, 0^{9}$ & & & & & $4.5^{24}$ \\
\hline & & $0^{13}$ & & & & & \\
\hline & & $-0.21^{10}$ & & & & & \\
\hline & & $2.14^{11}$ & & & & & \\
\hline \multirow[t]{8}{*}{ PFOS } & 500.13 & -5.7 & $2.6 \mathrm{E}-02^{14}$ & -5.05 & 2.59 & $1.6^{15}$ & 5.02 \\
\hline & & -3.7 & $2.54 \mathrm{E}-01^{14}$ & $-3.84^{8},-$ & 7.03 & $4.8^{15}$ & $7.1^{20}$ \\
\hline & & $-3.41^{8}$ & $2.34 \mathrm{E}-03^{19}$ & $3.79^{15}$ & $5.25^{14}$ & $2.57^{17}$ & $3.4^{20}$ \\
\hline & & $0.14^{10}$ & $1.13 \mathrm{E}-01^{15}$ & & $5.26^{14}$ & $2.57^{17}$ & $3.51^{25}$ \\
\hline & & $-3.3^{12}$ & & & $2.45^{16}$ & $3.1^{17}$ & $3.6^{25}$ \\
\hline & & & & & $4.67^{15}$ & $1.82^{18}$ & $3.66^{23}$, \\
\hline & & & & & & & $5.12^{23}$ \\
\hline & & & & & & & $3.7^{26}$ \\
\hline TCS & 289.54 & 8.8 & 4E-06 & -4.46 & 4.76 & & 4.81 \\
\hline
\end{tabular}

References: 1: ECHA (2006), 2: Jensen et al. (2008), 3: Brace (1962), 4: Igarashi and Yotsuyanagi (1992), 5: Burns et al. (2009), 6: Vierke et al. (2013), 7: López-Fontán et al. (2005), 8: Wang et al. (2011), 9: Goss (2008), 10: Ahrens et al. (2012), 11: Nielsen (2012), 12: EFSA Scientific Commitee (2008), 13: Ding and Peijnenburg (2013), 14: Arp et al. (2006), 15: Rayne and Forest (2009b), 16: Jing et al. (2009), 17: Higgins and Luthy (2006), 18: Stevens and Coryell (2007), 19: Bhhatarai and Gramatica (2011), 20: Beesoon and Martin (2015), 21: Han et al. (2003), 22: Hebert and MacManus-Spencer (2010), 23: Chen and Guo (2009), 24: Bischel et al. (2010), 25: Wu et al. (2009), 26: Li et al. (2009), 27: Rahman et al. (2014), 28: Barron et al. (2009). 
Table S3. CLA degradation rates.

\begin{tabular}{|c|c|c|c|c|c|c|c|}
\hline \multicolumn{2}{|c|}{$\begin{array}{c}\text { Near-surface } \\
\text { photodegradation }\end{array}$} & \multicolumn{6}{|c|}{ Biodegradation } \\
\hline \multirow[b]{2}{*}{$\begin{array}{l}K_{\text {pho,nearsurf }} \\
\left(d^{-1}\right)\end{array}$} & \multirow[b]{2}{*}{ Reference } & \multicolumn{2}{|c|}{ Sediments } & \multicolumn{2}{|c|}{ Water } & \multicolumn{2}{|c|}{ Soil } \\
\hline & & $\begin{array}{l}\mathrm{K}_{\text {bio,sed }} \\
\left(\mathrm{d}^{-1}\right)\end{array}$ & Reference & $\begin{array}{l}\begin{array}{l}K_{\text {bio,wat }} \\
\left(\mathrm{d}^{-1}\right)\end{array}\end{array}$ & Reference & $\begin{array}{l}\mathrm{K}_{\text {bio,soil }} \\
\left(\mathrm{d}^{-1}\right)\end{array}$ & Reference \\
\hline 0.23 & $\begin{array}{l}\text { Calza et al. } \\
(2013)\end{array}$ & $\begin{array}{l}2.31 \mathrm{E}-03- \\
2.31 \mathrm{E}-04\end{array}$ & $\begin{array}{l}\text { JRC } \\
(2003)\end{array}$ & Negligible & $\begin{array}{l}\text { Alexy et al. } \\
(2004)\end{array}$ & $\begin{array}{l}<6.93 \mathrm{E}-4- \\
7.80 \mathrm{E}-3\end{array}$ & $\begin{array}{l}\text { Kodešová et al. } \\
(2016)\end{array}$ \\
\hline \multirow[t]{2}{*}{0.13} & \multirow{2}{*}{\multicolumn{3}{|c|}{ Gozlan and Koren (2016) }} & $<6.6 \mathrm{E}-03$ & \multicolumn{3}{|c|}{ Calza et al. (2013) } \\
\hline & & & & $\begin{array}{l}<9.9 \mathrm{E}-02 \\
3.56 \mathrm{E}-3- \\
1.39 \mathrm{E}-3\end{array}$ & \multicolumn{3}{|c|}{ Hanamoto et al. (2013) } \\
\hline
\end{tabular}

Table S4. SMX degradation rates. (an) for anaerobic or anoxic conditions.

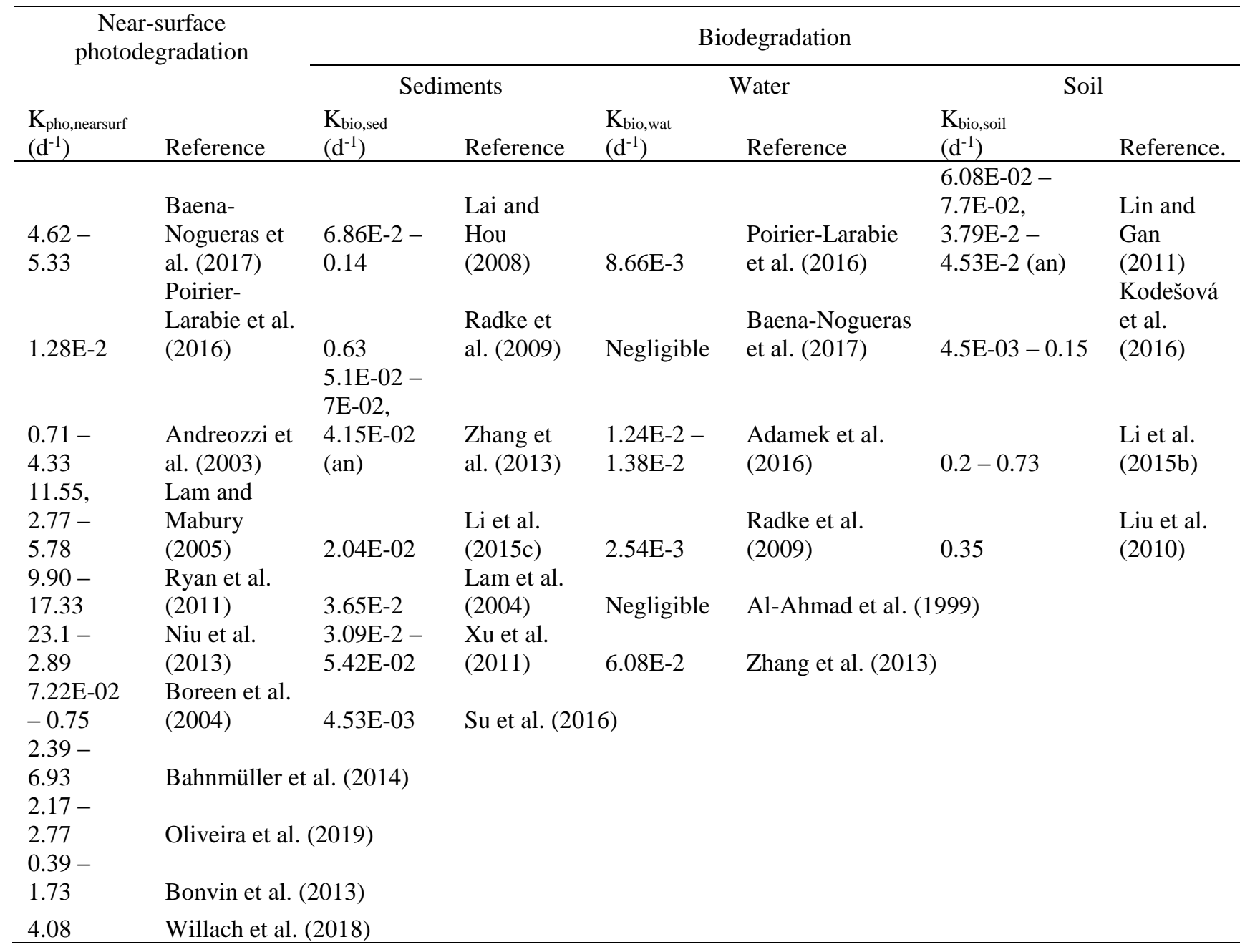


Table S5. DCF degradation rates. (an) for anaerobic or anoxic conditions.

\begin{tabular}{|c|c|c|c|c|c|c|c|}
\hline \multicolumn{2}{|c|}{$\begin{array}{c}\text { Near-surface } \\
\text { photodegradation }\end{array}$} & \multicolumn{6}{|c|}{ Biodegradation } \\
\hline \multirow[b]{2}{*}{$\begin{array}{l}\mathrm{K}_{\text {pho,nearsurf }} \\
\left(\mathrm{d}^{-1}\right)\end{array}$} & \multirow[b]{2}{*}{ Reference } & \multicolumn{2}{|c|}{ Sediments } & \multicolumn{2}{|c|}{ Water } & \multicolumn{2}{|r|}{ Soil } \\
\hline & & $\begin{array}{l}\mathrm{K}_{\text {bio,sed }} \\
\left(\mathrm{d}^{-1}\right)\end{array}$ & Reference & $\begin{array}{l}\mathrm{K}_{\text {bio,wat }} \\
\left(\mathrm{d}^{-1}\right)\end{array}$ & Reference & $\begin{array}{l}\mathrm{K}_{\text {bio,soil }} \\
\left(\mathrm{d}^{-1}\right)\end{array}$ & Reference \\
\hline 17.33 & $\begin{array}{l}\text { Buser et al. } \\
\text { (1998) }\end{array}$ & $\begin{array}{l}3.73 \mathrm{E}-03- \\
0.13 \\
3.45 \mathrm{E}-02, \\
1.54 \mathrm{E}-2-\end{array}$ & $\begin{array}{l}\text { Kunkel and } \\
\text { Radke (2008) }\end{array}$ & Negligible & $\begin{array}{l}\text { Baena- } \\
\text { Nogueras et al. } \\
(2017)\end{array}$ & $\begin{array}{l}2.34 \mathrm{E}-2 \\
-0.14\end{array}$ & $\begin{array}{l}\text { Lin and Gan } \\
\text { (2011) }\end{array}$ \\
\hline 86.64 & $\begin{array}{l}\text { Poiger et al. } \\
(2001) \\
\text { Poirier- }\end{array}$ & $\begin{array}{l}1.84 \mathrm{E}-02 \\
\text { (an) }\end{array}$ & $\begin{array}{l}\text { Koumaki et al. } \\
\text { (2017) }\end{array}$ & $4.08 \mathrm{E}-3$ & $\begin{array}{l}\text { Buser et al. } \\
\text { (1998) }\end{array}$ & $\begin{array}{l}3.39 \mathrm{E}-2 \\
-0.23\end{array}$ & $\begin{array}{l}\text { Xu et al. } \\
(2009)\end{array}$ \\
\hline 1.73 & $\begin{array}{l}\text { Larabie et al. } \\
(2016) \\
\text { Baena- }\end{array}$ & $\begin{array}{l}2.39 \mathrm{E}-02- \\
7.7 \mathrm{E}-02\end{array}$ & $\begin{array}{l}\text { Radke and } \\
\text { Maier (2014) }\end{array}$ & $9.9 \mathrm{E}-03$ & $\begin{array}{l}\text { Poirier-Larabie } \\
\text { et al. (2016) }\end{array}$ & 1.73 & $\begin{array}{l}\text { Grossberger } \\
\text { et al. (2014) }\end{array}$ \\
\hline $\begin{array}{l}99.02- \\
115.52\end{array}$ & $\begin{array}{l}\text { Nogueras et } \\
\text { al. }(2017)\end{array}$ & $\begin{array}{l}8 \mathrm{E}-3- \\
2.6 \mathrm{E}-2\end{array}$ & Gröning et al. (2 & $007)$ & & & \\
\hline $\begin{array}{l}34.66 \\
0.35- \\
3.47 \\
2.31- \\
23.1\end{array}$ & $\begin{array}{l}\text { Packer et al. } \\
\text { Andreozzi et } \\
\text { Koumaki et al }\end{array}$ & $\begin{array}{l}003) \\
(2003) \\
(2015)\end{array}$ & & & & & \\
\hline $\begin{array}{l}231.05 \\
266.59- \\
277.26\end{array}$ & Zhang et al. & 17a) & & & & & \\
\hline 6.93 & \multicolumn{7}{|c|}{ Vochezer (2010) } \\
\hline 11.55 & \multicolumn{7}{|c|}{ Radke et al. (2010) } \\
\hline
\end{tabular}

Table S6. IBU degradation rates. (an) for anaerobic or anoxic conditions.

\begin{tabular}{|c|c|c|c|c|c|c|c|}
\hline \multicolumn{2}{|c|}{$\begin{array}{c}\text { Near-surface } \\
\text { photodegradation }\end{array}$} & \multicolumn{6}{|c|}{ Biodegradation } \\
\hline \multirow[b]{2}{*}{$\begin{array}{l}\mathrm{K}_{\text {pho,nearsurf }} \\
\left(\mathrm{d}^{-1}\right)\end{array}$} & \multirow[b]{2}{*}{ Reference } & \multicolumn{2}{|c|}{ Sediments } & \multicolumn{2}{|c|}{ Water } & \multicolumn{2}{|c|}{ Soil } \\
\hline & & $\begin{array}{l}K_{\text {bio,sed }} \\
\left(\mathrm{d}^{-1}\right)\end{array}$ & Reference & $\begin{array}{l}K_{\text {bio,wat }} \\
\left(d^{-1}\right)\end{array}$ & Reference & $\begin{array}{l}\mathrm{K}_{\text {bio,soil }} \\
\left(\mathrm{d}^{-1}\right)\end{array}$ & Reference \\
\hline $1.68 \mathrm{E}-03$ & & $3.65 \mathrm{E}-02-9.9 \mathrm{E}-$ & & & Baena- & $4.56 \mathrm{E}-02$ & \\
\hline $\begin{array}{l}-2.77 \mathrm{E}- \\
02\end{array}$ & $\begin{array}{l}\text { Yamamoto } \\
\text { et al. (2009) }\end{array}$ & $\begin{array}{l}02,1.27 \mathrm{E}-03- \\
3.35 \mathrm{E}-03 \text { (an) }\end{array}$ & $\begin{array}{l}\text { Conkle et al. } \\
\text { (2012) }\end{array}$ & $1.2 \mathrm{E}-02$ & $\begin{array}{l}\text { Nogueras et } \\
\text { al. (2017) }\end{array}$ & $\begin{array}{l}-6.66 \mathrm{E}- \\
02\end{array}$ & $\begin{array}{l}\text { Lin and } \\
\text { Gan }(2011)\end{array}$ \\
\hline 7.97E-02 & $\begin{array}{l}\text { Fono et al. } \\
(2006) \\
\text { Baena- }\end{array}$ & $\begin{array}{l}0.43,9.52 \mathrm{E}-03- \\
2.11 \mathrm{E}-02 \text { (an) }\end{array}$ & $\begin{array}{l}\text { Koumaki et } \\
\text { al. (2017) } \\
\text { Kunkel and }\end{array}$ & $3.47 \mathrm{E}-02$ & $\begin{array}{l}\text { Buser et al. } \\
\text { (1999) }\end{array}$ & $\begin{array}{l}0.11- \\
0.76 \\
2.28 \mathrm{E}-02\end{array}$ & $\begin{array}{l}\text { Xu et al. } \\
(2009)\end{array}$ \\
\hline $5.13 \mathrm{E}-02$ & $\begin{array}{l}\text { Nogueras et } \\
\text { al. (2017) }\end{array}$ & $0.14-0.28$ & $\begin{array}{l}\text { Radke } \\
(2008)\end{array}$ & $\begin{array}{l}3.47 \mathrm{E}-02- \\
3.69 \mathrm{E}-02\end{array}$ & $\begin{array}{l}\text { Yamamoto et } \\
\text { al. }(2009)\end{array}$ & $\begin{array}{l}-4.06 \mathrm{E}- \\
04\end{array}$ & $\begin{array}{l}\text { Carr et al. } \\
\text { (2011) } \\
\text { Grossberge }\end{array}$ \\
\hline $\begin{array}{l}0.58- \\
0.72\end{array}$ & $\begin{array}{l}\text { Packer et al. } \\
(2003)\end{array}$ & $\begin{array}{l}8.56 \mathrm{E}-02-2.26 \\
1.47 \mathrm{e}-02\end{array}$ & Radke and $\mathrm{M}$ & ier (2014) & & 0.86 & $\begin{array}{l}\text { r et al. } \\
(2014)\end{array}$ \\
\hline & $\begin{array}{l}\text { Peuravuori } \\
\text { and Pihlaja }\end{array}$ & & & & & & \\
\hline 6.30 & $(2009)$ & $>0.12$ & Löffler et al. & 2005) & & & \\
\hline $1.81 \mathrm{E}-02$ & $\begin{array}{l}\text { Koumaki et } \\
\text { al. (2015) }\end{array}$ & $0.36-0.39$ & Li et al. (2015 & & & & \\
\hline 1.12 & Lin and Rein & $\operatorname{ard}(2005)$ & & & & & \\
\hline 6.93 & Jakimska et &.$(2014)$ & & & & & \\
\hline
\end{tabular}


Table S7. PAR degradation rates.

\begin{tabular}{|c|c|c|c|c|c|c|c|}
\hline \multicolumn{2}{|c|}{$\begin{array}{c}\text { Near-surface } \\
\text { photodegradation }\end{array}$} & \multicolumn{6}{|c|}{ Biodegradation } \\
\hline \multirow[b]{2}{*}{$\begin{array}{l}\mathrm{K}_{\text {pho,nearsurf }} \\
\left(\mathrm{d}^{-1}\right)\end{array}$} & \multirow[b]{2}{*}{ Reference } & \multicolumn{2}{|c|}{ Sediments } & \multicolumn{2}{|r|}{ Water } & \multicolumn{2}{|c|}{ Soil } \\
\hline & & $\begin{array}{l}K_{\text {bio,sed }} \\
\left(d^{-1}\right)\end{array}$ & Reference & $\begin{array}{l}K_{\text {bio,wat }} \\
\left(d^{-1}\right)\end{array}$ & Reference & $\begin{array}{l}\mathrm{K}_{\text {bio,soil }} \\
\left(\mathrm{d}^{-1}\right)\end{array}$ & Reference \\
\hline $\begin{array}{ll}0.58 & - \\
17.32 & \end{array}$ & $\begin{array}{l}\text { Baena-Nogueras } \\
\text { et al. (2017) }\end{array}$ & 0.77 & $\begin{array}{l}\text { Lam et al. } \\
(2004)\end{array}$ & $\begin{array}{l}1.2 \mathrm{E}-02- \\
0.33\end{array}$ & $\begin{array}{l}\text { Yamamoto et al. } \\
(2009)\end{array}$ & $>0.69$ & $\begin{array}{l}\text { Li et al. } \\
\text { (2014) }\end{array}$ \\
\hline 0.33 & $\begin{array}{l}\text { Carlos et al. } \\
(2012)\end{array}$ & 0.31 & $\begin{array}{l}\text { Lin et al. } \\
(2010)\end{array}$ & $2.47 \mathrm{E}-02$ & $\begin{array}{l}\text { Baena-Nogueras et } \\
\text { al. (2017) }\end{array}$ & $\begin{array}{l}3.65- \\
3.85\end{array}$ & $\begin{array}{l}\text { Li et al. } \\
(2015 b)\end{array}$ \\
\hline $0.3-0.46$ & $\begin{array}{l}\text { Yamamoto et al. } \\
(2009)\end{array}$ & 0.22 & Löffler et al. & (2005) & & & \\
\hline Negligible & Kawabata et al. (2 & 013) & & & & & \\
\hline $\begin{array}{l}2.69 \mathrm{E}-02 \\
4.95 \mathrm{E}-02\end{array}$ & Peuravuori (2012 & & & & & & \\
\hline-0.69 & De Laurentiis et a & (2014) & & & & & \\
\hline $\begin{array}{ll}0.95 & - \\
247 & \end{array}$ & 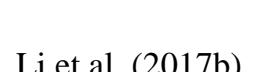 & & & & & & \\
\hline
\end{tabular}

Table S8. CBZ degradation rates. (an) for anaerobic or anoxic conditions.

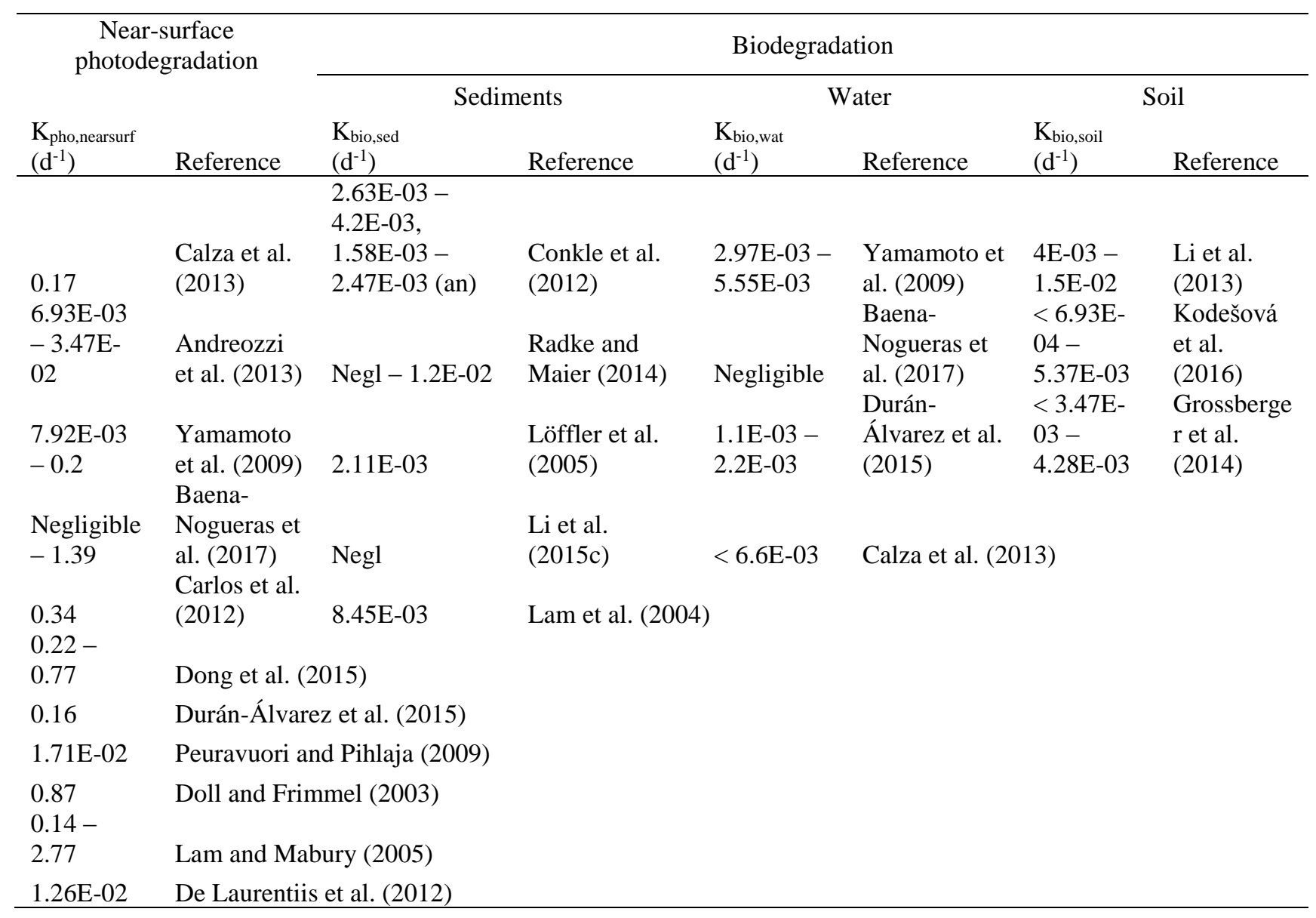


Table S9. FUR degradation rates.

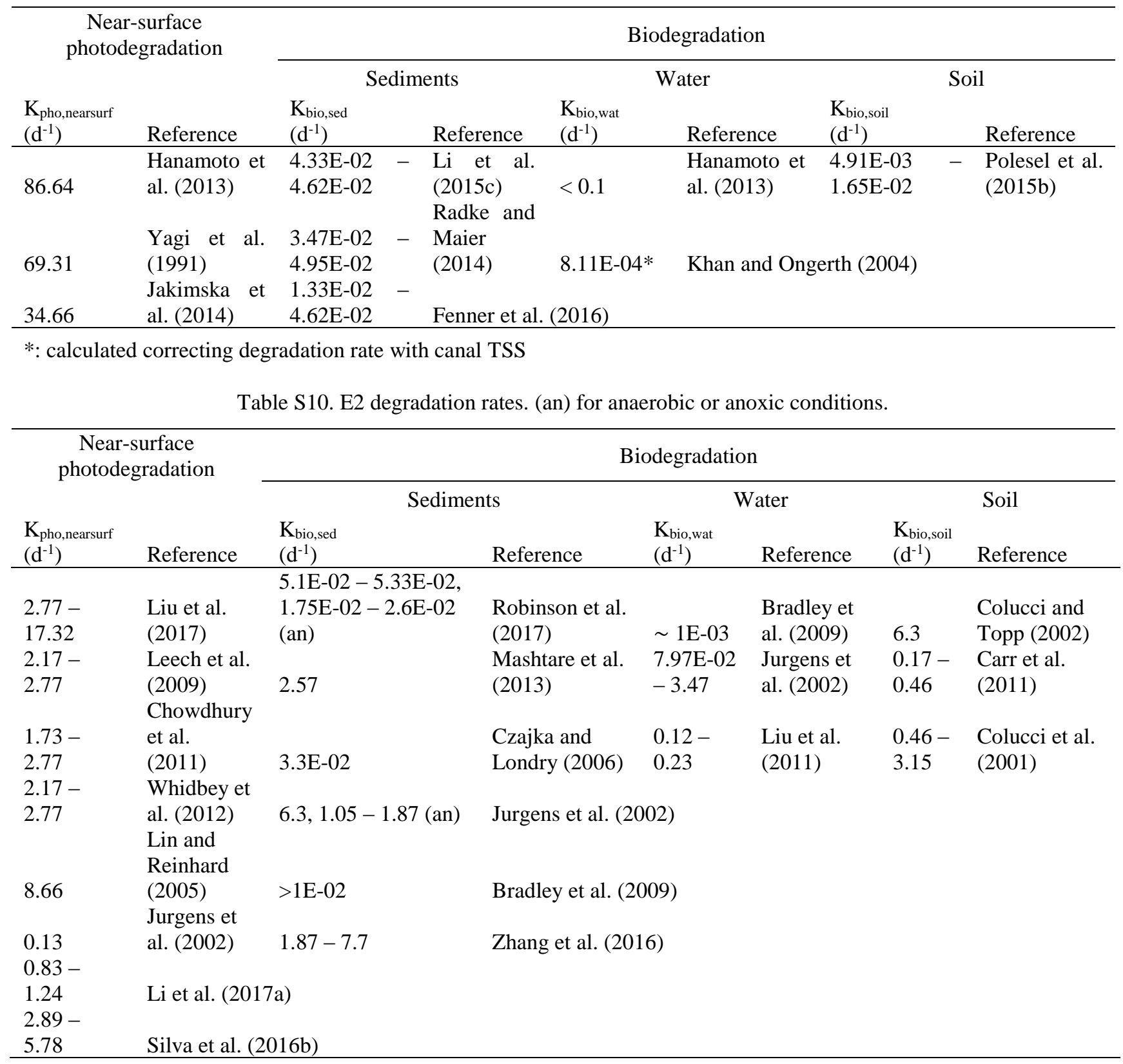


Table S11. EE2 degradation rates.

\begin{tabular}{|c|c|c|c|c|c|c|c|}
\hline \multicolumn{2}{|c|}{$\begin{array}{c}\text { Near-surface } \\
\text { photodegradation }\end{array}$} & \multicolumn{6}{|c|}{ Biodegradation } \\
\hline \multirow[b]{2}{*}{$\begin{array}{l}\mathrm{K}_{\text {pho,nearsurf }} \\
\left(\mathrm{d}^{-1}\right)\end{array}$} & \multirow[b]{2}{*}{ Reference } & \multicolumn{2}{|c|}{ Sediments } & \multicolumn{2}{|c|}{ Water } & \multicolumn{2}{|c|}{ Soil } \\
\hline & & $\begin{array}{l}\begin{array}{l}K_{\text {bio,sed }} \\
\left(\mathrm{d}^{-1}\right)\end{array} \\
\end{array}$ & Reference & $\begin{array}{l}\begin{array}{l}K_{\text {bio,wat }} \\
\left(\mathrm{d}^{-1}\right)\end{array} \\
\end{array}$ & $\begin{array}{l}\text { Referenc } \\
\mathrm{e}\end{array}$ & $\begin{array}{l}\begin{array}{l}K_{\text {bio,soil }} \\
\left(\mathrm{d}^{-1}\right)\end{array} \\
\end{array}$ & Reference \\
\hline 0.16 & $\begin{array}{l}\text { Matamoros et } \\
\text { al. (2009) }\end{array}$ & $6.42 \mathrm{E}-03$ & $\begin{array}{l}\text { Wu et al. } \\
(2015 a)\end{array}$ & Negligible & $\begin{array}{l}\text { Wu et al. } \\
\text { (2015a) } \\
\text { Jurgens }\end{array}$ & 0.83 & $\begin{array}{l}\text { Colucci and } \\
\text { Topp (2002) }\end{array}$ \\
\hline 3.85 & $\begin{array}{l}\text { Ren et al. } \\
(2016)\end{array}$ & 0.16 & $\begin{array}{l}\text { Mashtare et } \\
\text { al. (2013) } \\
\text { Czajka and }\end{array}$ & $4.08 \mathrm{E}-02$ & $\begin{array}{l}\text { et al. } \\
(2002)\end{array}$ & $\begin{array}{l}3.34 \mathrm{E}-03- \\
3.07 \mathrm{E}-02\end{array}$ & $\begin{array}{l}\text { Carr et al. } \\
\text { (2011) }\end{array}$ \\
\hline 0.72 & $\begin{array}{l}\text { Zuo et al. } \\
(2013)\end{array}$ & Negligible & $\begin{array}{l}\text { Londry } \\
(2006)\end{array}$ & $6.42 \mathrm{E}-03$ & $\begin{array}{l}\text { Zuo et al. } \\
(2013)\end{array}$ & $\begin{array}{l}2.15 \mathrm{E}-02- \\
0.37\end{array}$ & $\begin{array}{l}\text { Colucci and } \\
\text { Topp (2001) }\end{array}$ \\
\hline 3.46 & \multicolumn{3}{|c|}{ Whidbey et al. (2012) } & $<4.95 \mathrm{E}-02$ & \multicolumn{2}{|c|}{ Matsuoka et al. (2005) } & \\
\hline 6.93 & \multicolumn{3}{|c|}{ Lin and Reinhard (2005) } & Negligible & \multicolumn{2}{|c|}{ Liu et al. (2011) } & \\
\hline 0.13 & \multicolumn{3}{|c|}{ Jurgens et al. (2002) } & & & & \\
\hline $\begin{array}{l}0.73-3.46 \\
2.4 \mathrm{E}-02- \\
0.5\end{array}$ & \multicolumn{3}{|c|}{ Ren et al. (2017a) } & & & & \\
\hline $0.89-7.7$ & \multicolumn{3}{|c|}{ Silva et al. (2016b) } & & & & \\
\hline $\begin{array}{l}0.77 \\
0.63- \\
0.69\end{array}$ & \multicolumn{3}{|c|}{ Grzybowski and Szydlowski (2014) } & & & & \\
\hline 1.39 & \multicolumn{3}{|c|}{ Wu et al. (2015a) } & & & & \\
\hline
\end{tabular}

Table S12. E1 degradation rates. (an) for anaerobic or anoxic conditions.

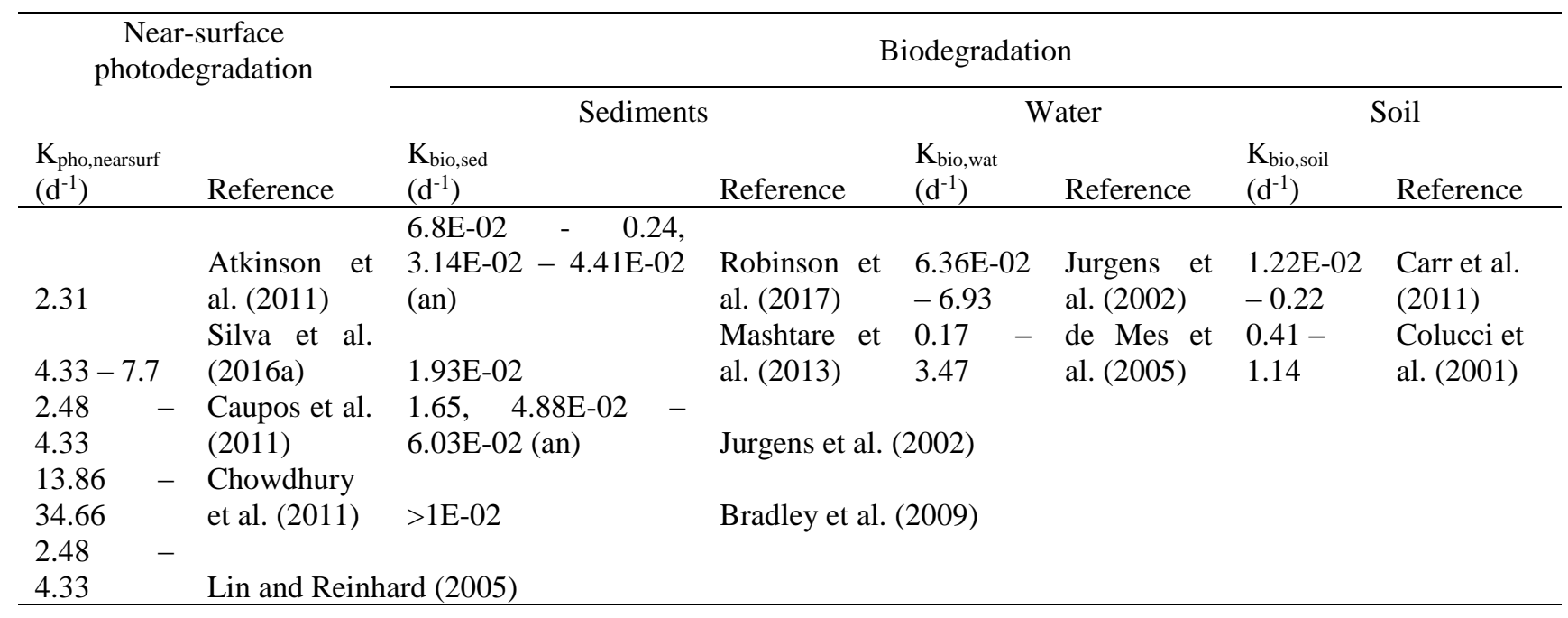

*: calculated correcting degradation rate with canal TSS

Table S13. PFOA degradation rates.

\begin{tabular}{|c|c|c|c|c|c|c|c|}
\hline \multicolumn{2}{|c|}{$\begin{array}{c}\text { Near-surface } \\
\text { photodegradation }\end{array}$} & \multicolumn{6}{|c|}{ Biodegradation } \\
\hline \multirow[b]{2}{*}{$\begin{array}{l}K_{\text {pho,nearsurf }} \\
\left(d^{-1}\right)\end{array}$} & \multirow[b]{2}{*}{ Reference } & \multicolumn{2}{|c|}{ Sediments } & \multicolumn{2}{|c|}{ Water } & \multicolumn{2}{|c|}{ Soil } \\
\hline & & $\begin{array}{l}\mathrm{K}_{\text {bio,sed }} \\
\left(\mathrm{d}^{-1}\right)\end{array}$ & Reference. & $\begin{array}{l}\mathrm{K}_{\text {bio,wat }} \\
\left(\mathrm{d}^{-1}\right)\end{array}$ & Reference & $\begin{array}{l}\mathrm{K}_{\text {bio,soil }} \\
\left(\mathrm{d}^{-1}\right)\end{array}$ & Reference \\
\hline 4.22E-04 & $\begin{array}{l}\text { Vaalgaama et } \\
\text { al. (2011) }\end{array}$ & Negligible & $\begin{array}{l}\text { Liou et al. } \\
(2010)\end{array}$ & Negligible & $\begin{array}{l}\text { Liou et al. } \\
(2010)\end{array}$ & Negligible & $\begin{array}{l}\text { Liou et al. } \\
(2010)\end{array}$ \\
\hline$<1.98 \mathrm{E}-03$ & Giesy et al. (20 & & & & & & \\
\hline
\end{tabular}


Table S14. PFOS degradation rates.

\begin{tabular}{|c|c|c|c|c|c|c|c|c|c|}
\hline \multicolumn{3}{|c|}{$\begin{array}{c}\text { Near-surface } \\
\text { photodegradation }\end{array}$} & \multicolumn{7}{|c|}{ Biodegradation } \\
\hline & & & \multicolumn{2}{|c|}{ Sediments } & \multicolumn{2}{|r|}{ Water } & \multicolumn{3}{|c|}{ Soil } \\
\hline $\begin{array}{l}\mathrm{K}_{\text {pho,nearsur }} \\
\left(\mathrm{d}^{-1}\right)\end{array}$ & & Reference & $\begin{array}{l}K_{\text {bio,sed }} \\
\left(d^{-1}\right)\end{array}$ & Reference & $\begin{array}{l}\mathrm{K}_{\text {bio,wat }}\left(\mathrm{d}^{-}\right. \\
\left.{ }^{1}\right)\end{array}$ & Reference & $\begin{array}{l}K_{\text {bio,soil }} \\
\left(d^{-1}\right)\end{array}$ & \multicolumn{2}{|c|}{ Reference } \\
\hline 1642 & & $\begin{array}{l}\text { Brooke et al. } \\
(2004)\end{array}$ & Negligible & $\begin{array}{l}\text { Avendano et } \\
\text { al. (2015) }\end{array}$ & Negligible & $\begin{array}{l}\text { Avendano } \\
\text { et al. (2015) }\end{array}$ & Negligible & & $\begin{array}{l}\text { ivendano et } \\
\text { l. }(2015)\end{array}$ \\
\hline \multicolumn{10}{|c|}{ Table S15. TCS degradation rates. } \\
\hline \multirow{2}{*}{\multicolumn{3}{|c|}{$\begin{array}{c}\text { Near-surface } \\
\text { photodegradation }\end{array}$}} & \multicolumn{7}{|c|}{ Biodegradation } \\
\hline & & & \multicolumn{2}{|c|}{ Sediments } & \multicolumn{2}{|r|}{ Water } & \multicolumn{3}{|c|}{ Soil } \\
\hline $\begin{array}{l}\mathrm{K}_{\text {pho,nearsur }} \\
\left(\mathrm{d}^{-1}\right)\end{array}$ & & Reference & $\begin{array}{l}K_{\text {bio,sed }} \\
\left(d^{-1}\right)\end{array}$ & Reference & $\begin{array}{l}\mathrm{K}_{\text {bio,wat }} \\
\left(\mathrm{d}^{-1}\right)\end{array}$ & Reference & $\begin{array}{l}\begin{array}{l}K_{\text {bio,soil }} \\
\left(d^{-1}\right)\end{array} \\
\end{array}$ & & Reference \\
\hline $\begin{array}{l}23.1 \\
115.52\end{array}$ & - & $\begin{array}{l}\text { Baena- } \\
\text { Nogueras et } \\
\text { al. }(2017)\end{array}$ & $\begin{array}{l}7.2 \mathrm{E}-03 \\
6.36 \mathrm{E}-02\end{array}$ & $\begin{array}{l}\text { Wu et al. } \\
(2015 a)\end{array}$ & Negligible & $\begin{array}{l}\text { Wu et al. } \\
(2015 a)\end{array}$ & $3.85 \mathrm{E}-02$ & & $\begin{array}{l}\text { Wu et al. } \\
(2015 \mathrm{a})\end{array}$ \\
\hline 23.1 & & $\begin{array}{l}\text { Koumaki et } \\
\text { al. (2015) } \\
\text { Durán- }\end{array}$ & $\begin{array}{l}\text { Negligible } \\
\text { (an) }\end{array}$ & $\begin{array}{l}\text { Koumaki et } \\
\text { al. (2018) }\end{array}$ & $1.92 \mathrm{E}-02$ & $\begin{array}{l}\text { Baena-Nogueras } \\
\text { et al. (2017) }\end{array}$ & $\begin{array}{l}4.42 \mathrm{E}-02 \\
5.48 \mathrm{E}-02\end{array}$ & - & $\begin{array}{l}\text { Xu et al. } \\
(2009)\end{array}$ \\
\hline 3.15 & & $\begin{array}{l}\text { Álvarez et al. } \\
(2015)\end{array}$ & $\begin{array}{l}1.22 \mathrm{E}-02- \\
1.29 \mathrm{E}-02\end{array}$ & $\begin{array}{l}\text { NICNAS } \\
(2009)\end{array}$ & $\begin{array}{l}0.69 \mathrm{E}-02- \\
2.1 \mathrm{E}-02\end{array}$ & $\begin{array}{l}\text { Durán-Álvarez } \\
\text { et al. (2015) }\end{array}$ & $\begin{array}{l}9.78 \mathrm{E}-03 \\
1.74 \mathrm{E}-03 \\
1.2 \mathrm{E}-02\end{array}$ & $\begin{array}{l}- \\
-\end{array}$ & $\begin{array}{l}\text { Carr et al. } \\
(2011) \\
\text { Wu et al. }\end{array}$ \\
\hline 3.3 & & \multicolumn{3}{|c|}{ Latch et al. (2005) } & & & $2.17 \mathrm{E}-02$ & & $(2009)$ \\
\hline 69.31 & & \multicolumn{3}{|c|}{ Lindström et al. (2002) } & & & & & \\
\hline $\begin{array}{l}23.1 \\
34.66\end{array}$ & - & \multicolumn{3}{|c|}{ Singer et al. (2002) } & & & & & \\
\hline 69.31 & & \multicolumn{3}{|c|}{ Tixier et al. (2002) } & & & & & \\
\hline 4.62 & & \multicolumn{3}{|c|}{ Mezcua et al. (2004) } & & & & & \\
\hline 3.01 & & \multicolumn{3}{|c|}{ Martínez-Zapata et al. (2013) } & & & & & \\
\hline 231.04 & & \multicolumn{3}{|c|}{ Sanchez-Prado et al. (2006) } & & & & & \\
\hline 0.2 & & \multicolumn{3}{|c|}{ Wu et al. (2015a) } & & & & & \\
\hline
\end{tabular}




\section{SI.3 Model parameters and model inputs}

The environmental conditions used in RWQM1s1_MP are shown in Table S16. All values were taken from ARPA (Agenzia Regionale Protezione Ambiente) measurements databases for the year 2016. Regarding the CSPM, the model layers were adapted to the stratigraphy of the various soils with the parameters shown in Table S17. Photodegradation in rice paddies was assumed to be negligible due the sediment in suspension and plants shading. Eventual surface runoff of water was not modeled.

Table S16. Measurements and parameters used to characterize environmental conditions for the RWQM1s1_MP model

\begin{tabular}{|c|c|c|}
\hline Parameter & Source & Notes \\
\hline Wind speed at $10 \mathrm{~m}$ above ground & ARPA & Hourly measurements \\
\hline Air temperature & ARPA & Hourly measurements \\
\hline Sunlight intensity & ARPA & Hourly measurements \\
\hline Water temperature & ARPA & Monthly measurements at end of canal \\
\hline $\mathrm{pH}$ & ARPA & $\begin{array}{l}\text { Canal measurements average } \pm 1 \text { daily fluctuation (Simonsen } \\
\text { and Harremoës, 1978) }\end{array}$ \\
\hline TWW entering the canal & $\begin{array}{l}\text { Mazzini et al. } \\
\text { (2013) }\end{array}$ & Daily flow variations and rain events neglected \\
\hline TWW CECs concentrations & $\begin{array}{l}\text { Castiglioni et al. } \\
\text { (2018a, 2018b) }\end{array}$ & $\begin{array}{l}\text { Converted dissolved to total concentrations thanks to } \\
\text { equations in Chapra (1997) }\end{array}$ \\
\hline $\begin{array}{l}\text { Algae, heterotrophs and nitrifying } \\
\text { bacteria concentrations }\end{array}$ & & Initially left as default and then calibrated \\
\hline $\begin{array}{l}\text { Algae and bacterial growth } \\
\text { parameters }\end{array}$ & $\begin{array}{l}\text { Vanrollenghem } \\
\text { et al. (2001) }\end{array}$ & \\
\hline Phosphorous sorption and desorption & Chapra (1997) & \\
\hline
\end{tabular}


Table S17. Environmental parameters and sources used for the CSPM. LOSAN is a publicly available soil database provided by ERSAF (Ente Regionale per i Servizi all'Agricoltura e alle Foreste), CRA-CMA stands for Unità di Ricerca per la Climatologia e la Meteorologia applicate all'Agricoltura

\begin{tabular}{|c|c|c|}
\hline Parameter & Source & Notes \\
\hline Soil organic carbon & LOSAN & \\
\hline Soil layer $\mathrm{pH}$ & LOSAN & \\
\hline FC and PWP & LOSAN & Estimated from granulometries using correlations by Rawls et al. (1982) \\
\hline Soil layers bulk density & LOSAN & $\begin{array}{l}\text { Estimated from horizon-specific pedo-transfer functions from } \\
\text { SOILQUALIMON report (Brenna et al., 2010) }\end{array}$ \\
\hline Air temperature & ARPA & \\
\hline Rainfall & ARPA & \\
\hline Relative humidity & ARPA & \\
\hline Potential evaporation & CRA-CMA & $\begin{array}{l}\text { Obtained thanks to correction of potential evapotranspiration using } \mathrm{K}_{\mathrm{c}, \text { ini }} \\
\text { (1.05 rice, } 0.3 \text { other crops) (Legind et al., 2012; Polesel et al., 2015; Allen } \\
\text { et al., 1998) }\end{array}$ \\
\hline Soil layer temperature & CRA-CMA & $\begin{array}{l}\text { Extrapolated from measurements at depths of } 10 \text { and } 50 \mathrm{~cm} \text { thanks to the } \\
\text { sinusoidal functions in Xing and Spitler (2017). }\end{array}$ \\
\hline
\end{tabular}

\section{SI.3.1 Soil properties}

Table S18. Modeled soil properties.

\begin{tabular}{|c|c|c|c|c|c|}
\hline $\begin{array}{l}\text { Horizon bottom depth } \\
(\mathrm{cm})\end{array}$ & $\mathrm{pH}$ & $\begin{array}{l}\text { Organic carbon } \\
(\%)\end{array}$ & $\begin{array}{l}\text { Field capacity } \\
(\mathrm{L} / \mathrm{L})\end{array}$ & $\begin{array}{l}\text { Wilting point } \\
(\mathrm{L} / \mathrm{L})\end{array}$ & $\begin{array}{l}\text { Bulk density } \\
(\mathrm{g} / \mathrm{cm} 3)\end{array}$ \\
\hline \multicolumn{6}{|c|}{ Soil 1: silage maize and ryegrass } \\
\hline 13 & 7.3 & 4.9 & 0.36 & 0.14 & 1.09 \\
\hline 38 & 6.9 & 0.64 & 0.23 & 0.10 & 1.52 \\
\hline 60 & 7.8 & 0.64 & 0.31 & 0.13 & 1.32 \\
\hline 75 & 7.6 & 0.5 & 0.38 & 0.21 & 1.80 \\
\hline 100 & 7.5 & 0.37 & 0.32 & 0.14 & 1.59 \\
\hline \multicolumn{6}{|c|}{ Soil 2: silage maize and ryegrass, winter wheat } \\
\hline 20 & 6.6 & 1.27 & 0.24 & 0.09 & 1.45 \\
\hline 40 & 6.6 & 1.27 & 0.24 & 0.09 & 1.45 \\
\hline 60 & 6.7 & 0.16 & 0.18 & 0.09 & 1.48 \\
\hline 80 & 6.7 & 0.16 & 0.18 & 0.09 & 1.48 \\
\hline 100 & 6.7 & 0.16 & 0.18 & 0.09 & 1.48 \\
\hline \multicolumn{6}{|c|}{ Soil 3: rice and ryegrass, winter wheat } \\
\hline 35 & 6.1 & 2 & 0.26 & 0.11 & 1.33 \\
\hline 45 & 6.9 & 0.72 & 0.21 & 0.08 & 1.49 \\
\hline 67.5 & 7.2 & 0.63 & 0.16 & 0.06 & 1.41 \\
\hline 90 & 7.2 & 0.63 & 0.16 & 0.06 & 1.41 \\
\hline 100 & 7.4 & 0.44 & 0.23 & 0.12 & 1.49 \\
\hline
\end{tabular}


Pseudo-steady state concentrations of the layers in each modeled soil were obtained with median concentration in TWW as irrigation concentration and median soil degradation rate and used as initial concentrations. For the crop rotation consisting of rice and ryegrass and winter wheat, the soil concentrations at the end of the rice and ryegrass years were used as represented the worst case soil concentration.

\section{SI.3.2 Plant parameters}

Table S19. Parameters used for crop modeling. Parameters not noted were left as default.

\begin{tabular}{|c|c|c|c|}
\hline & Value & Reference & Notes \\
\hline \multicolumn{4}{|l|}{ Maize } \\
\hline Irrigation & $400 \mathrm{~mm} /$ season & Borrelli et al. (2014) & \\
\hline Germination date & $20-05$ & Borrelli et al. (2014) & \\
\hline Harvest date & $30-09$ & Borrelli et al. (2014) & \\
\hline $\begin{array}{l}\text { Transpiration } \\
\text { coefficient }\end{array}$ & $60 \mathrm{~L} / \mathrm{kg}$ fw & Legind et al. (2012) & \\
\hline Water content roots & $0.84 \mathrm{~g} / \mathrm{g}$ & Wang et al. (1991) & \\
\hline Final root mass & $2.58 \mathrm{~kg} \mathrm{fw} / \mathrm{m}^{2}$ & Legind et al. (2012) & \\
\hline Growth rate & $0.0811 / \mathrm{d}$ & Legind et al. (2012) & \\
\hline Final stem mass & $3.61 \mathrm{~kg} \mathrm{fw} / \mathrm{m}^{2}$ & Legind et al. (2012) & \\
\hline Final leaf mass & $0.96 \mathrm{~kg} \mathrm{fw} / \mathrm{m}^{2}$ & Legind et al. (2012) & \\
\hline Final fruit mass & $1.78 \mathrm{~kg} \mathrm{fw} / \mathrm{m}^{2}$ & Legind et al. (2012) & \\
\hline Water content fruit & 0.76 & USDA (2018) & \\
\hline \multicolumn{4}{|l|}{ Ryegrass } \\
\hline Irrigation & $210 \mathrm{~mm} / \mathrm{season}$ & FAO (2007) & $\begin{array}{l}\text { Calculated subtracting rainfall from water } \\
\text { requirements }\end{array}$ \\
\hline Germination date & $\begin{array}{l}9-12 \text { with silage } \\
\text { maize }-30 / 10 \\
\text { with rice }\end{array}$ & $\begin{array}{l}\text { Borrelli et al. (2014), Nelli } \\
\text { and Sodi (2007) }\end{array}$ & \\
\hline Harvest date & $\begin{array}{l}14-05 \text { with silage } \\
\text { maize }-31 / 03 \\
\text { with rice }\end{array}$ & $\begin{array}{l}\text { Borrelli et al. (2014), Nelli } \\
\text { and Sodi (2007) }\end{array}$ & \\
\hline Final root mass & $2.35 \mathrm{~kg} \mathrm{fw} / \mathrm{m}^{2}$ & & $\begin{array}{l}\text { Assumed equal to winter wheat since same } \\
\text { family (Poaceae) }\end{array}$ \\
\hline Final stem mass & $1.8 \mathrm{~kg} \mathrm{fw} / \mathrm{m}^{2}$ & $\begin{array}{l}\text { Tabaglio et al. (2007), } \\
\text { Abraha and Savage (2008) }\end{array}$ & Calculated assuming water content $=0.8$ \\
\hline Final leaf mass & $2.2 \mathrm{~kg} \mathrm{fw} / \mathrm{m}^{2}$ & $\begin{array}{l}\text { Tabaglio et al. (2007), } \\
\text { Abraha and Savage (2008) }\end{array}$ & Calculated assuming water content $=0.8$ \\
\hline Initial fruit mass & $1 \mathrm{E}-05 \mathrm{~kg} \mathrm{fw} / \mathrm{m}^{2}$ & Martiniello (1999) & To halt fruit development \\
\hline
\end{tabular}

Table S19. Cont. 


\begin{tabular}{|c|c|c|c|}
\hline \multicolumn{4}{|l|}{ Winter wheat } \\
\hline Irrigation & $100 \mathrm{~mm} / \mathrm{season}$ & Polesel et al. (2015) & \\
\hline Germination date & $1-03$ & Legind et al. (2012) & \\
\hline Harvest date & $15-07$ & Legind et al. (2012) & \\
\hline Final root mass & $2.35 \mathrm{~kg} \mathrm{fw} / \mathrm{m}^{2}$ & Legind et al. (2012) & \\
\hline Final stem mass & $0.78 \mathrm{~kg} \mathrm{fw} / \mathrm{m}^{2}$ & Legind et al. (2012) & \\
\hline Final leaf mass & $1.81 \mathrm{~kg} \mathrm{fw} / \mathrm{m}^{2}$ & Legind et al. (2012) & \\
\hline Final fruit mass & $1.45 \mathrm{~kg} \mathrm{fw} / \mathrm{m}^{2}$ & Legind et al. (2012) & \\
\hline \multicolumn{4}{|l|}{ Rice } \\
\hline Irrigation & $21.6 \mathrm{~mm} /$ day & Nelli and Sodi (2007) & \\
\hline Germination date & $6-04$ & Nelli and Sodi (2007) & \\
\hline Harvest date & $30-09$ & Nelli and Sodi (2007) & \\
\hline $\begin{array}{l}\text { Transpiration } \\
\text { coefficient }\end{array}$ & 52 & Van der Vorm (1980) & \\
\hline $\begin{array}{l}\text { Roots/Stem/Leaf } \\
\text { growth rate }\end{array}$ & 0.068 & $\begin{array}{l}\text { Confalonieri and Bocchi } \\
(2005)\end{array}$ & \\
\hline Fruit growth rate & 0.13 & & $\begin{array}{l}\text { Doubled compared to plant growth rate } \\
\text { similarly to what observed for winter wheat } \\
\text { and to match model ripening with agronomic } \\
\text { data }\end{array}$ \\
\hline Final root mass & 3.30 & $\begin{array}{l}\text { Confalonieri and Bocchi } \\
(2005)\end{array}$ & \\
\hline Final stem mass & 1.76 & $\begin{array}{l}\text { Confalonieri and Bocchi } \\
\text { (2005) }\end{array}$ & \\
\hline Final leaf mass & 1.92 & $\begin{array}{l}\text { Confalonieri and Bocchi } \\
(2005)\end{array}$ & \\
\hline Final fruit mass & 0.94 & $\begin{array}{l}\text { Confalonieri and Bocchi } \\
(2005)\end{array}$ & \\
\hline Water content root & 0.95 & $\begin{array}{l}\text { Zhang and Webster } \\
\text { (2002); Henry et al. (2012) }\end{array}$ & $\begin{array}{l}\text { Calculated based on fresh weight } \\
\text { measurements and roots to shoots ratio }\end{array}$ \\
\hline Water content fruit & 0.23 & $\begin{array}{l}\text { Rice Knowledge Bank } \\
\text { (2017) }\end{array}$ & \\
\hline
\end{tabular}

The ratio of phloem to xylem flux for PAR, SMX, IBU and FUR was set to 0.05, a median value between day and night. For the other CECs such ratio was set to 0 as considered non phloem-systemic based on the distinction by Kleier and Hsu (1996) relying on CECs Kow and $\mathrm{pK}_{\mathrm{a}}$. The phloem systemicity of DCF and PFOA was treated as uncertain as potentially affected by plant-specific parameters. 


\section{SI.4 Uncertainty propagation}

The preliminary uncertainty analysis (UA) of the IUWS_MP model for traditional pollutants was carried out varying the parameters in Table S20. Parameters uncertainty was based on Reichert and Vanrollenghem (2001) considering two classes of confidence: poorly known parameters were varied by $50 \%$ (Class 2), while better known parameters were varied by $20 \%$ (Class 1). CBZ, DCF and TCS, CECs with different physicochemical characteristics, were chosen amongst the thirteen selected to be tested. Random parameters combinations were obtained through 1000 Latin hypercube samplings for each CEC.

Table S20. Uncertainty classes of parameters for the uncertainty analysis of the traditional pollutants submodel.

\begin{tabular}{lclc}
\hline Parameter & Class & Parameter & Class \\
\hline Heterotrophic bacteria input concentration & 2 & First stage nitrifiers (AOBs) input concentration & 2 \\
Phosphate adsorption rate & 2 & Algae input concentration & 2 \\
$\begin{array}{l}\text { Saturation coefficient for aerobic growth of } \\
\text { heterotrophs on dissolved organic substrate }\end{array}$ & 2 & Mean particle diameter & 2 \\
Slope & 1 & Saturation coefficient for growth of AOBs on & 2 \\
& & ammonia & \\
Maximum aerobic specific growth rate for & 1 & Manning n value & 1 \\
heterotrophic biomass & & & \\
Top canal width & 1 & Maximum aerobic specific growth rate for AOBs & 1 \\
Depth of canal filled to bank & 1 & & \\
\hline
\end{tabular}

Successively, the uncertainty regarding the organic micropollutants IUWS_MP submodel and CSPM parameters on CECs concentrations were assessed through a Monte Carlo UA varying the parameters in Table S21. When no anoxic sediment biodegradation rates were found in literature, the aerobic values decreased by an order of magnitude were used. In case only one or two values were found, uniform distributions were used considering either a $10 \%$ variation or the range between the two values. The uncertainty of IUWS_MP was estimated thanks to 1000 runs for each water water withdraw scenario. The choice of the number of CSPM runs was based on the comparison of the percentiles from simulations consisting of an increasing amount of runs to the ones resulting from a 5000 runs simulation. As the percentiles from a 2000 runs simulation with Latin hypercube sampling differed negligibly from the 5000 runs simulation, the mentioned settings were chosen for the remaining simulations. 
Table S21. Varied parameters during the IUWS_MP and CSPM Monte Carlo uncertainty analyses

\begin{tabular}{|c|c|c|c|}
\hline Parameter & Distribution & Source & Notes \\
\hline TWW CEC concentrations & Triangular & $\begin{array}{l}\text { Castiglioni et al. (2018a, } \\
\text { 2018b) }\end{array}$ & $\begin{array}{l}\text { Inf: minimum value/LOD } \\
\text { Mode: median value/0.5*LOQ } \\
\text { Sup: maximum value/LOQ }\end{array}$ \\
\hline $\begin{array}{l}\text { Water aerobic biodegr. rate } \\
\text { Sediment aerobic biodeg. rate } \\
\text { Sediment anoxic biodegr. rate } \\
\text { Soil dissipation rate } \\
\text { Photodegradation rate }\end{array}$ & $\begin{array}{l}\text { Empirical, } \\
\text { triangular }\end{array}$ & Tables S4 - S16 & $\begin{array}{l}\text { Choice based on the quantity of } \\
\text { experimental values found. Values } \\
\text { outside } 1.5 * \mathrm{IQR} \text { (interquartile range) } \\
\text { considered as outliers. Triangular } \\
\text { distributions based on extreme values } \\
\text { and medians }\end{array}$ \\
\hline $\begin{array}{l}\mathrm{pK}_{\mathrm{a}} \\
\text { Kow }\end{array}$ & & & \\
\hline $\begin{array}{l}\text { Solubility } \\
\text { Vapor pressure } \\
\text { KHSA }_{\text {Kaw }} \\
\text { (only perfluorinated chemicals) }\end{array}$ & $\begin{array}{l}\text { Empirical, } \\
\text { triangular }\end{array}$ & Table S3 & $\begin{array}{l}\text { Choice based on the quantity of } \\
\text { experimental values found }\end{array}$ \\
\hline Irrigation concentration & Triangular & Surface water model & $\begin{array}{l}\text { Inf: } 2.5^{\text {th }} \text { percentile canal conc. } \\
\text { Mode: modal canal conc. } \\
\text { Sup: } 97.5^{\text {th }} \text { percentile canal conc. }\end{array}$ \\
\hline $\begin{array}{l}\mathrm{pH} \text { in cytosol } \\
\mathrm{pH} \text { in vacuole } \\
\mathrm{pH} \text { in phloem } \\
\mathrm{pH} \text { in xylem }\end{array}$ & Uniform & $\begin{array}{l}\text { Felle (2001), Felle et al. } \\
(2005) \text {, Johannes et al. } \\
\text { (2001), Tournaire-Roux et } \\
\text { al. (2003) }\end{array}$ & $\begin{array}{l}10 \% \text { variation is comparable to } \\
\text { observed fluctuations }\end{array}$ \\
\hline $\begin{array}{l}\text { Transpiration coeff. } \\
\text { Root mass }\end{array}$ & & & \\
\hline $\begin{array}{l}\text { Root growth rate } \\
\text { Stem growth rate } \\
\text { Leaves growth rate } \\
\text { Fruits growth rate }\end{array}$ & Uniform & & $\begin{array}{l}\text { Variation equal to } 10 \% \text { to avoid } \\
\text { numerical errors }\end{array}$ \\
\hline $\begin{array}{l}\text { Arrhenius temperature } \\
\text { correction coeff. }\end{array}$ & Lognormal & EFSA (2007) & $\begin{array}{l}\text { Median: } 1.099 \\
95^{\text {th }} \text { percentile: } 1.144\end{array}$ \\
\hline
\end{tabular}

Other parameters were varied during the analysis of specific CECs to either prevent numerical errors (SMX, PAR, E2), include uncertainty (PFOA, DCF) and improve model results (CLA, PFOS):

- $\quad$ PFOA and DCF phloem flux was set in $50 \%$ of the runs as 0 ;

- CLA's Koc was set to $10176 \mathrm{~L} / \mathrm{kg}$ to match the value from the equations in Franco and Trapp (2008);

- SMX and PFOS KOC was varied as the other physicochemical properties; 
- The soil structure during PAR simulations was modified to 3 layers of $33 \mathrm{~cm}$ whose soil properties were calculated as weighted average of the original layers. The dissipation rate was, also, set to the minimum value and the Koc from ECHA (2006) was used;

- The dissipation rate of $\mathrm{E} 2$ was limited to $1 \mathrm{~d}^{-1}$.

Successively, the monthly medians of the total CECs concentrations taken at four locations along the canal were fitted with a first-order dissipation rate thanks to the use of Matlab R2016a and the estimated traveling times provided by IUWS_MP model. Yearly best- and worst-case attenuation rates were calculated for all the modeled CECs and compared to literature as a further validation.

Such attenuation rates and influent CECs concentrations (Castiglioni et al., 2018a) were used to estimate the expected concentrations along the canal in case of the absence of the upstream WWTP. Best- and worst-case scenarios were calculated respectively using low concentrations and high rates, and high concentrations and low rates. The median scenarios were obtained thanks to the median concentrations and the mean between the two attenuation rates.

The fruit CECs concentrations in case of the absence of the WWTP were estimated thanks to the expected median concentrations at the end of the canal which were used to reach a pseudo-steady state in the coupled soil-plant model. Successively, the median CECs concentration of the first layer at pseudo-steady state was multiplied by the median or the $97.5^{\text {th }}$ percentile BCFs, calculated from the previous Monte Carlo uncertainty analyses, to estimate of the median and $97.5^{\text {th }}$ percentile fruit concentration. 


\section{SI.5 Sensitivity analyses (SA)}

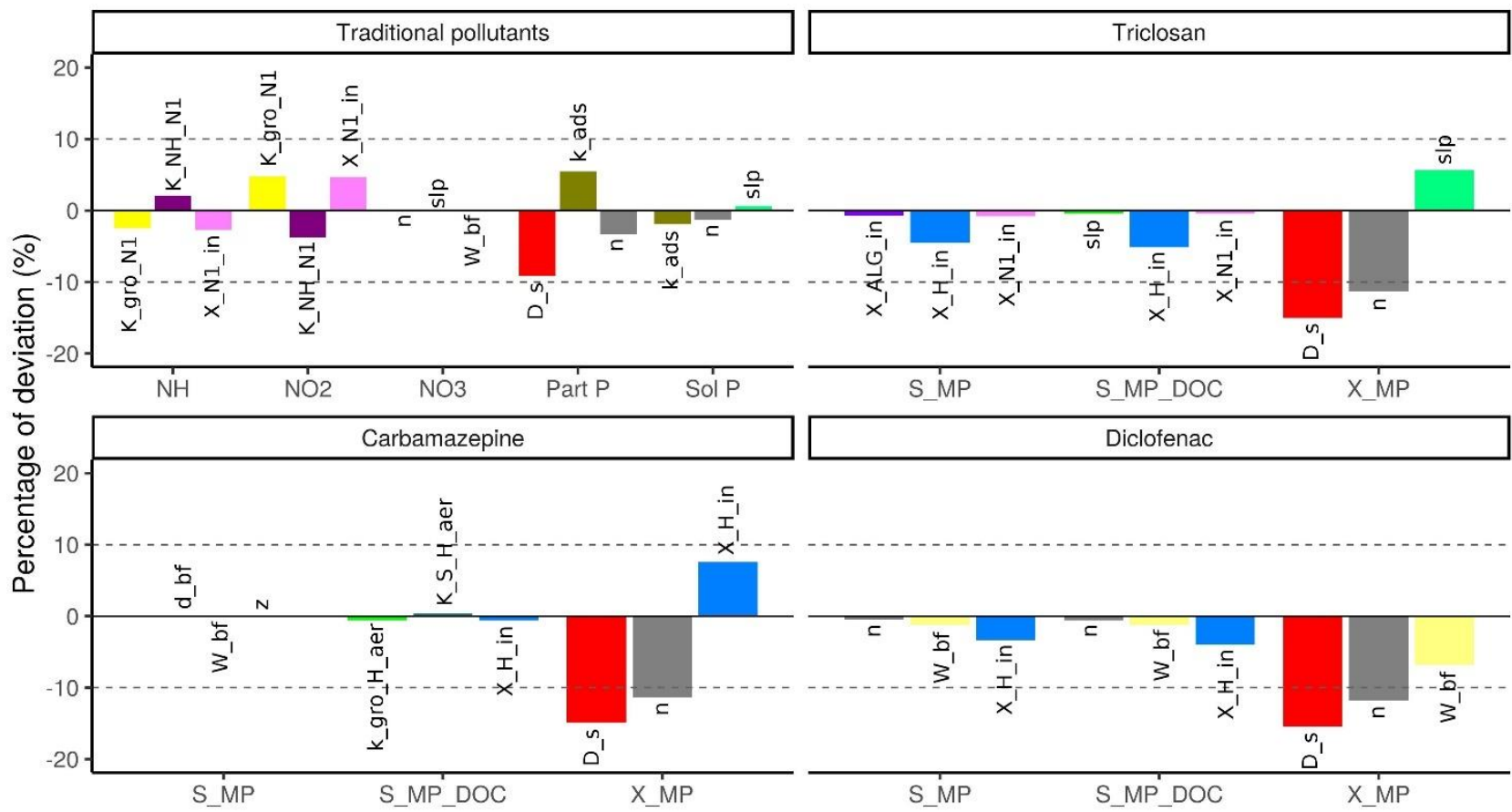

Figure S2. Deviation caused by increments of the parameters in the traditional pollutants submodel. S_MP, S_MP_DOC and X_MP indicate respectively the following fractions of a CEC: dissolved, sorbed on colloids and sorbed on TSS.

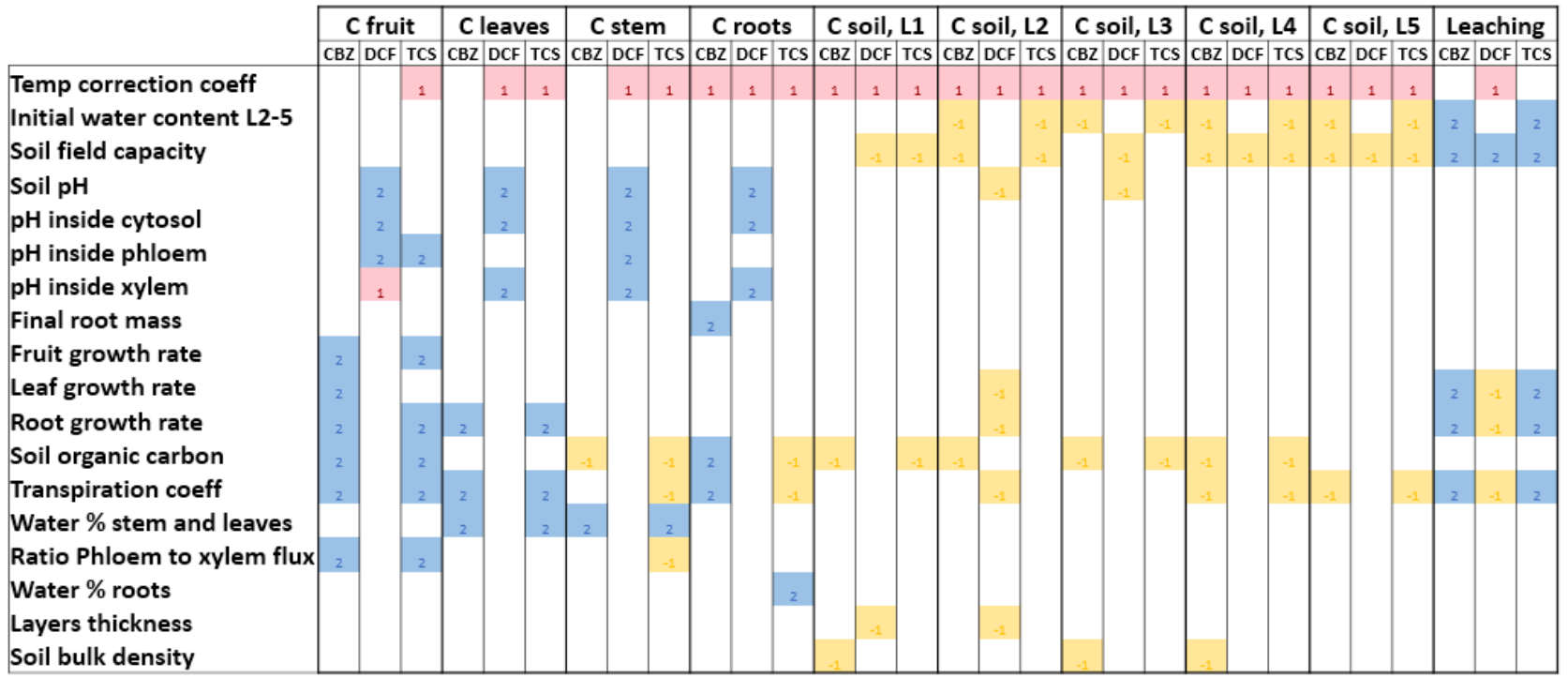

2 WITH and NO degradation

| 1 |Only WITH degradation

| -1 Only NO degradation

Figure S3. Coupled soil-plant model sensitive parameters in presence or absence of degradation. 


\section{SI.6 Fate analysis}

\section{SI.6.1 Traditional pollutants}
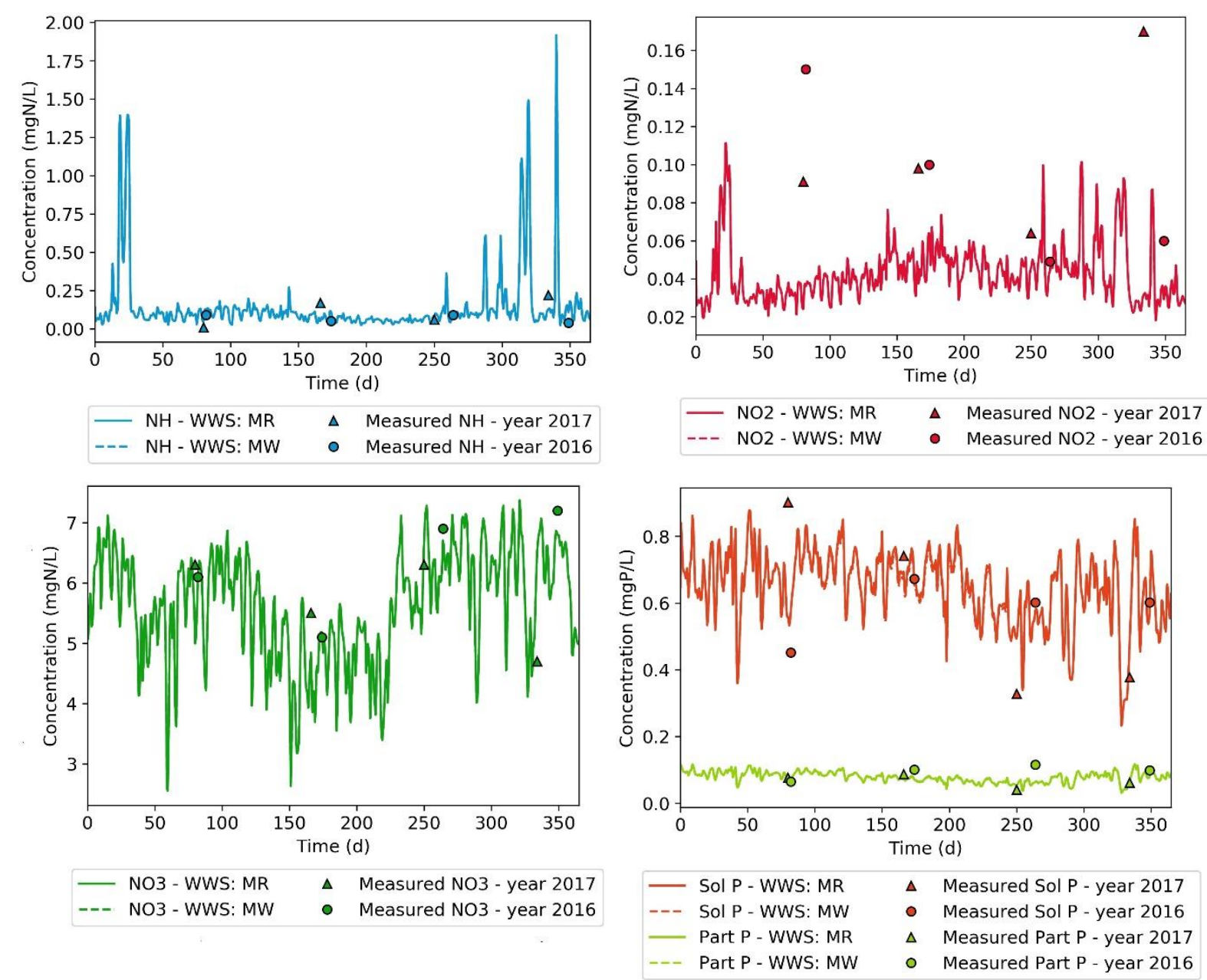

Figure S4. Traditional pollutants calibrated concentrations and measured values in canal. $\mathrm{NH}=$ ammonium, $\mathrm{NO} 2=$ nitrite, $\mathrm{NO} 3$ = nitrate, $\mathrm{Sol} \mathrm{P}=$ soluble phosphorus, $\mathrm{Part} \mathrm{P}=$ particulate phosphorus. 
SI.6.2 Uncertainty of CECs concentrations in canal

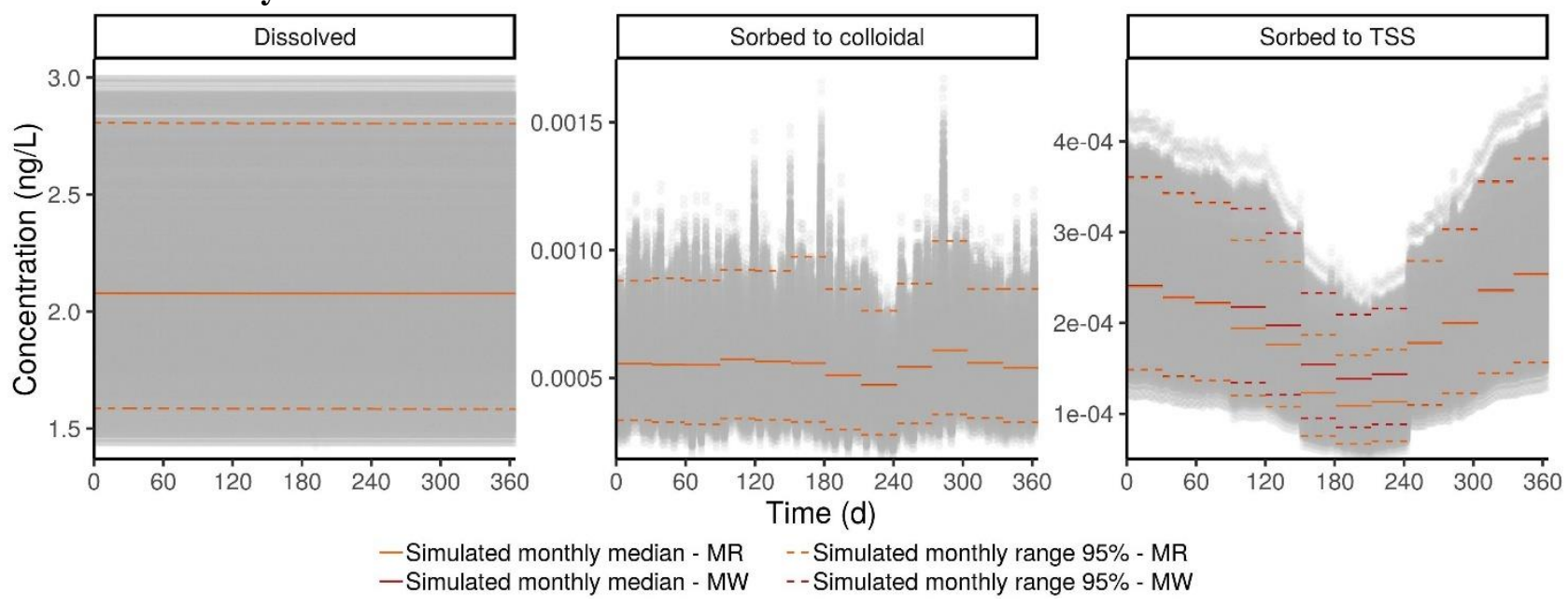

Figure S5. PFOS midday predicted concentration ranges. Days starting from January 1st until December 31st.

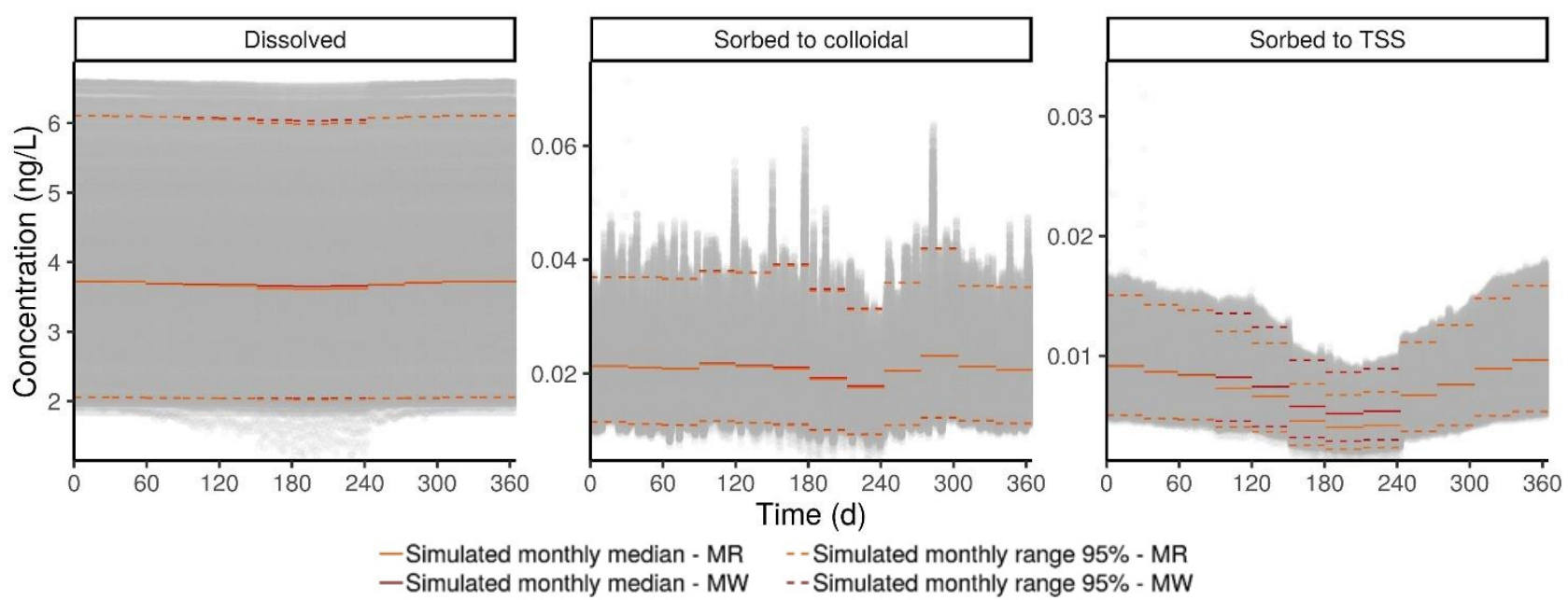

Figure S6. TCS midday predicted concentration ranges. Days starting from January 1st until December 31 st.
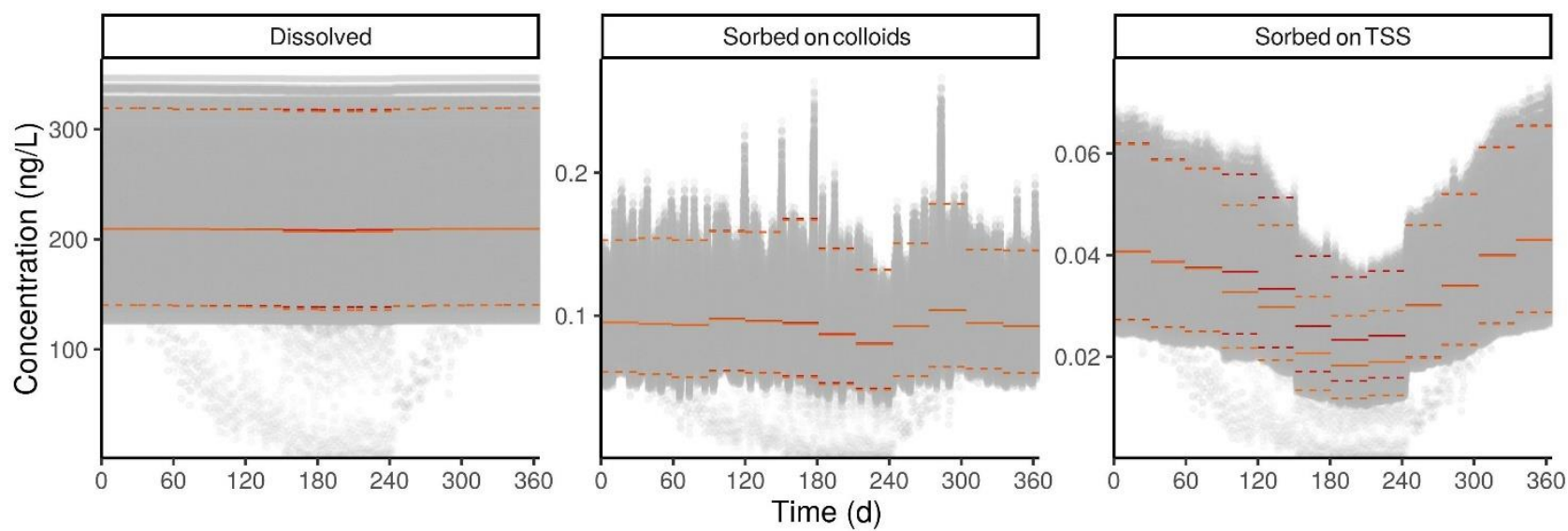

$\begin{array}{ll}\text { - Simulated monthly median - MR } & \text {--Simulated monthly range 95\% - MR } \\ \text { - Simulated monthly median - MW } & \text {--Simulated monthly range 95\% - MW }\end{array}$

Figure S7. CBZ midday predicted concentration ranges. Days starting from January 1st until December 31st. 

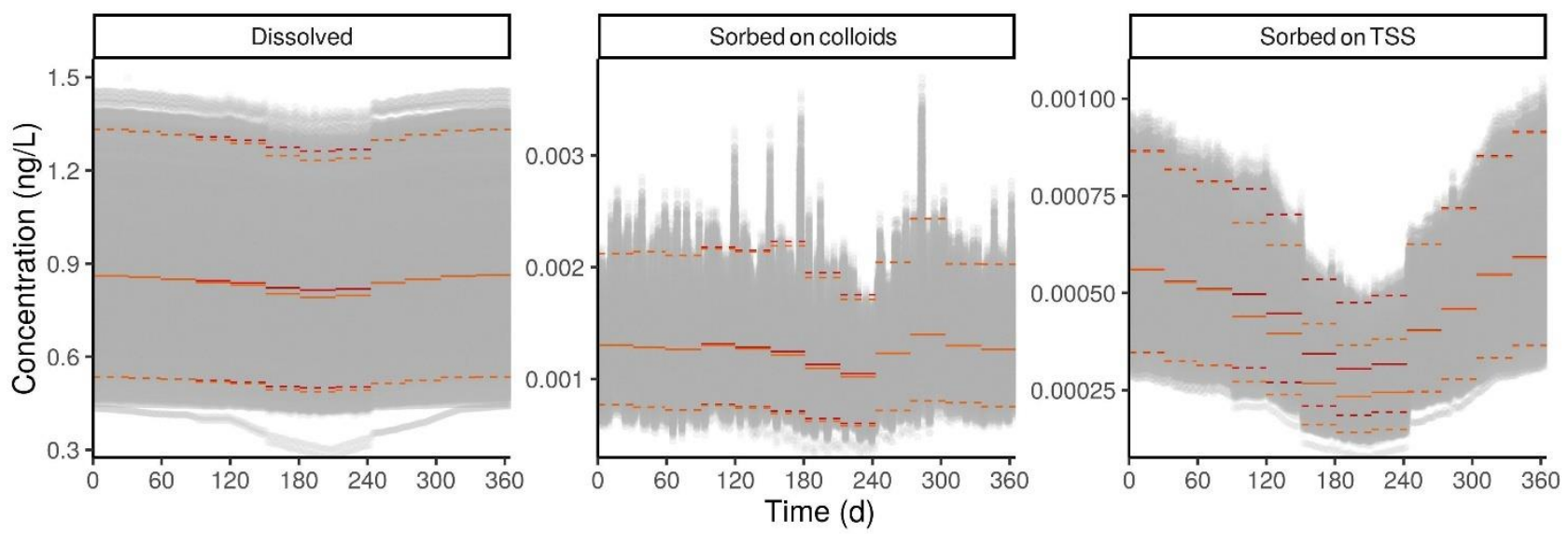

$\begin{array}{ll}\text { - Simulated monthly median - MR } & \text { - - Simulated monthly range 95\% - MR } \\ \text { - Simulated monthly median - MW } & \text { - - Simulated monthly range 95\% - MW }\end{array}$

Figure S8. E1 midday predicted concentration ranges. Days starting from January 1st until December 31st.
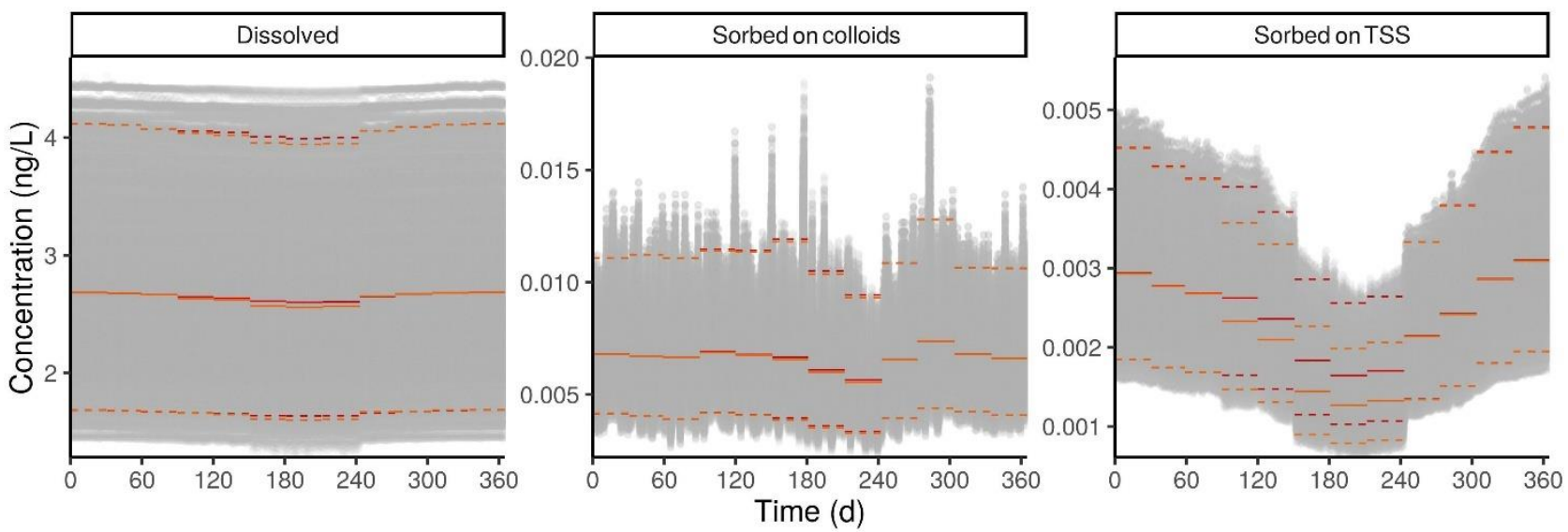

- Simulated monthly median - MR - - Simulated monthly range 95\% - MR

- Simulated monthly median - MW - - Simulated monthly range 95\% - MW

Figure S9. EE2 midday predicted concentration ranges. Days starting from January 1st until December 31st.

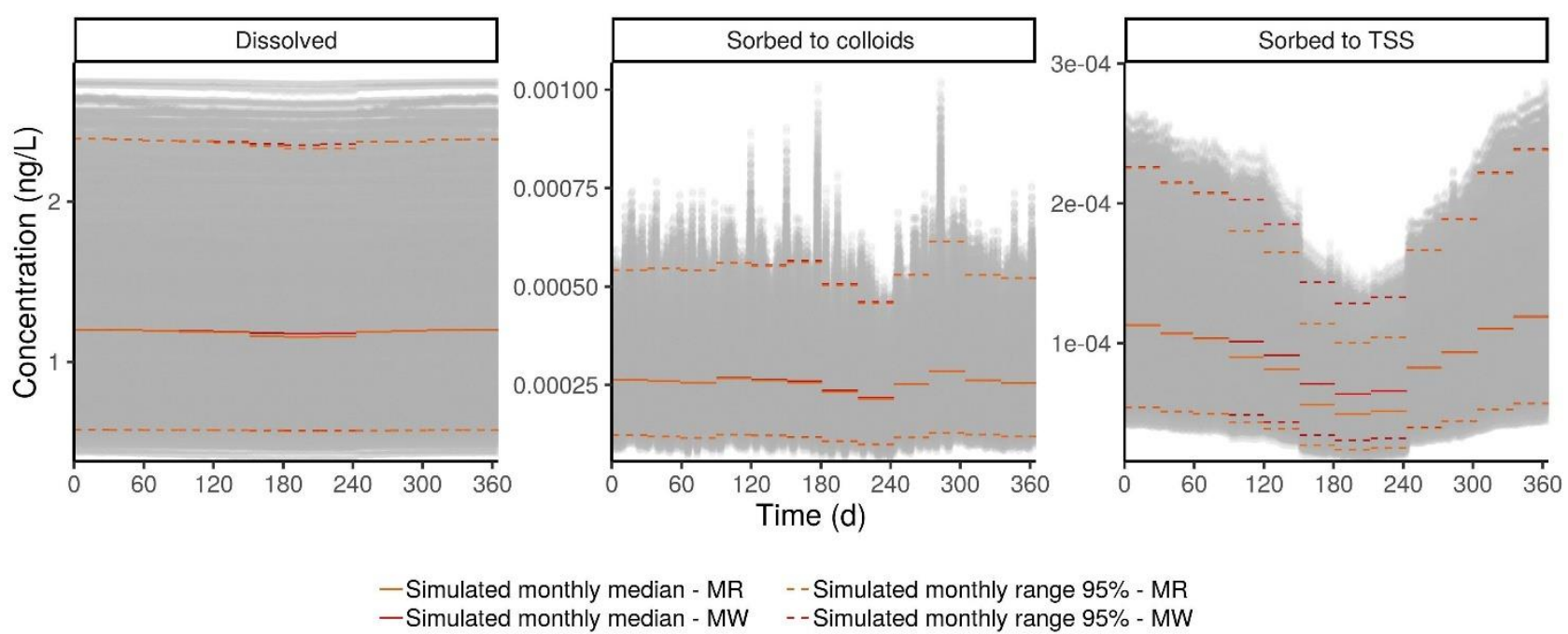

Figure S10. IBU midday predicted concentration ranges. Days starting from January 1st until December 31st. 

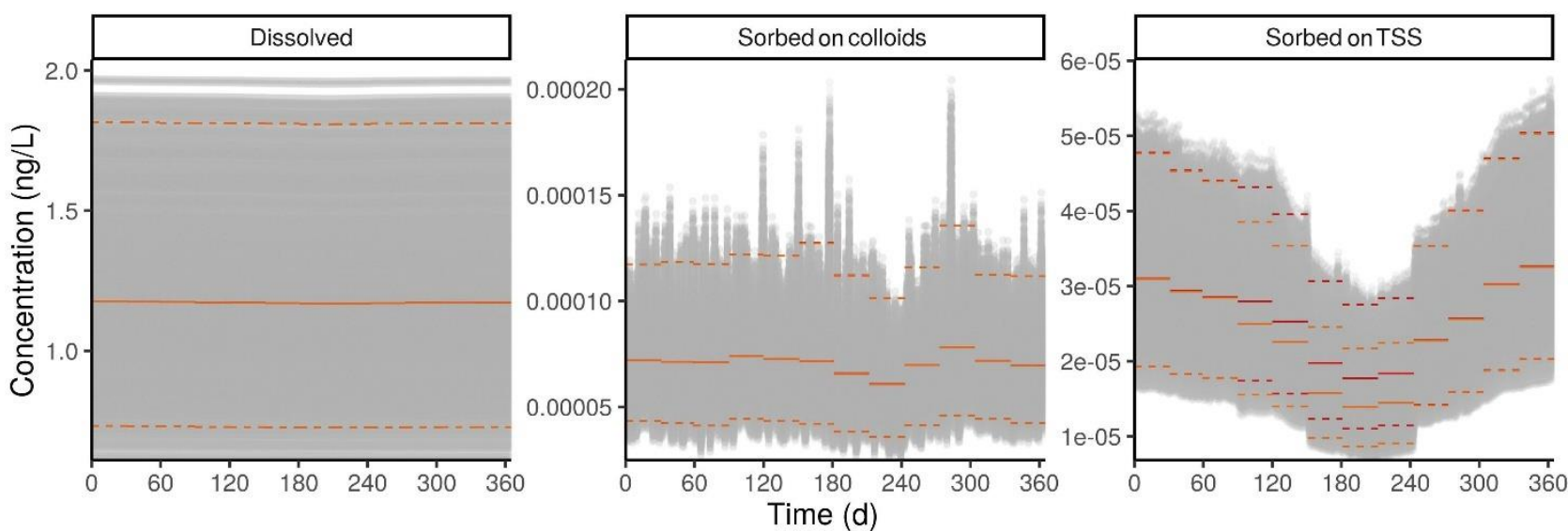

- Simulated monthly median - MR - - Simulated monthly range 95\% - MR

- Simulated monthly median - MW - - Simulated monthly range 95\% - MW

Figure S11. PAR midday predicted concentration ranges. Days starting from January 1st until December 31st.
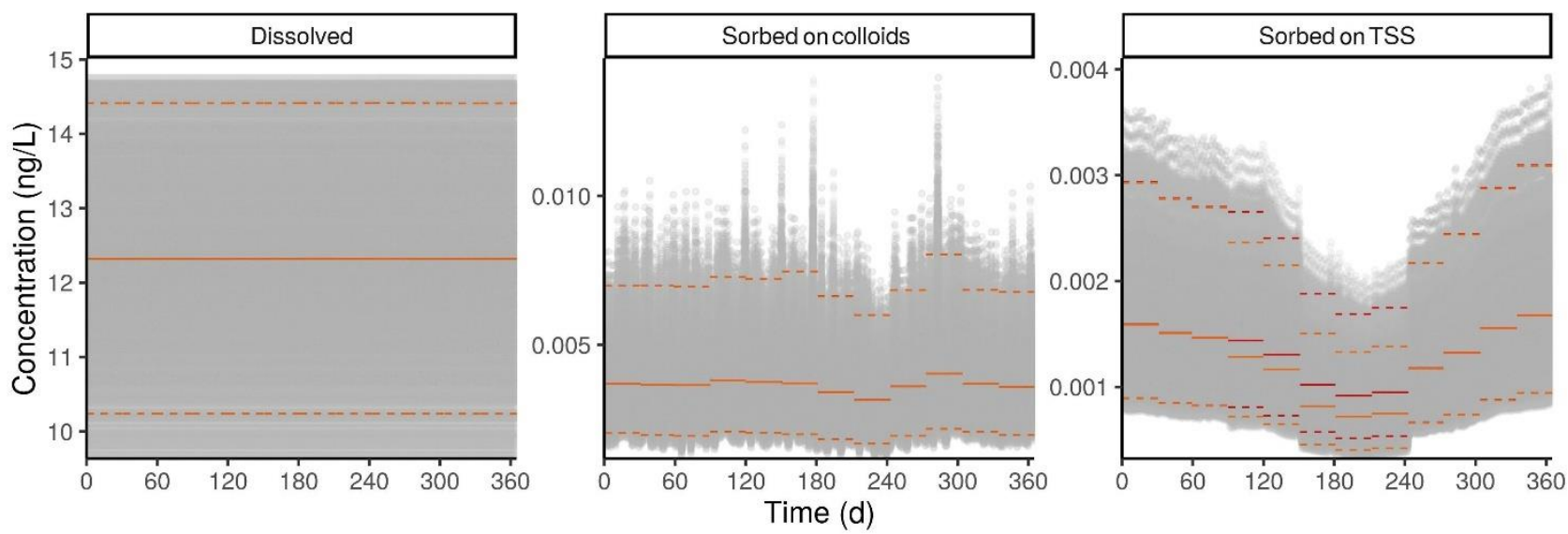

- Simulated monthly median - MR - - Simulated monthly range 95\% - MR

- Simulated monthly median - MW - - Simulated monthly range 95\% - MW

Figure S12. PFOA midday predicted concentration ranges. Days starting from January 1st until December 31st.
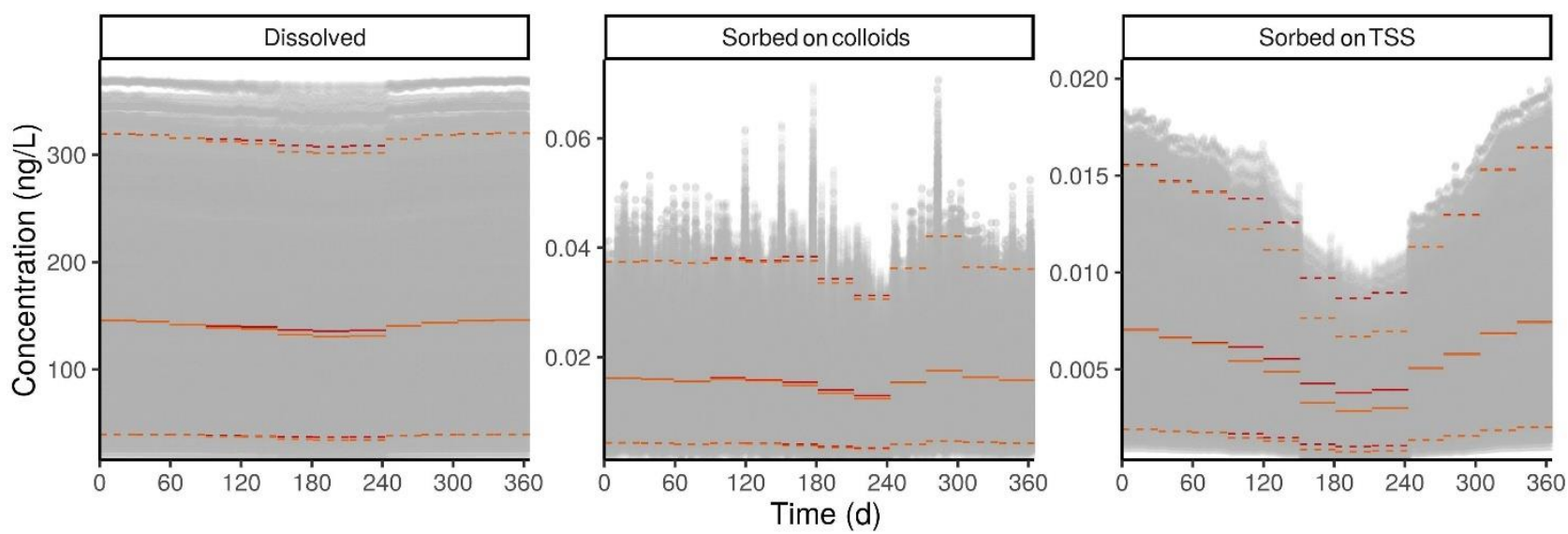

- Simulated monthly median - MR - - Simulated monthly range 95\% - MR

- Simulated monthly median - MW - - Simulated monthly range 95\% - MW

Figure S13. SMX midday predicted concentration ranges. Days starting from January 1st until December 31st. 

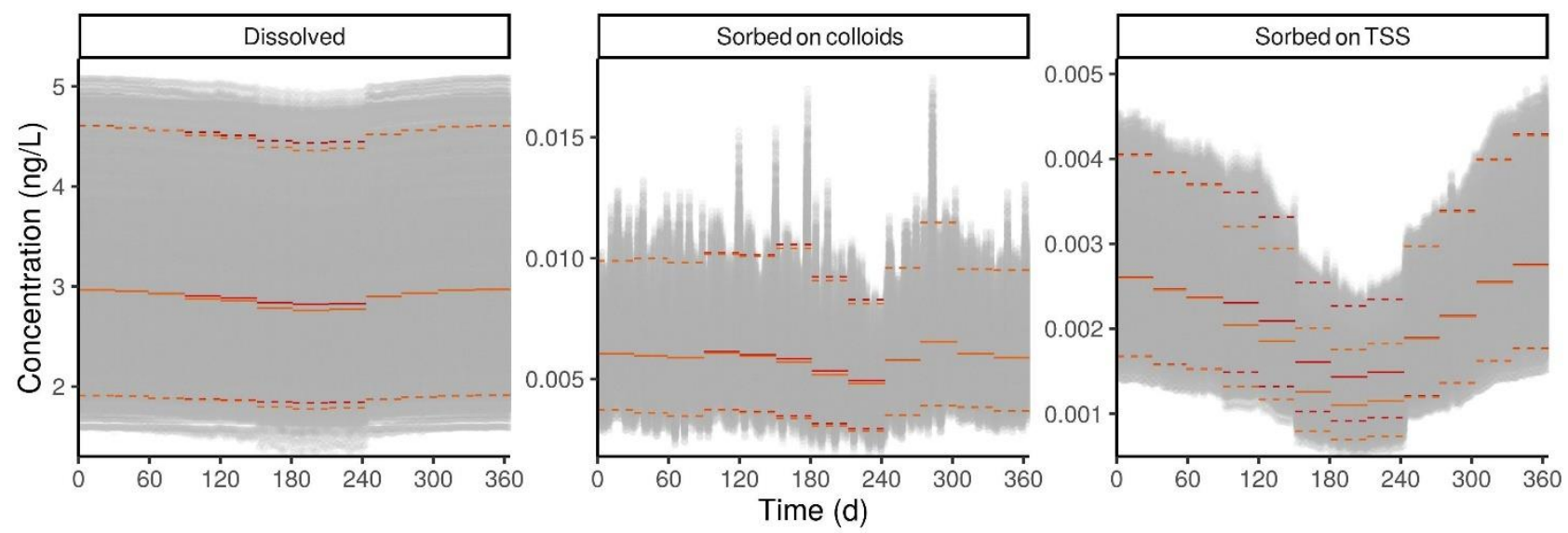

- Simulated monthly median - MR - - Simulated monthly range 95\% - MR

- Simulated monthly median - MW - - Simulated monthly range $95 \%$ - MW

Figure S14. E2 midday predicted concentration ranges. Days starting from January 1st until December 31st.

\section{SI.6.3 Attenuation along the canal}

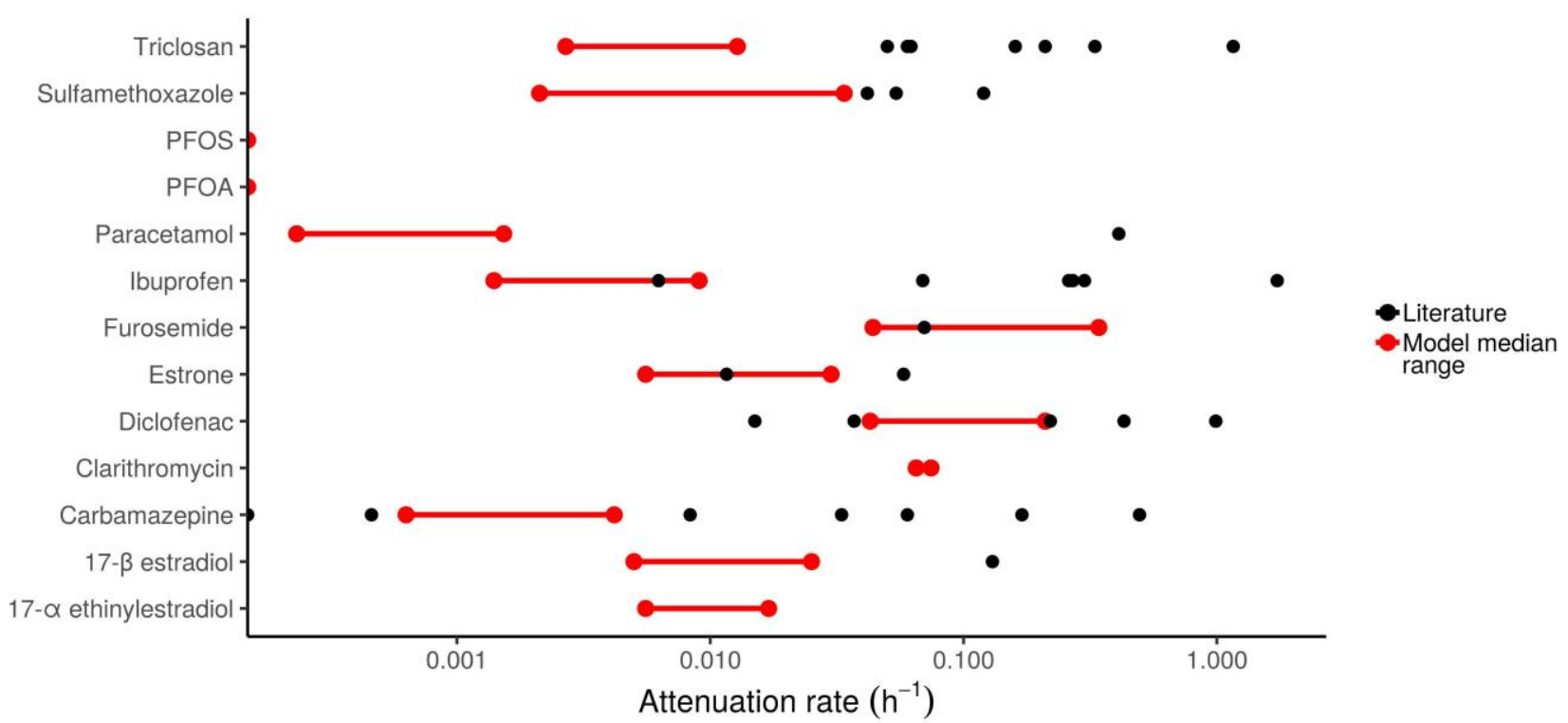

Figure S15. Predicted median attenuation rates compared to attenuation rates from literature. References: Acuña et al. (2015), Bester (2005), Fono et al. (2006), Guillet et al. (2019), Kunkel and Radke (2011), Lin et al. (2006), Morrall et al. (2004), Matamoros and Rodríguez (2017), Radke et al. (2010), Sabaliunas et al. (2003), Tixier et al. (2003), Williams et al. (2003), Writer et al. (2012, 2013). 
SI.6.4 Bioconcentration factors

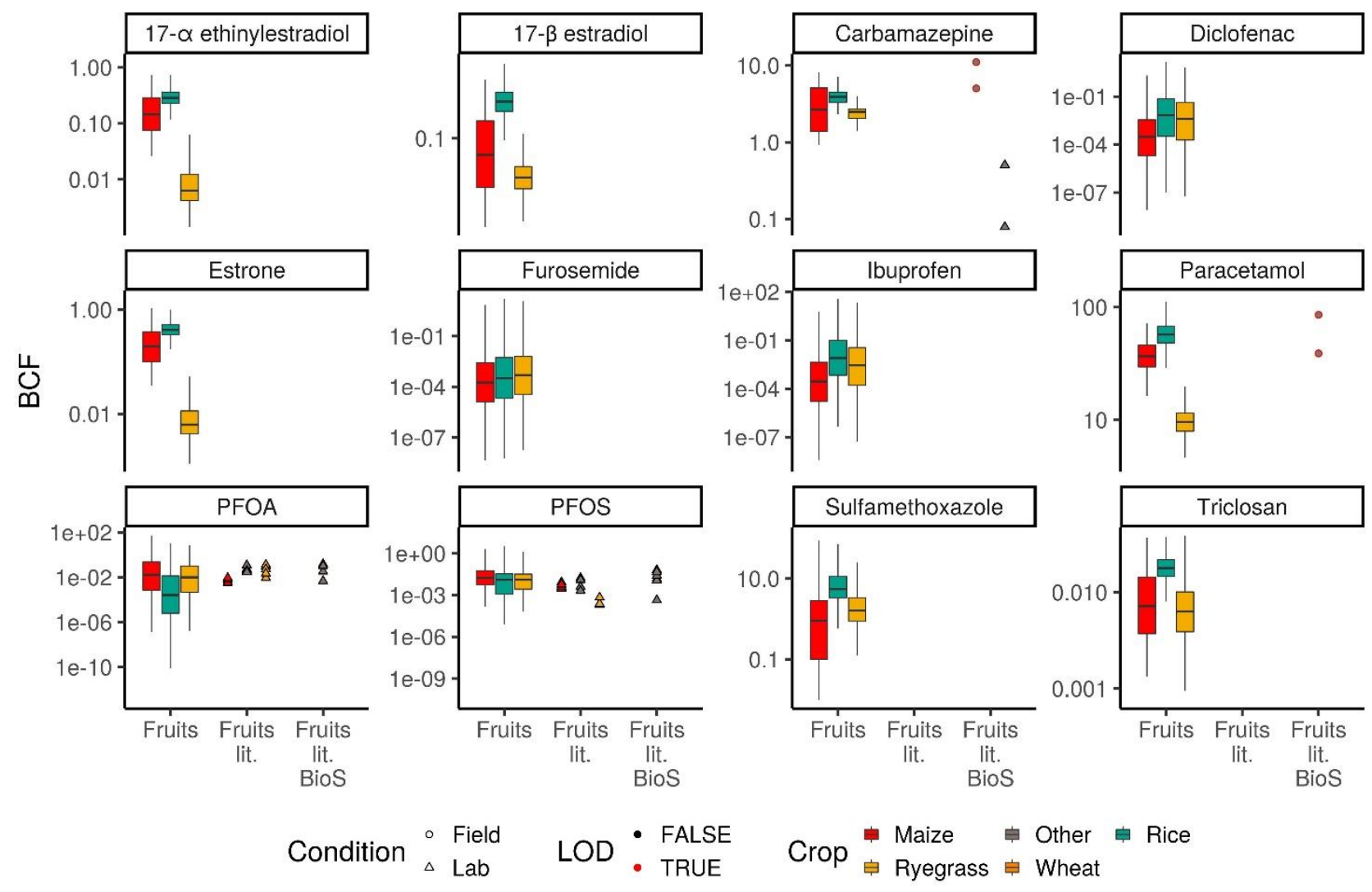

Figure S16. Fruit BCFs (gdw/gdw) for silage maize, winter wheat, ryegrass and rice with respect to maximum soil concentrations and literature (lit.) values. All simulated soils are shown. BioS indicates experimental studies conducted with the use of biosolids. Red borders indicate the use of an LOD value in the calculation of the BCF. References (including fruit BCFs in Figure 3): Blaine et al. (2013, 2014), Christou et al. (2017), Goldstein et al. (2014), Lechner and Knapp (2011), Mordechay et al. (2018), Navarro et al. (2017), Pannu et al. (2012), Prosser et al. (2014), Sabourin et al. (2012), Shenker et al. (2011), Stahl et al. (2009), Wen et al. (2014), Wu et al. (2010, 2012), Yager et al. (2014) 

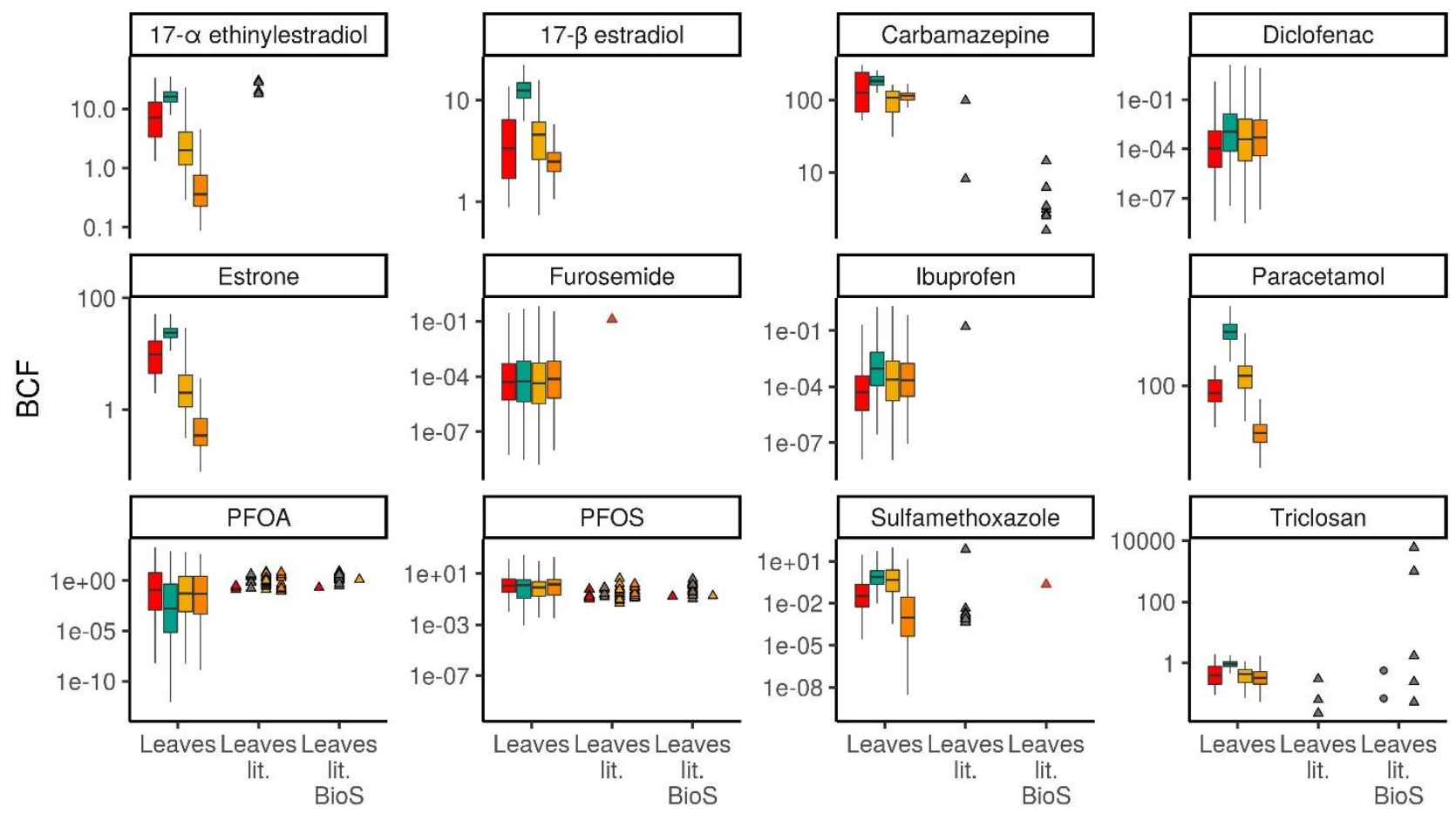

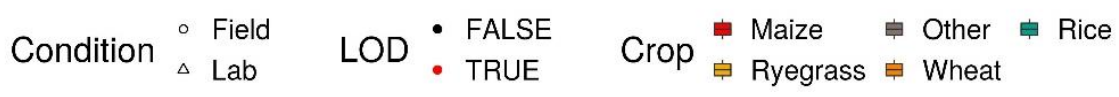

Figure S17. Leaf BCFs (gdw/gdw) for silage maize, winter wheat, ryegrass and rice with respect to maximum soil concentrations and literature (lit.) values. All simulated soils are shown. BioS indicates experimental studies conducted with the use of biosolids. Red borders indicate the use of an LOD value in the calculation of the BCF. References (including leaf BCFs in Figure 3): Aryal and Reinhold (2011), Bizkarguenaga et al. (2016), Blaine et al. (2013, 2014), Carter et al. (2014), Chitescu et al. (2012), Fu et al. (2016), Goldstein et al. (2014), Holling et al. (2012), Hurtado et al. (2017), Karnjanapiboonwong et al. (2011), Lechner and Knapp (2011), Macherius et al. (2012), Malchi et al. (2014), Mordechay et al. (2018), Navarro et al. (2017), Pannu et al. (2012), Prosser et al. (2014), Shenker et al. (2011), Stahl et al. (2009), Wen et al. (2014, 2016), Winker et al. (2010), Wu et al. (2010, 2012), Yoo et al. (2011), Zhao et al. (2014, 2017). 


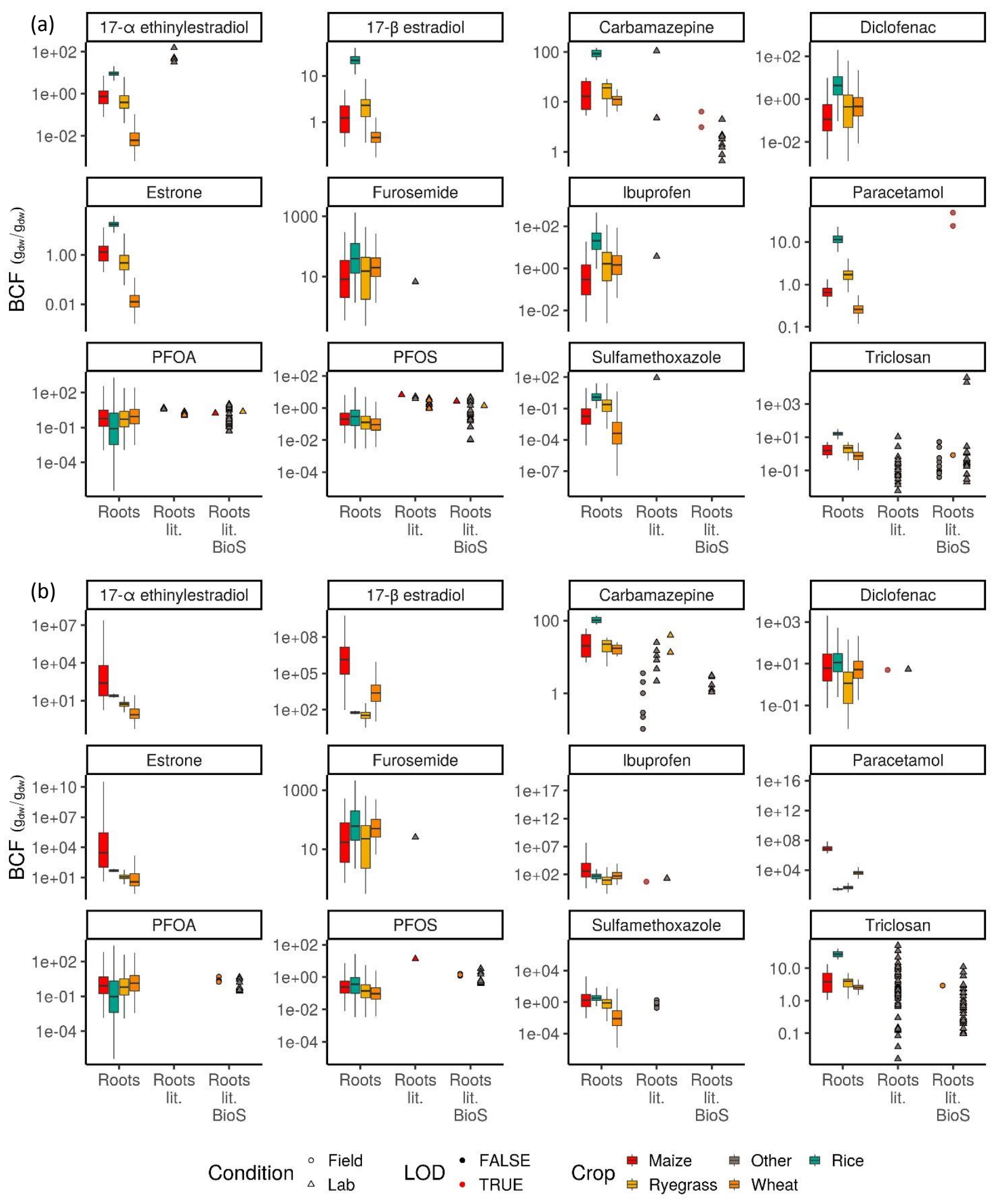

Figure S18. Root BCFs $\left(g_{d w} / g_{d w}\right.$ ) for silage maize, winter wheat, ryegrass and rice with respect to maximum (a) or median (b) soil concentrations and literature (lit.) values. All simulated soils are shown. BioS indicates experimental studies conducted with the use of biosolids. Red borders indicate the use of an LOD value in the calculation of the BCF. References: Aryal and Reinhold (2011), Bizkarguenaga et al. (2016), Blaine et al. (2014), Carter et al. (2014), Fu et al. (2016), Holling et al. (2012), Hurtado et al. (2017), Karnjanapiboonwong et al. (2011), Lechner and Knapp (2011), Macherius et al. (2012), Malchi et al. (2014), Pannu et al. (2012), Prosser et al. (2014), Sabourin et al. (2012), Shenker et al. (2011), Wen et al. (2014, 2016), Winker et al. (2010), Wu et al. (2010, 2012), Yager et al. (2014), Zhao et al. (2014, 2017). 


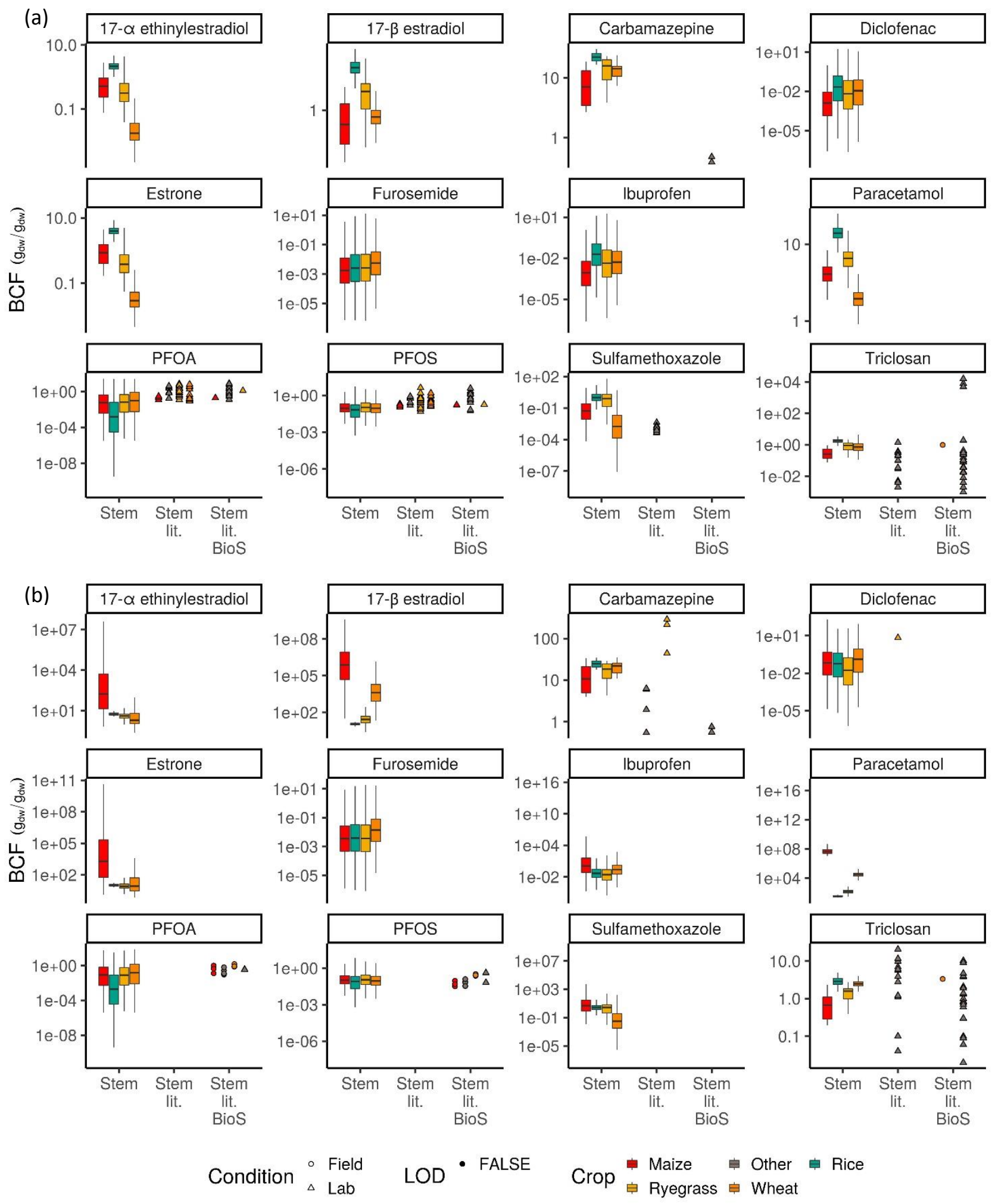

Figure S19. Stem BCFs $\left(\mathrm{g}_{\mathrm{dw}} / \mathrm{g}_{\mathrm{dw}}\right)$ for silage maize, winter wheat, ryegrass and rice with respect to maximum (a) or median (b) soil concentrations and literature (lit.) values. All simulated soils are shown. BioS indicates experimental studies conducted with the use of biosolids. References: Aryal and Reinhold (2011), Blaine et al. (2013, 2014), Carter et al. (2014), Chitescu et al. (2012), Lechner and Knapp (2011), Navarro et al. (2017), Prosser et al. (2014), Shenker et al. (2011), Stahl et al. (2009), Wen et al. (2014, 2016), Winker et al. (2010), Wu et al. (2010), Yager et al. (2014), Yoo et al. (2011), Zhao et al. (2014, 2017). 


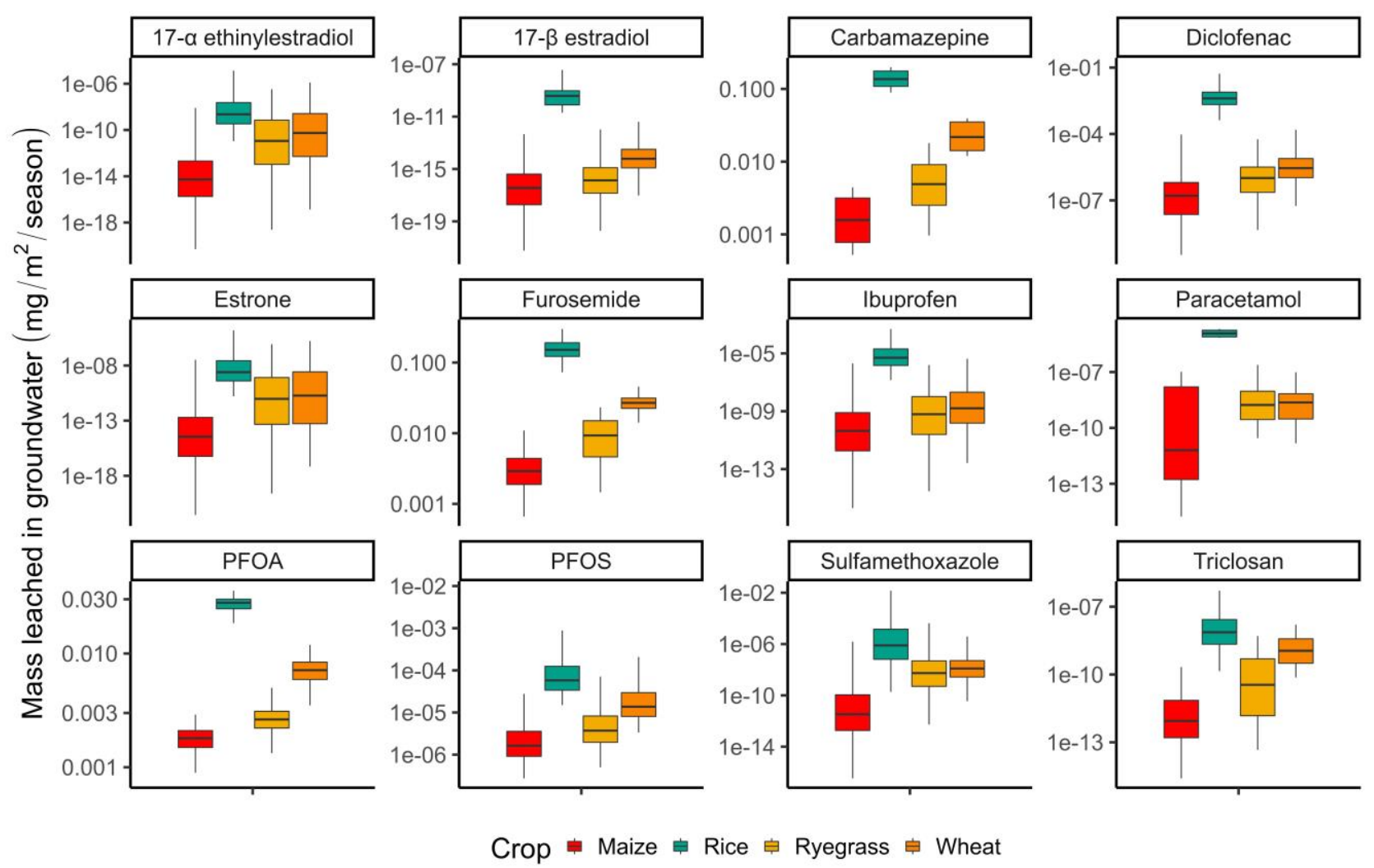

Figure S20. Total leached mass during each crop growing season. 


\section{SI.7 Risk assessment}

\section{SI.7.1 Environmental risk - Results}

Table S22. Maximum, median and minimum RQs at the end of the canal and monthly frequency to exceed a given RQ.

\begin{tabular}{|c|c|c|c|c|c|c|c|c|c|c|c|c|c|}
\hline \multirow{2}{*}{ CEC } & \multirow{2}{*}{$\begin{array}{c}\text { Max/Median/Min } \\
\text { RQ }\end{array}$} & \multicolumn{12}{|c|}{ Monthly frequency of exceedance $(\%)$} \\
\hline & & Jan & Feb & Mar & Apr & May & Jun & Jul & Aug & Sept & Oct & Nov & Dec \\
\hline \multicolumn{14}{|c|}{ RQ above 0.1} \\
\hline \multicolumn{14}{|l|}{ SMX } \\
\hline & $0.42 / 0.16 / 0.018$ & 74.1 & 73.9 & 73.5 & 73.5 & 73.4 & 72.7 & 72.4 & 72.6 & 73.7 & 73.9 & 74.2 & 74.1 \\
\hline \multicolumn{14}{|l|}{ IBU } \\
\hline & $0.15 / 0.07 / 0.021$ & 16.9 & 16.7 & 16.5 & 16.4 & 16.3 & 15.9 & 15.8 & 15.9 & 16.2 & 16.4 & 16.7 & 16.8 \\
\hline \multicolumn{14}{|l|}{ E1 } \\
\hline & $0.25 / 0.14 / 0.046$ & 91.7 & 91.5 & 91.3 & 90.8 & 90.5 & 89.2 & 88.4 & 88.8 & 90.6 & 91.2 & 91.5 & 91.7 \\
\hline \multicolumn{14}{|c|}{ RQ above 1} \\
\hline \multicolumn{14}{|c|}{ CLA } \\
\hline & $2.63 / 1.34 / 0.48$ & 80 & 79.8 & 79.7 & 79.4 & 79 & 78.3 & 77.9 & 78 & 78.9 & 79.3 & 80 & 80.4 \\
\hline \multicolumn{14}{|l|}{ EE2 } \\
\hline & $45.88 / 26.74 / 12.86$ & 100 & 100 & 100 & 100 & 100 & 100 & 100 & 100 & 100 & 100 & 100 & 100 \\
\hline \multicolumn{14}{|l|}{$\mathrm{E} 2$} \\
\hline & $2.57 / 1.48 / 0.65$ & 95.8 & 95.6 & 95.4 & 95.1 & 94.9 & 94.1 & 93.6 & 93.8 & 95 & 95.3 & 95.7 & 95.8 \\
\hline \multicolumn{14}{|l|}{ TCS } \\
\hline & $2.56 / 1.43 / 0.44$ & 77.9 & 77.7 & 77.6 & 77.3 & 77.1 & 76.5 & 76.5 & 76.6 & 77.3 & 77.6 & 77.7 & 77.9 \\
\hline
\end{tabular}




\section{SI.7.2 Human health risk - Methods}

Following the precautionary principle, human health risk was calculated with the assumption of no degradation between harvest and consumption and the complete bioaccessibility and bioavailability of the ingested CECs.

To calculate the ingestion required to exceed the threshold of toxicological concern (TTC), TTC was set equal to 30, 9.1, 1.5 and $0.0025 \mu \mathrm{g} \mathrm{kg}_{\mathrm{bw}}{ }^{-1} \mathrm{~d}^{-1}$, depending on the Cramer classes (I, II and III or genotoxic alerts) which the CEC belongs to (Kroes et al., 2004; Malchi et al., 2014).

Regarding the calculation of the hazard quotient (HQ), the ADI values were either found in Prosser and Sibley (2015) or in the reports produced by EFSA (2008), Environment Protection and Heritage Council of Australia (2008) and EMEA (2000) and, eventually, corrected as reported in Malchi et al. (2015).

\section{SI.7.3 Human health risk - Results}

Table S23. Consumption $(\mathrm{kg} / \mathrm{d})$ required to exceed TTC for crops irrigated with water withdrawn at the end of the canal. P97.5 stands for values calculated with the $97.5^{\text {th }}$ percentile CEC concentration.

\begin{tabular}{lcccccccc}
\hline \multirow{2}{*}{ CEC } & \multicolumn{3}{c}{ Infants } & \multicolumn{2}{c}{ Adults } \\
\cline { 2 - 9 } & \multicolumn{2}{c}{ Rice } & \multicolumn{2}{c}{ Wheat } & \multicolumn{2}{c}{ Rice } & \multicolumn{2}{c}{ Wheat } \\
\hline \multirow{2}{*}{ SMX } & Median & P97.5 & Median & P97.5 & Median & P97.5 & Median & P97.5 \\
DCF & 0.07 & 0.01 & 1.92 & 0.23 & 0.38 & 0.05 & 11.2 & 1.32 \\
IBU & $>100$ & 73.51 & $>100$ & $>100$ & $>100$ & $>100$ & $>100$ & $>100$ \\
PAR & $>100$ & $>100$ & $>100$ & $>100$ & $>100$ & $>100$ & $>100$ & $>100$ \\
CBZ & 3.06 & 2.08 & 72.22 & 44.84 & 17.83 & 12.15 & $>100$ & $>100$ \\
FUR & $>.59$ & 5.77 & 19.03 & 15.06 & 50.12 & 33.65 & $>100$ & 87.84 \\
PFOA & $>100$ & $>100$ & $>100$ & $>100$ & $>100$ & $>100$ & $>100$ & $>100$ \\
PFOS & $>100$ & $>100$ & $>100$ & $>100$ & $>100$ & $>100$ & $>100$ & $>100$ \\
TCS & $>100$ & $>100$ & $>100$ & $>100$ & $>100$ & $>100$ & $>100$ & $>100$ \\
\hline
\end{tabular}


Table S24. HQs and His for crops irrigated with water withdrawn at the end of the canal. P97.5 stands for values calculated with the $97.5^{\text {th }}$ percentile CEC concentration.

\begin{tabular}{|c|c|c|c|c|c|c|}
\hline \multirow{2}{*}{ CEC } & \multicolumn{2}{|c|}{ Rice } & \multicolumn{2}{|c|}{ Wheat } & \multicolumn{2}{|c|}{ Total } \\
\hline & Median & P97.5 & Median & P97.5 & Median & P97.5 \\
\hline \multicolumn{7}{|l|}{ Infants } \\
\hline SMX & $2.94 \mathrm{E}-03$ & $2.03 \mathrm{E}-02$ & $1.86 \mathrm{E}-04$ & $1.58 \mathrm{E}-03$ & $3.12 \mathrm{E}-03$ & $2,19 \mathrm{E}-02$ \\
\hline $\mathrm{DCF}$ & $2.66 \mathrm{E}-06$ & $6.35 \mathrm{E}-04$ & $6.14 \mathrm{E}-08$ & $1.26 \mathrm{E}-05$ & $2.72 \mathrm{E}-06$ & $6.48 \mathrm{E}-04$ \\
\hline IBU & $1.12 \mathrm{E}-09$ & $5.27 \mathrm{E}-07$ & $1.21 \mathrm{E}-10$ & 5.94E-08 & $1.24 \mathrm{E}-09$ & $5.86 \mathrm{E}-07$ \\
\hline PAR & $7.12 \mathrm{E}-07$ & $1.05 \mathrm{E}-06$ & 5.64E-08 & $9.08 \mathrm{E}-08$ & 7.69E-07 & $1.14 \mathrm{E}-06$ \\
\hline CBZ & $2.62 \mathrm{E}-03$ & $3.91 \mathrm{E}-03$ & $2.21 \mathrm{E}-03$ & $2.80 \mathrm{E}-03$ & $4.84 \mathrm{E}-03$ & $6.71 \mathrm{E}-03$ \\
\hline FUR & 5.37E-08 & 8.49E-05 & $1.25 \mathrm{E}-07$ & $9.82 \mathrm{E}-05$ & $1.79 \mathrm{E}-07$ & $1.83 \mathrm{E}-04$ \\
\hline EE2 & $2.77 \mathrm{E}-02$ & $2.57 \mathrm{E}-01$ & $1.95 \mathrm{E}-03$ & $3.85 \mathrm{E}-02$ & $2.97 \mathrm{E}-02$ & $2.95 \mathrm{E}-01$ \\
\hline E2 & $1.07 \mathrm{E}-05$ & $2.53 \mathrm{E}-05$ & 8.72E-07 & $2.02 \mathrm{E}-06$ & $1.15 \mathrm{E}-05$ & $2.73 \mathrm{E}-05$ \\
\hline E1 & $5.23 \mathrm{E}-04$ & $4.82 \mathrm{E}-03$ & $4.06 \mathrm{E}-05$ & $7.80 \mathrm{E}-04$ & $5.63 \mathrm{E}-04$ & $5.60 \mathrm{E}-03$ \\
\hline PFOS & $6.98 \mathrm{E}-06$ & $2.75 \mathrm{E}-04$ & $5.44 \mathrm{E}-06$ & $1.24 \mathrm{E}-04$ & $1.24 \mathrm{E}-05$ & $4.00 \mathrm{E}-04$ \\
\hline PFOA & 2.23E-08 & $1.22 \mathrm{E}-04$ & $1.17 \mathrm{E}-06$ & $2.66 \mathrm{E}-04$ & $1.19 \mathrm{E}-06$ & $3.88 \mathrm{E}-04$ \\
\hline \multirow[t]{2}{*}{ TCS } & 6.19E-09 & $1.79 \mathrm{E}-08$ & $2.57 \mathrm{E}-09$ & $1.04 \mathrm{E}-08$ & $8.76 \mathrm{E}-09$ & $2.83 \mathrm{E}-08$ \\
\hline & & & & Hazard Index & $3.82 \mathrm{E}-02$ & $3.31 \mathrm{E}-01$ \\
\hline \multicolumn{7}{|l|}{ Adults } \\
\hline SMX & 4.45E-04 & $3.08 \mathrm{E}-03$ & 8.88E-05 & 7.52E-04 & $5.34 \mathrm{E}-04$ & $3.83 \mathrm{E}-03$ \\
\hline DCF & $4.03 \mathrm{E}-07$ & $9.63 \mathrm{E}-05$ & 2.93E-08 & $6.03 \mathrm{E}-06$ & 4.33E-07 & $1.02 \mathrm{E}-04$ \\
\hline IBU & $1.70 \mathrm{E}-10$ & 7.99E-08 & 2.93E-08 & $6.03 \mathrm{E}-06$ & $2.27 \mathrm{E}-10$ & $1.80 \mathrm{E}-07$ \\
\hline PAR & $1.08 \mathrm{E}-07$ & $1.59 \mathrm{E}-07$ & 2.69E-08 & $4.33 \mathrm{E}-08$ & $1.35 \mathrm{E}-07$ & $2.20 \mathrm{E}-07$ \\
\hline CBZ & $3.98 \mathrm{E}-04$ & 5.93E-04 & $1.06 \mathrm{E}-03$ & $1.33 \mathrm{E}-03$ & $1.45 \mathrm{E}-03$ & $1.93 \mathrm{E}-03$ \\
\hline FUR & $8.14 \mathrm{E}-09$ & $1.29 \mathrm{E}-05$ & $5.96 \mathrm{E}-08$ & 4.69E-05 & $6.78 \mathrm{E}-08$ & 5.97E-05 \\
\hline EE2 & 4.20E-03 & $3.89 \mathrm{E}-02$ & $9.32 \mathrm{E}-04$ & $1.84 \mathrm{E}-02$ & $5.13 \mathrm{E}-03$ & $5.73 \mathrm{E}-02$ \\
\hline E2 & $1.62 \mathrm{E}-06$ & $3.84 \mathrm{E}-06$ & $4.16 \mathrm{E}-07$ & $9.63 \mathrm{E}-07$ & $2.03 \mathrm{E}-06$ & $4.80 \mathrm{E}-06$ \\
\hline E1 & $7.93 \mathrm{E}-05$ & $7.30 \mathrm{E}-04$ & $1.94 \mathrm{E}-05$ & $3.72 \mathrm{E}-04$ & $9.86 \mathrm{E}-05$ & $1.10 \mathrm{E}-03$ \\
\hline PFOS & $1.06 \mathrm{E}-06$ & $1.31 \mathrm{E}-04$ & $2.60 \mathrm{E}-06$ & 5.94E-05 & $3.65 \mathrm{E}-06$ & $1.90 \mathrm{E}-04$ \\
\hline PFOA & 3.38E-09 & $1.85 \mathrm{E}-05$ & $5.58 \mathrm{E}-07$ & $1.27 \mathrm{E}-04$ & $5.62 \mathrm{E}-07$ & $1.46 \mathrm{E}-04$ \\
\hline \multirow[t]{2}{*}{ TCS } & $9.38 \mathrm{E}-10$ & 2.71E-09 & $1.23 \mathrm{E}-09$ & $4.96 \mathrm{E}-09$ & $2.17 \mathrm{E}-09$ & 7.67E-09 \\
\hline & & & & Hazard Index & $7.22 \mathrm{E}-03$ & $6.47 \mathrm{E}-02$ \\
\hline
\end{tabular}




\section{SI.8 References}

Abraha, M. G., Savage, M. J. (2008). The soil water balance of rainfed and irrigated oats, Italian rye grass and rye using the CropSyst model. Irrigation Science, 26(3), 203-212.

Acuña, V., von Schiller, D., García-Galán, M. J., Rodríguez-Mozaz, S., Corominas, L., Petrovic, M., ... Sabater, S. (2015). Occurrence and in-stream attenuation of wastewater-derived pharmaceuticals in Iberian rivers. Science of the Total Environment, 503-504, 133-141.

Adamek, E., Baran, W., Sobczak, A. (2016). Assessment of the biodegradability of selected sulfa drugs in two polluted rivers in Poland: Effects of seasonal variations, accidental contamination, turbidity and salinity. Journal of Hazardous Materials, 313, 147-158.

Ahrens, L., Harner, T., Shoeib, M., Lane, D. A., Murphy, J. G. (2012). Improved characterization of gasparticle partitioning for per- and polyfluoroalkyl substances in the atmosphere using annular diffusion denuder samplers. Environmental Science and Technology, 46(13), 7199-7206.

Al-Ahmad, A., Daschner, F. D., Kümmerer, K. (1999). Biodegradability of cefotiam, ciprofloxacin, meropenem, penicillin $\mathrm{G}$, and sulfamethoxazole and inhibition of waste water bacteria. Archives of Environmental Contamination and Toxicology, 37(2), 158-163.

Alexy, R., Kümpel, T., Kümmerer, K. (2004). Assessment of degradation of 18 antibiotics in the Closed Bottle Test. Chemosphere, 57(6), 505-512.

Allen, R., Pereira, L. S., Raes, D., Smith, M. (1998). Crop Evapotranspiration - Guidelines for computing crop water requirements - FAO Irrigation and Drainage paper. Rome, Italy.

Andreozzi, R., Marotta, R., Paxéus, N. (2003). Pharmaceuticals in STP effluents and their solar photodegradation in aquatic environment. Chemosphere, 50(10), 1319-1330.

Arp, H. P. H., Niederer, C., Goss, K. (2006). Predicting the Partitioning Behavior of Various Highly Fluorinated. Environmental Science and Technology, 40(23), 7298-7304.

Aryal, N., Reinhold, D. M. (2011). Phytoaccumulation of antimicrobials from biosolids : Impacts on environmental fate and relevance to human exposure. Water Research, 45(17), 5545-5552.

Atkinson, S. K., Marlatt, V. L., Kimpe, L. E., Lean, D. R. S., Trudeau, V. L., Blais, J. M. (2011). Environmental factors affecting ultraviolet photodegradation rates and estrogenicity of estrone and ethinylestradiol in natural waters. Archives of Environmental Contamination and Toxicology, 60(1), 1-7. 
Baena-Nogueras, R. M., González-Mazo, E., Lara-Martín, P. A. (2017). Degradation kinetics of pharmaceuticals and personal care products in surface waters: photolysis vs biodegradation. Science of the Total Environment, 590-591, 643-654.

Bahnmüller, S., von Gunten, U., Canonica, S. (2014). Sunlight-induced transformation of sulfadiazine and sulfamethoxazole in surface waters and wastewater effluents. Water Research, 57, 183-192.

Barron, L., Havel, J., Purcell, M., Szpak, M., Kelleher, B., Paull, B. (2009). Predicting sorption of pharmaceuticals and personal care products onto soil and digested sludge using artificial neural networks. Analyst, 134(4), 663-670.

Beesoon, S., Martin, J. W. (2015). Isomer-Specific Binding Affinity of Perfluorooctanesulfonate (PFOS) and Perfluorooctanoate (PFOA) to Serum Proteins. Environmental Science \& Technology, 49(9), 5722-5731.

Ben Mordechay, E., Tarchitzky, J., Chen, Y., Shenker, M., Chefetz, B. (2018). Composted biosolids and treated wastewater as sources of pharmaceuticals and personal care products for plant uptake: A case study with carbamazepine. Environmental Pollution, 232, 164-172.

Bester, K. (2005). Fate of triclosan and triclosan-methyl in sewage treatment plants and surface waters. Archives of Environmental Contamination and Toxicology, 49(1), 9-17.

Bhhatarai, B., Gramatica, P. (2011). Prediction of Aqueous Solubility, Vapor Pressure and Critical Micelle Concentration for Aquatic Partitioning of Perfluorinated Chemicals. Environmental Science \& Technology, 45(19), 8120-8128.

Bischel, H. N., MacManus-Spencer, L. A., Luthy, R. G. (2010). Noncovalent Interactions of Long-Chain Perfluoroalkyl Acids with Serum Albumin. Environmental Science \& Technology, 44(13), 5263-5269.

Bizkarguenaga, E., Zabaleta, I., Mijangos, L., Iparraguirre, A., Fernández, L. A., Prieto, A., Zuloaga, O. (2016). Uptake of perfluorooctanoic acid, perfluorooctane sulfonate and perfluorooctane sulfonamide by carrot and lettuce from compost amended soil. Science of the Total Environment, 571, 444-451.

Blaine, A. C., Rich, C. D., Hundal, L. S., Lau, C., Mills, M. A., Harris, K. M., Higgins, C. P. (2013). Uptake of perfluoroalkyl acids into edible crops via land applied biosolids: Field and greenhouse studies. Environmental Science and Technology, 47(24), 14062-14069. 
Blaine, A. C., Rich, C. D., Sedlacko, E. M., Hundal, L. S., Kumar, K., Lau, C., ... Higgins, C. P. (2014). Perfluoroalkyl acid distribution in various plant compartments of edible crops grown in biosolidsamended soils. Environmental Science and Technology, 48(14), 7858-7865.

Bonvin, F., Omlin, J., Rutler, R., Schweizer, W. B., Alaimo, P. J., Strathmann, T. J., ... Kohn, T. (2013). Direct photolysis of human metabolites of the antibiotic sulfamethoxazole: Evidence for abiotic backtransformation. Environmental Science and Technology, 47(13), 6746-6755.

Boreen, A. L., Arnold, W. A., McNeill, K. (2004). Photochemical fate of sulfa drugs in then aquatic environment: Sulfa drugs containing five-membered heterocyclic groups. Environmental Science and Technology, 38(14), 3933-3940.

Borrelli, L., Castelli, F., Ceotto, E., Cabassi, G., Tomasoni, C. (2014). Maize grain and silage yield and yield stability in a long-term cropping system experiment in northern italy. European Journal of Agronomy, 55, $12-19$.

Brace, N. O. (1962). Long Chain Alkanoic and Alkenoic Acids with Perfluoroalkyl Terminal Segments. Journal of Organic Chemistry, 27(12), 4491-4498.

Bradley, P. M., Barber, L. B., Chapelle, F. H., Gray, J. L., Kolpin, D. W., McMahon, P. B. (2009). Biodegradation of 17beta-estradiol, estrone and testosterone in stream sediments. Environmental Science \& Technology, 43(6), 1902-1910.

Brenna, S., Rocca, A., Sciaccaluga, Ma., Valagussa, M. (2010). SOILQUALIMON - Sistema di monitoraggio della qualità dei suoli in Lombardia. In Quaderni della Ricerca (Vol. 110).

Brooke, D., Footitt, A., Nwaogu, T. A. (2004). Environmental Risk Evaluation Report: Perfluorooctanesulphonate (PFOS). In Environment Agency.

Burns, D. C., Ellis, D. A., Webster, E., McMurdo, C. J. (2009). Response to Comment on "Experimental p K a Determination for Perfluorooctanoic Acid (PFOA) and the Potential Impact of $\mathrm{p} \mathrm{K}$ a Concentration Dependence on Laboratory-Measured Partitioning Phenomena and Environmental Modeling." Environmental Science \& Technology, 43(13), 5152-5154.

Buser, H. R., Poiger, T., Muller, M. D. (1999). Occurrence and environmental behavior of the chiral pharmaceutical drug ibuprofen in surface waters and in wastewater. Environmental Science and Technology, 33(15), 2529-2535. 
Buser, H. R., Poiger, T., Müller, M. D. (1998). Occurrence and fate of the pharmaceutical drug diclofenac in surface waters: Rapid photodegradation in a lake. Environmental Science and Technology, 32(22), 34493456.

Caldwell, D. J., Mastrocco, F., Anderson, P. D., Länge, R., Sumpter, J. P. (2012). Predicted-no-effect

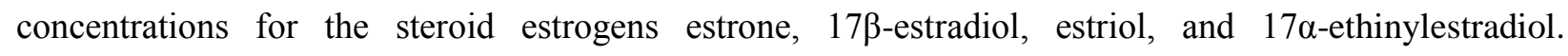
Environmental Toxicology and Chemistry, 31(6), 1396-1406.

Calza, P., Medana, C., Padovano, E., Giancotti, V., Minero, C. (2013). Fate of selected pharmaceuticals in river waters. Environmental Science and Pollution Research, 20(4), 2262-2270.

Carlos, L., Mártire, D. O., Gonzalez, M. C., Gomis, J., Bernabeu, A., Amat, A. M., Arques, A. (2012). Photochemical fate of a mixture of emerging pollutants in the presence of humic substances. Water Research, 46(15), 4732-4740.

Carr, D. L., Morse, A. N., Zak, J. C., Anderson, T. A. (2011). Biological degradation of common pharmaceuticals and personal care products in soils with high water content. Water, Air, and Soil Pollution, 217(1-4), 127-134.

Carter, L. J., Harris, E., Williams, M., Ryan, J. J., Kookana, R. S., Boxall, A. B. A. (2014). Fate and Uptake of Pharmaceuticals in Soil-Plant Systems. Journal of Agricultural and Food Chemistry, 62(4), 816-825.

Castiglioni, S., Davoli, E., Riva, F., Palmiotto, M., Camporini, P., Manenti, A., Zuccato, E. (2018a). Data on occurrence and fate of emerging contaminants in a urbanised area. Data in Brief, 17, 533-543.

Castiglioni, S., Davoli, E., Riva, F., Palmiotto, M., Camporini, P., Manenti, A., Zuccato, E. (2018b). Mass balance of emerging contaminants in the water cycle of a highly urbanized and industrialized area of Italy. Water Research, 131, 287-298.

Caupos, E., Mazellier, P., Croue, J. P. (2011). Photodegradation of estrone enhanced by dissolved organic matter under simulated sunlight. Water Research, 45(11), 3341-3350.

Challis, J. K., Hanson, M. L., Friesen, K. J., Wong, C. S. (2014). A critical assessment of the photodegradation of pharmaceuticals in aquatic environments: defining our current understanding and identifying knowledge gaps. Environmental Science: Processes \& Impacts, 16(4), 672-696.

Chapra, S. C. (1997). Surface Water-Quality Modeling. In McGraw-Hill Series in Water Resources and Environmental Engineering. 
Chen, Y. M., Guo, L. H. (2009). Fluorescence study on site-specific binding of perfluoroalkyl acids to human serum albumin. Archives of Toxicology, 83(3), 255-261.

Chitescu, C. L., Nicolau, A. I., Stolker, A. A. M. (2013). Uptake of oxytetracycline, sulfamethoxazole and ketoconazole from fertilised soils by plants. Food Additives and Contaminants - Part A Chemistry, Analysis, Control, Exposure and Risk Assessment, 30(6), 1138-1146.

Chowdhury, R. R., Charpentier, P. A., Ray, M. B. (2011). Photodegradation of $17 \beta$-estradiol in aquatic solution under solar irradiation: Kinetics and influencing water parameters. Journal of Photochemistry and Photobiology A: Chemistry, 219(1), 67-75.

Chowdhury, R. R., Charpentier, P., Ray, M. B. (2010). Photodegradation of estrone in solar irradiation. Industrial and Engineering Chemistry Research, 49(15), 6923-6930.

Christou, A., Karaolia, P., Hapeshi, E., Michael, C., Fatta-Kassinos, D. (2017). Long-term wastewater irrigation of vegetables in real agricultural systems: Concentration of pharmaceuticals in soil, uptake and bioaccumulation in tomato fruits and human health risk assessment. Water Research, 109(1-2), 24-34.

Colucci, M. S., Bork, H., Topp, E. (2001). Persistence of estrogenic hormones in agricultural soils: I. 17Betaestradiol and estrone. J Environ Qual, 30(6), 2070-2076.

Colucci, M. S., Topp, E. (2002). Dissipation of part per trillion concentrations of estrogenic hormones from agricultural soils. Canadian Journal of Soil Science, 82(3), 335-340.

Colucci, M. S., Topp, E. (2001). Persistence of Estrogenic Hormones in Agricultural Soils: II. 17alphaEthynylestradiol. Journal of Environment Quality, 30(6), 2077-2080.

Confalonieri, R., Bocchi, S. (2005). Evaluation of CropSyst for simulating the yield of flooded rice in northern Italy. European Journal of Agronomy, 23(4), 315-326.

Conkle, J. L., Gan, J., Anderson, M. A. (2012). Degradation and sorption of commonly detected PPCPs in wetland sediments under aerobic and anaerobic conditions. Journal of Soils and Sediments, 12(7), 11641173.

Czajka, C. P., Londry, K. L. (2006). Anaerobic biotransformation of estrogens. Science of the Total Environment, 367(2-3), 932-941. 
De Laurentiis, E., Chiron, S., Kouras-Hadef, S., Richard, C., Minella, M., Maurino, V., ... Vione, D. (2012). Photochemical fate of carbamazepine in surface freshwaters: Laboratory measures and modeling. Environmental Science and Technology, 46(15), 8164-8173.

De Laurentiis, E., Prasse, C., Ternes, T. A., Minella, M., Maurino, V., Minero, C., ... Vione, D. (2014). Assessing the photochemical transformation pathways of acetaminophen relevant to surface waters: Transformation kinetics, intermediates, and modelling. Water Research, 53, 235-248.

de Mes, T., Zeeman, G., Lettinga, G. (2005). Occurrence and fate of estrone, 17 $\beta$-estradiol and 17 $\alpha$ ethynylestradiol in STPs for domestic wastewater. Reviews in Environmental Science and Bio/Technology, (4), 275-311.

Ding, G., Peijnenburg, W. J. G. M. (2013). Physicochemical Properties and Aquatic Toxicity of Poly- and Perfluorinated Compounds. Critical Reviews in Environmental Science and Technology, 43(6), 598-678.

Doll, T. E., Frimmel, F. H. (2003). Fate of pharmaceuticals - Photodegradation by simulated solar UV-light. Chemosphere, 52(10), 1757-1769.

Dong, M. M., Trenholm, R., Rosario-Ortiz, F. L. (2015). Photochemical degradation of atenolol, carbamazepine, meprobamate, phenytoin and primidone in wastewater effluents. Journal of Hazardous Materials, 282, 216-223.

Durán-Álvarez, J. C., Prado, B., González, D., Sánchez, Y., Jiménez-Cisneros, B. (2015). Environmental fate of naproxen, carbamazepine and triclosan in wastewater, surface water and wastewater irrigated soil Results of laboratory scale experiments. Science of the Total Environment, 538, 350-362.

ECHA. (2006). Paracetamol - Environmental fate \& pathways. Retrieved December 18, 2018, from https://echa.europa.eu/registration-dossier/-/registered-dossier/12532/5/5/2

EFSA. (2008). Perfluorooctane sulfonate (PFOS), perfluorooctanoic acid (PFOA) and their salts. The EFSA Journal, 653, 1-131.

EFSA. (2007). Opinion on a request from EFSA related to the default Q10 value used to describe the temperature effect on transformation rates of pesticides in soil. The EFSA Journal, 622, 1-32.

EMEA Committee for Veterinary Medicinal Products (2000). Furosemide - Summary Report. Technical Report September 1999. 
Environment Protection and Heritage Council of Australia (2008). Australian Guidelines for Water Recycling: Managing Health and Environmental Risks (Phase 2) - Augmentation of Drinking Water Supplies. Technical Report 22.

European Commission Joint Research Centre. (2003). Technical guidance document on risk assessment in support of Commission Directive 93/67/ EEC on risk assessment for new notified substances and Commission Regulation (EC) No. 1488/94 on risk assessment for existing substances. Part II. EUR 20418 EN/2. European Chemicals Bureau, Part II, 7-179.

Falås, P., Longrée, P., La Cour Jansen, J., Siegrist, H., Hollender, J., Joss, A. (2013). Micropollutant removal by attached and suspended growth in a hybrid biofilm-activated sludge process. Water Research, 47(13), $4498-4506$.

FAO (2007). ECOCROP - Data Sheet - Lolium multiflorum. URL: http://ecocrop.fao.org/ecocrop/srv/en/dataSheet?id=7389. Last accessed: 05-10-2018.

Felle, H. H., Herrmann, A., Hückelhoven, R., Kogel, K. H. (2005). Root-to-shoot signalling: Apoplastic alkalinization, a general stress response and defence factor in barley (Hordeum vulgare). Protoplasma, 227(1), 17-24.

Felle, H. H. (2001). pH: Signal and messenger in plant cells. Plant Biology, 3(6), 577-591.

Fenner, K., Honti, M., Stamm, C., Varga, L., Bischoff, F. (2016). Suitability of laboratory simulation tests for the identification of persistence in surface waters.

Fono, L. J., Kolodziej, E. P., Sedlak, D. L. (2006). Attenuation of wastewater-derived contaminants in an effluent-dominated river. Environmental Science and Technology, 40(23), 7257-7262.

Franco, A., Ferranti, A., Davidsen, C., Trapp, S. (2010). An unexpected challenge: Ionizable compounds in the REACH chemical space. International Journal of Life Cycle Assessment, 15(4), 321-325.

Franco, A., Struijs, J., Gouin, T., Price, O. R. (2013). Evolution of the sewage treatment plant model SimpleTreat: Applicability domain and data requirements. Integrated Environmental Assessment and Management, 9(4), 560-568.

Franco, A., Trapp, S. (2008). Estimation of the soil-water partitioning coefficient normalized to organic carbon for ionizable organic chemicals. Environmental Toxicology and Chemistry, 27(10), 1995-2004. 
Franco, A., Trapp, S. (2010). A multimedia activity model for ionizable compounds: Validation study with 2,4-dichlorophenoxyacetic acid, aniline, and trimethoprim. Environmental Toxicology and Chemistry, 29(4), 789-799.

Fu, Q., Wu, X., Ye, Q., Ernst, F., Gan, J. (2016). Biosolids inhibit bioavailability and plant uptake of triclosan and triclocarban. Water Research, 102, 117-124.

Giesy, J. P., Naile, J. E., Khim, J. S., Jones, P. D., Newsted, J. L. (2010). Aquatic Toxicology of Perfluorinated Chemicals. In D. M. Whitacre (Ed.), Reviews of Environmental Contamination and Toxicology (Vol. 202).

Goldstein, M., Shenker, M., Chefetz, B. (2014). Insights into the Uptake Processes of Wastewater-Borne Pharmaceuticals by Vegetables. Environmental Science \& Technology, 48, 5593-5600.

Goss, K. U. (2008). The pKa values of PFOA and other highly fluorinated carboxylic acids. Environmental Science and Technology, 42(2), 456-458.

Gozlan, I., Koren, I. (2016). Identification, Mechanisms and Kinetics of Macrolide Degradation Product Formation under Controlled Environmental Conditions. Journal of Environmental Analytical Chemistry, 03(01), 1-9.

Gredelj, A., Barausse, A., Grechi, L., Palmeri, L. (2018). Deriving predicted no-effect concentrations (PNECs) for emerging contaminants in the river Po, Italy, using three approaches: Assessment factor, species sensitivity distribution and AQUATOX ecosystem modelling. Environment International, 119(June), 66-78.

Gröning, J., Held, C., Garten, C., Claußnitzer, U., Kaschabek, S. R., Schlömann, M. (2007). Transformation of diclofenac by the indigenous microflora of river sediments and identification of a major intermediate. Chemosphere, 69(4), 509-516.

Grossberger, A., Hadar, Y., Borch, T., Chefetz, B. (2014). Biodegradability of pharmaceutical compounds in agricultural soils irrigated with treated wastewater. Environmental Pollution, 185, 168-177.

Grzybowski, W., Szydłowski, J. (2014). The impact of chromophoric dissolved organic matter on the photodegradation of 17 $\alpha$-ethinylestradiol (EE2) in natural waters. Chemosphere, 111, 13-17. 
Guillet, G., Knapp, J. L. A., Merel, S., Cirpka, O. A., Grathwohl, P., Zwiener, C., Schwientek, M. (2019). Fate of wastewater contaminants in rivers: Using conservative-tracer based transfer functions to assess reactive transport. Science of The Total Environment, 656, 1250-1260.

Han, X., Snow, T. A., Kemper, R. A., Jepson, G. W. (2003). Binding of perfluorooctanoic acid to rat and human plasma proteins. Chemical Research in Toxicology, 16(6), 775-781.

Hanamoto, S., Nakada, N., Yamashita, N., Tanaka, H. (2013). Modeling the photochemical attenuation of down-the-drain chemicals during river transport by stochastic methods and field measurements of pharmaceuticals and personal care products. Environmental Science and Technology, 47(23), 1357113577.

Hebert, P. C., MacManus-Spencer, L. A. (2010). Development of a Fluorescence Model for the Binding of Medium- to Long-Chain Perfluoroalkyl Acids to Human Serum Albumin Through a Mechanistic Evaluation of Spectroscopic Evidence. Analytical Chemistry, 82(15), 6463-6471.

Henry, A., Cal, A. J., Batoto, T. C., Torres, R. O., Serraj, R. (2012). Root attributes affecting water uptake of rice (Oryza sativa) under drought. Journal of Experimental Botany, 63(13), 4751-4763.

Henze, M., Gujer, W., Mino, T., Loosdrecht, M. van. (2002). Activated Sludge Models ASM1, ASM2, ASM2d and ASM3. In IWA Task Group on Mathematical Modelling for Design and Operation of Biological Wastewater Treatment. IWA Publishing.

Higgins, C. P., Luthy, R. G. (2006). Sorption of perfluorinated surfactants on sediments. Environmental Science and Technology, 40(23), 7251-7256.

Holling, C. S., Bailey, J. L., Heuvel, V., Kinney, C. A. (2012). Uptake of human pharmaceuticals and personal care products by cabbage (Brassica campestris) from fortified and biosolids-amended soils. Journal of Environmental Monitoring, 14, 3029-3036.

Huang, Q., Bu, Q., Zhong, W., Shi, K., Cao, Z., Yu, G. (2018). Derivation of aquatic predicted no-effect concentration (PNEC) for ibuprofen and sulfamethoxazole based on various toxicity endpoints and the associated risks. Chemosphere, 193, 223-229.

Hurtado, C., Cañameras, N., Domínguez, C., Price, G. W., Comas, J., Bayona, J. M. (2017). Effect of soil biochar concentration on the mitigation of emerging organic contaminant uptake in lettuce. Journal of Hazardous Materials, 323(April 2016), 386-393. 
Igarashi, S., Yotsuyanagi, T. (1992). Homogeneous liquid-liquid extraction by $\mathrm{pH}$ dependent phase separation with a fluorocarbon ionic surfactant and its application to the preconcentration of porphyrin compounds. Mikrochimica Acta, 106(1-2), 37-44.

Jakimska, A., Śliwka-Kaszyńska, M., Reszczyńska, J., Namieśnik, J., Kot-Wasik, A. (2014). Elucidation of transformation pathway of ketoprofen, ibuprofen, and furosemide in surface water and their occurrence in the aqueous environment using UHPLC-QTOF-MS Euroanalysis XVII. Analytical and Bioanalytical Chemistry, 406(15), 3667-3680.

Jensen, A. A., Poulsen, P. B., Bossi, R. (2008). Survey and environmental/health assessment of fluorinated substances in impregnated consumer products and impregnating agents. In Survey of Chemical Substances in Consumer Products.

Jing, P., Rodgers, P. J., Amemiya, S. (2009). High lipophilicity of perfluoroalkyl carboxylate and sulfonate: Implications for their membrane permeability. Journal of the American Chemical Society, 131(6), 22902296.

Johannes, E., Collings, D. a, Rink, J. C., Allen, N. S. (2001). Cytoplasmic pH dynamics in maize pulvinal cells induced by gravity vector changes. Plant Physiology, 127(1), 119-130.

Jurgens, M. D., Holthaus, K. I. E., Johnson, A. C., Smith, J. J. L., Hetheridge, M., Williams, R. J. (2002). The potential for estradiol and ethyinylestradiol degradation in English Rivers. Environmental Toxicology and Chemistry, 21(3), 480-488.

Karnjanapiboonwong, A., Chase, D. A., Cañas, J. E., Jackson, W. A., Maul, J. D., Morse, A. N., Anderson, T. A. (2011). Uptake of 17a-ethynylestradiol and triclosan in pinto bean, Phaseolus vulgaris. Ecotoxicology and Environmental Safety, 74(5), 1336-1342.

Kawabata, K., Sugihara, K., Sanoh, S., Kitamura, S., Ohta, S. (2013). Photodegradation of pharmaceuticals in the aquatic environment by sunlight and UV-A, -B and -C irradiation. The Journal of Toxicological Sciences, 38(2), 215-223.

Khan, S. J., Ongerth, J. E. (2004). Modelling of pharmaceutical residues in Australian sewage by quantities of use and fugacity calculations. Chemosphere, 54(3), 355-367.

Kleier, D. A., Hsu, F. C. (1996). Phloem Mobility of Xenobiotics. VII. The Design of Phloem Systemic Pesticides. Weed Science, 44(3), 749-756. 
Kodešová, R., Kočárek, M., Klement, A., Golovko, O., Koba, O., Fér, M., ... Grabic, R. (2016). An analysis of the dissipation of pharmaceuticals under thirteen different soil conditions. Science of the Total Environment, 544, 369-381.

Koumaki, E., Mamais, D., Noutsopoulos, C. (2018). Assessment of the environmental fate of endocrine disrupting chemicals in rivers. Science of the Total Environment, 628-629, 947-958.

Koumaki, E., Mamais, D., Noutsopoulos, C. (2017). Environmental fate of non-steroidal anti-inflammatory drugs in river water/sediment systems. Journal of Hazardous Materials, 323, 233-241.

Koumaki, E., Mamais, D., Noutsopoulos, C., Nika, M. C., Bletsou, A. A., Thomaidis, N. S., ... Stratogianni, G. (2015). Degradation of emerging contaminants from water under natural sunlight: The effect of season, $\mathrm{pH}$, humic acids and nitrate and identification of photodegradation by-products. Chemosphere, $138,675-681$.

Kroes, R., Renwick, A., Cheeseman, M., Kleiner, J., Mangelsdorf, I., Piersma, A., Schilter, B., Schlatter, J., van Schothorst, F., Vos, J., and Würtzen, G. (2004). Structure-based thresholds of toxicological concern (TTC): guidance for application to substances present at low levels in the diet. Food and Chemical Toxicology, 42(1):65-83.

Kunkel, U., Radke, M. (2008). Biodegradation of Acidic Pharmaceuticals in Bed Sediments : Insight from a Laboratory Experiment. Environmental Science and Technology, 42(19), 7273-7279.

Kunkel, U., Radke, M. (2011). Reactive tracer test to evaluate the fate of pharmaceuticals in rivers. Environmental Science and Technology, 45(15), 6296-6302.

Lai, H. T., Hou, J. H. (2008). Light and microbial effects on the transformation of four sulfonamides in eel pond water and sediment. Aquaculture, 283(1-4), 50-55.

Lam, M. W., Mabury, S. A. (2005). Photodegradation of the pharmaceuticals atorvastatin, carbamazepine, levofloxacin, and sulfamethoxazole in natural waters. Aquatic Sciences, 67(2), 177-188.

Lam, M. W., Young, C. J., Brain, R. A., Johnson, D. J., Hanson, M. A., Wilson, C. J., ... Mabury, S. A. (2004). Aquatic persistance of eight pharmaceuticals in a microcosm study. Environmental Toxicology and Chemistry, 23(6), 1431-1440. 
Latch, D. E., Packer, J. L., Stender, B. L., VanOverbeke, J., Arnold, W. A., McNeill, K. (2005). Aqueous photochemistry of triclosan: Formation of 2,4-dichlorophenol, 2,8-dichlorodibenzo-p-dioxin, and oligomerization products. Environmental Toxicology and Chemistry, 24(3), 517-525.

Lechner, M., Knapp, H. (2011). Carryover of Perfluorooctanoic Acid (PFOA) and Perfluorooctane Sulfonate (PFOS) from Soil to Plant and Distribution to the Different Plant Compartments Studied in Cultures of Carrots (Daucus carota ssp. Sativus), Potatoes (Solanum tuberosum), and Cucu. Journal of Agricultural and Food Chemistry, 59(20), 11011-11018.

Leech, D. M., Snyder, M. T., Wetzel, R. G. (2009). Natural organic matter and sunlight accelerate the degradation of 17ß-estradiol in water. Science of the Total Environment, 407(6), 2087-2092.

Legind, C. N., Rein, A., Serre, J., Brochier, V., Haudin, C. S., Cambier, P., ... Trapp, S. (2012). Simultaneous Simulations of Uptake in Plants and Leaching to Groundwater of Cadmium and Lead for Arable Land Amended with Compost or Farmyard Manure. PLoS ONE, 7(10), 1-13.

Li, F. H., Yao, K., Lv, W. Y., Liu, G. G., Chen, P., Huang, H. P., Kang, Y. P. (2015). Photodegradation of ibuprofen under UV-VIS irradiation: Mechanism and toxicity of photolysis products. Bulletin of Environmental Contamination and Toxicology, 94(4), 479-483.

Li, J., Zhang, Y., Huang, Q., Shi, H., Yang, Y., Gao, S., ... Yang, X. (2017). Degradation of organic pollutants mediated by extracellular peroxidase in simulated sunlit humic waters: A case study with 17Bestradiol. Journal of Hazardous Materials, 331, 123-131.

Li, J., Dodgen, L., Ye, Q., Gan, J. (2013). Degradation kinetics and metabolites of carbamazepine in soil. Environmental Science and Technology, 47(8), 3678-3684.

Li, J., Ye, Q., Gan, J. (2014). Degradation and transformation products of acetaminophen in soil. Water Research, 49, 44-52.

Li, J., Ye, Q., Gan, J. (2015). Influence of organic amendment on fate of acetaminophen and sulfamethoxazole in soil. Environmental Pollution, 206, 543-550.

Li, L., Xu, Z. S., Song, G. W. (2009). Study on the Langmuir aggregation of fluorinated surfactants on protein. Journal of Fluorine Chemistry, 130(2), 225-230.

Li, Y., Pan, Y., Lian, L., Yan, S., Song, W., Yang, X. (2017). Photosensitized degradation of acetaminophen in natural organic matter solutions: The role of triplet states and oxygen. Water Research, 109, 266-273. 
Li, Z., Sobek, A., Radke, M. (2015). Flume experiments to investigate the environmental fate of pharmaceuticals and their transformation products in streams. Environmental Science and Technology, 49(10), 6009-6017.

Lin, A. Y. C., Plumlee, M. H., Reinhard, M. (2006). Natural attenuation of pharmaceuticals and alkylphenol polyethoxylate metabolites during river transport: Photochemical and biological transformation. Environmental Toxicology and Chemistry, 25(6), 1458-1464.

Lin, A. Y. C., Reinhard, M. (2005). Photodegradation of common environmental pharmaceuticals and estrogens in river water. Environmental Toxicology and Chemistry, 24(6), 1303-1309.

Lin, A. Y. C., Lin, C. A., Tung, H. H., Chary, N. S. (2010). Potential for biodegradation and sorption of acetaminophen, caffeine, propranolol and acebutolol in lab-scale aqueous environments. Journal of Hazardous Materials, 183(1-3), 242-250.

Lin, K., Gan, J. (2011). Sorption and degradation of wastewater-associated non-steroidal anti-inflammatory drugs and antibiotics in soils. Chemosphere, 83(3), 240-246.

Lindström, A., Buerge, I. J., Poiger, T., Bergqvist, P. A., Müller, M. D., Buser, H. R. (2002). Occurrence and environmental behavior of the bactericide triclosan and its methyl derivative in surface waters and in wastewater. Environmental Science and Technology, 36(11), 2322-2329.

Liou, J. S. C., Szostek, B., DeRito, C. M., Madsen, E. L. (2010). Investigating the biodegradability of perfluorooctanoic acid. Chemosphere, 80(2), 176-183.

Liu, F., Ying, G.-G., Yang, J.-F., Zhou, L.-J., Tao, R., Wang, L., ... Peng, P.-A. (2010). Dissipation of sulfamethoxazole, trimethoprim and tylosin in a soil under aerobic and anoxic conditions. Environmental Chemistry, 7(4), 370-376.

Liu, Y., Sun, W., Ni, J. (2011). Biodegradation of bisphenol A, 17 $\beta$-estradiol, and 17 $\alpha$-ethynylestradiol in river water. International Journal of Environment and Pollution, 45, 225-236.

Liu, Y., Sun, H., Zhang, L., Feng, L. (2017). Photodegradation behaviors of $17 \beta$-estradiol in different water matrixes. Process Safety and Environmental Protection, 112, 335-341.

Löffler, D., Römbke, J., Meller, M., Ternes, T. A. (2005). Environmental fate of pharmaceuticals in water/sediment systems. Environmental Science and Technology, 39(14), 5209-5218. 
López-Fontán, J. L., Sarmiento, F., Schulz, P. C. (2005). The aggregation of sodium perfluorooctanoate in water. Colloid and Polymer Science, 283(8), 862-871.

Macherius, A., Eggen, T., Lorenz, W. G., Reemtsma, T., Winkler, U., Moeder, M. (2012). Uptake of Galaxolide, Tonalide, and Triclosan by Carrot, Barley, and Meadow Fescue Plants. Journal of Agricultural and Food Chemistry, 60(32), 7785-7791.

Malchi, T., Maor, Y., and Chefetz, B. (2015). Comments on "Human health risk assessment of pharmaceuticals and personal care products in plant tissue due to biosolids and manure amendments, and wastewater irrigation". Environment International, 82:110-112.

Malchi, T., Maor, Y., Tadmor, G., Shenker, M., Chefetz, B. (2014). Irrigation of Root Vegetables with Treated Wastewater: Evaluating Uptake of Pharmaceuticals and the Associated Human Health Risks. Environmental Science \& Technology, 48(16), 9325-9333.

Martínez-Zapata, M., Aristizábal, C., Peñuela, G. (2013). Photodegradation of the endocrine-disrupting chemicals 4n-nonylphenol and triclosan by simulated solar UV irradiation in aqueous solutions with $\mathrm{Fe}(\mathrm{III})$ and in the absence/presence of humic acids. Journal of Photochemistry and Photobiology A: Chemistry, 251, 41-49.

Martiniello, P. (1999). Effects of irrigation and harvest management on dry- matter yield and seed yield of annual clovers grown in pure stand and in mixtures with graminaceous species in a Mediterranean environment. Grass and Forage Science, 54, 52-61.

Mashtare, M. L., Lee, L. S., Nies, L. F., Turco, R. F. (2013). Transformation of 17 $\alpha$-Estradiol, 17 $\beta$-estradiol, and estrone in sediments under nitrate- and sulfate-reducing conditions. Environmental Science and Technology, 47(13), 7178-7185.

Matamoros, V., Duhec, A., Albaigés, J., Bayona, J. M. (2009). Photodegradation of carbamazepine, ibuprofen, ketoprofen and $17 \alpha$-ethinylestradiol in fresh and seawater. Water, Air, and Soil Pollution, 196(1-4), 161-168.

Matamoros, V., Rodríguez, Y. (2017). Influence of seasonality and vegetation on the attenuation of emerging contaminants in wastewater effluent-dominated streams. A preliminary study. Chemosphere, 186, 269277. 
Matsuoka, S., Kikuchi, M., Kimura, S., Kurokawa, Y., Kawai, S. (2005). Determination of Estrogenic Substances in the Water of Muko River Using in Vitro Assays, and the Degradation of Natural Estrogens by Aquatic Bacteria. Journal of Health Science, 51(2), 178-184.

Mazzini, R., Pedrazzi, L., Lazarova, V. (2013). Production of high quality recycled water for agricultural irrigation in Milan. In V. Lazarova, T. Asano, A. Bahri, J. Anderson (Eds.), Milestones in Water Reuse (pp. 179-190).

McArdell, C. S., Molnar, E., Suter, M. J. F., Giger, W. (2003). Occurrence and Fate of Macrolide Antibiotics in Wastewater Treatment Plants and in the Glatt Valley Watershed, Switzerland. Environmental Science and Technology, 37(24), 5479-5486.

Mejia Avendaño, S., Zhong, G., Liu, J. (2015). Comment on "Biodegradation of perfluorooctanesulfonate (PFOS) as an emerging contaminant." Chemosphere, 138, 1037-1038.

Mezcua, M., Gómez, M. J., Ferrer, I., Aguera, A., Hernando, M. D., Fernández-Alba, A. R. (2004). Evidence of 2,7/2,8-dibenzodichloro-p-dioxin as a photodegradation product of triclosan in water and wastewater samples. Analytica Chimica Acta, 524(1-2 SPEC. ISS.), 241-247.

Morrall, D., McAvoy, D., Schatowitz, B., Inauen, J., Jacob, M., Hauk, A., Eckhoff, W. (2004). A field study of triclosan loss rates in river water (Cibolo Creek, TX). Chemosphere, 54(5), 653-660.

Navarro, I., de la Torre, A., Sanz, P., Porcel, M. Á., Pro, J., Carbonell, G., Martínez, M. D. L. Á. (2017). Uptake of perfluoroalkyl substances and halogenated flame retardants by crop plants grown in biosolidsamended soils. Environmental Research, 152(October 2016), 199-206.

Nelli, E. and Sodi, F. (2007). Riso - Oryza sativa L. - Atlante delle coltivazioni erbacee - Piante industriali. URL: http://www.agraria.org/coltivazionierbacee/riso.htm. Last accessed: 5-10-2018.

NICNAS. (2009). Triclosan, Priority Existing Chemical Assessment Report.

Nielsen, C. J. (2012). PFOA Isomers, Salts, and Precursors.

Niu, J., Zhang, L., Li, Y., Zhao, J., Lv, S., Xiao, K. (2013). Effects of environmental factors on sulfamethoxazole photodegradation under simulated sunlight irradiation: Kinetics and mechanism. Journal of Environmental Sciences, 25(6), 1098-1106. 
Oliveira, C., Lima, D. L. D., Silva, C. P., Calisto, V., Otero, M., Esteves, V. I. (2019). Photodegradation of sulfamethoxazole in environmental samples: The role of $\mathrm{pH}$, organic matter and salinity. Science of the Total Environment, 648, 1403-1410.

Packer, J. L., Werner, J. J., Latch, D. E., McNeill, K., Arnold, W. A. (2003). Photochemical fate of pharmaceuticals in the environment: Naproxen, diclofenac, clofibric acid, and ibuprofen. Aquatic Sciences, 65(4), 342-351.

Pannu, M. W., Toor, G. S., O’Connor, G. A., Wilson, P. C. (2012). Toxicity and bioaccumulation of biosolids-borne triclosan in food crops. Environmental Toxicology and Chemistry, 31(9), 2130-2137.

Peuravuori, J., Pihlaja, K. (2009). Phototransformations of selected pharmaceuticals under low-energy UVAvis and powerful UVB-UVA irradiations in aqueous solutions-the role of natural dissolved organic chromophoric material. Analytical and Bioanalytical Chemistry, 394(6), 1621-1636.

Peuravuori, J. (2012). Aquatic photochemistry of paracetamol in the presence of dissolved organic chromophoric material and nitrate. Environmental Science and Pollution Research, 19(6), 2259-2270.

Poiger, T., Buser, H. R., Müller, M. D. (2001). Photodegradation of the pharmaceutical drug diclofenac in a lake: Pathway, field measurements, and mathematical modeling. Environmental Toxicology and Chemistry, 20(2), 256-263.

Poirier-Larabie, S., Segura, P. A., Gagnon, C. (2016). Degradation of the pharmaceuticals diclofenac and sulfamethoxazole and their transformation products under controlled environmental conditions. Science of the Total Environment, 557-558, 257-267.

Polesel, F., Plósz, B. G., Trapp, S. (2015). From consumption to harvest: Environmental fate prediction of excreted ionizable trace organic chemicals. Water Research, 84, 85-98.

Portmann, F., Siebert, S., Bauer, C., Döll, P. (2008). Global dataset of monthly growing areas of 26 irrigated crops. Frankfurt Hydrology Paper, 06, 400.

Prosser, R. S., Lissemore, L., Topp, E., Sibley, P. K. (2014). Bioaccumulation of triclosan and triclocarban in plants grown in soils amended with municipal dewatered biosolids. Environmental Toxicology and Chemistry, 33(5), 975-984. 
Prosser, R. S. and Sibley, P. K. (2015). Human health risk assessment of pharmaceuticals and personal care products in plant tissue due to biosolids and manure amendments, and wastewater irrigation. Environment International, 75:223-233.

Radke, M., Lauwigi, C., Heinkele, G., Múrdter, T. E., Letzel, M. (2009). Fate of the antibiotic sulfamethoxazole and its two major human metabolites in a water sediment test. Environmental Science and Technology, 43(9), 3135-3141.

Radke, M., Maier, M. P. (2014). Lessons learned from water/sediment-testing of pharmaceuticals. Water Research, 55, 63-73.

Radke, M., Ulrich, H., Wurm, C., Kunkel, U. (2010). Dynamics and attenuation of acidic pharmaceuticals along a river stretch. Environmental Science and Technology, 44(8), 2968-2974.

Rahman, M. F., Peldszus, S., Anderson, W. B. (2014). Behaviour and fate of perfluoroalkyl and polyfluoroalkyl substances (PFASs) in drinking water treatment: A review. Water Research, 50, 318-340.

Rawls, W. J., Brakensiek, D. L., Saxton, K. E. (1982). Estimation of soil water properties. American Society of Agricultural and Biological Engineers, 25(5), 1316-1320.

Rayne, S., Forest, K. (2009). Congener-specific organic carbon-normalized soil and sediment-water partitioning coefficients for the C 1 through C 8 perfluoroalkyl carboxylic and sulfonic acids. Journal of Environmental Science and Health, Part A, 44(13), 1374-1387.

Rayne, S., Forest, K. (2009). Perfluoroalkyl sulfonic and carboxylic acids : A critical review of physicochemical properties, levels and patterns in waters and wastewaters, and treatment methods Perfluoroalkyl sulfonic and carboxylic acids : A critical review of physicochemical prop. 4529.

Reichert, P., Vanrolleghem, P. (2001). Identifiability and uncertainty analysis of the River Water Quality Model No. 1 (RWQM1). Water Science and Technology, 43(7), 329-338.

Ren, D., Bi, T., Gao, S., Li, X., Huang, B., Pan, X. (2016). Photodegradation of 17a-ethynylestradiol in nitrate aqueous solutions. Environmental Engineering Research, 21(2), 188-195.

Ren, D., Huang, B., Xiong, D., He, H., Meng, X., Pan, X. (2017). Photodegradation of 17 $\alpha$-ethynylestradiol in dissolved humic substances solution: Kinetics, mechanism and estrogenicity variation. Journal of Environmental Sciences, 54, 196-205. 
Ren, D., Huang, B., Yang, B., Pan, X., Dionysiou, D. D. (2017). Mitigating 17A-ethynylestradiol water contamination through binding and photosensitization by dissolved humic substances. Journal of Hazardous Materials, 327, 197-205.

Rice Knowledge Bank. (2017). Measuring moisture content. Retrieved October 15, 2018, from http://www.knowledgebank.irri.org/step-by-step-production/postharvest/milling/milling-andquality/measuring-moisture-content-in-milling

Robinson, J. A., Ma, Q., Staveley, J. P., Smolenski, W. J., Ericson, J. (2017). Degradation and transformation of 17A-estradiol in water-sediment systems under controlled aerobic and anaerobic conditions. Environmental Toxicology and Chemistry, 36(3), 621-629.

Ryan, C. C., Tan, D. T., Arnold, W. A. (2011). Direct and indirect photolysis of sulfamethoxazole and trimethoprim in wastewater treatment plant effluent. Water Research, 45(3), 1280-1286.

Sabaliunas, D., Webb, S. F., Hauk, A., Jacob, M., Eckhoff, W. S. (2003). Environmental fate of Triclosan in the River Aire Basin, UK. Water Research, 37(13), 3145-3154.

Sabourin, L., Duenk, P., Bonte-Gelok, S., Payne, M., Lapen, D. R., Topp, E. (2012). Uptake of pharmaceuticals, hormones and parabens into vegetables grown in soil fertilized with municipal biosolids. Science of the Total Environment, 431, 233-236.

Sanchez-Prado, L., Llompart, M., Lores, M., García-Jares, C., Bayona, J. M., Cela, R. (2006). Monitoring the photochemical degradation of triclosan in wastewater by UV light and sunlight using solid-phase microextraction. Chemosphere, 65(8), 1338-1347.

Shenker, M., Harush, D., Ben-ari, J., Chefetz, B. (2011). Chemosphere Uptake of carbamazepine by cucumber plants - A case study related to irrigation with reclaimed wastewater. Chemosphere, 82(6), 905-910.

Silva, C. P., Lima, D. L. D., Otero, M., Esteves, V. I. (2016). Photosensitized Degradation of 17ß-estradiol and 17 $\alpha$-ethinylestradiol: Role of Humic Substances Fractions. Journal of Environment Quality, 45(2), 693-700.

Silva, C. P., Lima, D. L. D., Groth, M. B., Otero, M., Esteves, V. I. (2016). Effect of natural aquatic humic substances on the photodegradation of estrone. Chemosphere, 145, 249-255. 
Simonsen, J. F., Harremoës, P. (1978). Oxygen and pH fluctuations in rivers. Water Research, 12(7), 477489.

Singer, H., Müller, S., Tixier, C., Pillonel, L. (2002). Triclosan: Occurrence and fate of a widely used biocide in the aquatic environment: Field measurements in wastewater treatment plants, surface waters, and lake sediments. Environmental Science and Technology, 36(23), 4998-5004.

Stahl, T., Heyn, J., Thiele, H., Hüther, J., Failing, K., Georgii, S., Brunn, H. (2009). Carryover of perfluorooctanoic acid (PFOA) and perfluorooctane sulfonate (PFOS) from soil to plants. Archives of Environmental Contamination and Toxicology, 57(2), 289-298.

Stevens, J. B., Coryell, A. (2007). Surface Water Quality Criterion for Perfluorooctane Sulfonic Acid.

Su, T., Deng, H., Benskin, J. P., Radke, M. (2016). Biodegradation of sulfamethoxazole phototransformation products in a water/sediment test. Chemosphere, 148, 518-525.

Tabaglio, V., Ligabue, M., Reggiani, R., Piazza, C., Tassi, D., Ruozzi, F. (2007). Quale loglio italico scegliere per la campagna 2007-08. L’informatore Agrario, 35, 40-43.

Tixier, C., Singer, H. P., Canonica, S., Müller, S. R. (2002). Phototransformation of triclosan in surface waters: A relevant elimination process for this widely used biocide - Laboratory studies, field measurements, and modeling. Environmental Science and Technology, 36(16), 3482-3489.

Tixier, C., Singer, H. P., Oellers, S., Müller, S. R. (2003). Occurrence and Fate of Carbamazepine, Clofibric Acid, Diclofenac, Ibuprofen, Ketoprofen, and Naproxen in Surface Waters. Environmental Science \& Technology, 37(6), 1061-1068.

Tournaire-Roux, C., Sutka, M., Javot, H., Gout, E., Gerbeau, P., Luu, D. T., ... Maurel, C. (2003). Cytosolic $\mathrm{pH}$ regulates root water transport during anoxic stress through gating of aquaporins. Nature, 425(6956), 393-397.

USDA (2018). National Nutrient Database for Standard Reference Legacy Release - Basic Report: 11167, Corn, sweet, yellow, raw. URL: https://ndb.nal.usda.gov/ndb/foods/show/11167. Last accessed: 18-102018

Vaalgamaa, S., Vähätalo, A. V., Perkola, N., Huhtala, S. (2011). Photochemical reactivity of perfluorooctanoic acid (PFOA) in conditions representing surface water. Science of the Total Environment, 409(16), 3043-3048. 
Van der Vorm, P. D. J. (1980). Uptake of Si by five plant species, as influenced by variations in Si-supply. Plant and Soil, 56(1), 153-156.

Vanrolleghem, P., Borchardt, D., Henze, M., Rauch, W., Reichert, P., Shanahan, P., Somlyódy, L. (2001). River Water Quality Model no. 1 (RWQM1): III. Biochemical submodel selection. Water Science and Technology, 43(5), 31-40.

Vierke, L., Berger, U., Cousins, I. T. (2013). Estimation of the acid dissociation constant of perfluoroalkyl carboxylic acids through an experimental investigation of their water-to-air transport. Environmental Science and Technology, 47(19), 11032-11039.

Vochezer, K. (2010). Modelling of Carbamazepine and Diclofenac in a River Network by Modelling of Carbamazepine and Diclofenac in a River Network. Swedish University of Agricultural Sciences, Uppsala.

Wang, X. -L, Canny, M. J., McCully, M. E. (1991). The water status of the roots of soil-grown maize in relation to the maturity of their xylem. Physiologia Plantarum, 82(2), 157-162.

Wang, Z., MacLeod, M., Cousins, I. T., Scheringer, M., Hungerbühler, K. (2011). Using COSMOtherm to predict physicochemical properties of poly- and perfluorinated alkyl substances (PFASs). Environmental Chemistry, 8(4), 389-398.

Wen, B., Li, L., Zhang, H., Ma, Y., Shan, X., Zhang, S. (2014). Field study on the uptake and translocation of per fluoroalkyl acids (PFAAs) by wheat (Triticum aestivum L.) grown in biosolids-amended soils. Environmental Pollution, 184, 547-554.

Wen, B., Wu, Y., Zhang, H., Liu, Y., Hu, X., Huang, H. (2016). The roles of protein and lipid in the accumulation and distribution of per fluorooctane sulfonate (PFOS) and per fluorooctanoate (PFOA) in plants grown in biosolids-amended soils *. Environmental Pollution, 216, 682-688.

Whidbey, C. M., Daumit, K. E., Nguyen, T. H., Ashworth, D. D., Davis, J. C. C., Latch, D. E. (2012). Photochemical induced changes of in vitro estrogenic activity of steroid hormones. Water Research, 46(16), 5287-5296.

Willach, S., Lutze, H. V., Eckey, K., Löppenberg, K., Lüling, M., Wolbert, J. B., ... Schmidt, T. C. (2018). Direct Photolysis of Sulfamethoxazole Using Various Irradiation Sources and Wavelength Ranges - 
Insights from Degradation Product Analysis and Compound-Specific Stable Isotope Analysis. Environmental Science and Technology, 52(3), 1225-1233.

Williams, R. J., Johnson, A. C., Smith, J. J. L., Kanda, R. (2003). Steroid estrogens profiles along river stretches arising from sewage treatment works discharges. Environmental Science and Technology, 37(9), $1744-1750$.

Winker, M., Clemens, J., Reich, M., Gulyas, H., Otterpohl, R. (2010). Ryegrass uptake of carbamazepine and ibuprofen applied by urine fertilization. Science of The Total Environment, 408(8), 1902-1908.

Writer, J. H., Antweiler, R. C., Ferrer, I., Ryan, J. N., Thurman, E. M. (2013). In-stream attenuation of neuro-active pharmaceuticals and their metabolites. Environmental Science and Technology, 47(17), 9781-9790.

Writer, J. H., Ryan, J. N., Keefe, S. H., Barber, L. B. (2012). Fate of 4-nonylphenol and 17ß-estradiol in the Redwood River of Minnesota. Environmental Science and Technology, 46(2), 860-868.

Wu, C., Huang, X., Lin, J., Liu, J. (2015). Occurrence and Fate of Selected Endocrine-Disrupting Chemicals in Water and Sediment from an Urban Lake. Archives of Environmental Contamination and Toxicology, $68(2), 225-236$.

Wu, C., Spongberg, A. L., Witter, J. D., Sridhar, B. B. M. (2012). Transfer of wastewater associated pharmaceuticals and personal care products to crop plants from biosolids treated soil. Ecotoxicology and Environmental Safety, 85, 104-109.

Wu, C., Spongberg, A. L., Witter, J. D. (2009). Adsorption and Degradation of Triclosan and Triclocarban in Soils and Biosolids-Amended Soils. Journal of Agricultural and Food Chemistry, 57, 4900-4905.

Wu, C., Spongberg, A. L., Witter, J. D., Fang, M., Czajkowski, K. P. (2010). Uptake of Pharmaceutical and Personal Care Products by Soybean Plants from Soils Applied with Biosolids and Irrigated with Contaminated Water. Environmental Science \& Technology, 44(16), 6157-6161.

Wu, L., Gao, H.-W., Gao, N., Chen, F.-F., Chen, L. (2009). Interaction of perfluorooctanoic acid with human serum albumin. BMC Structural Biology, 9(1), 31.

Xing, L., Spitler, J. D. (2017). Prediction of undisturbed ground temperature using analytical and numerical modeling. Part I: Model development and experimental validation. Science and Technology for the Built Environment, 23(5), 787-808. 
Xu, B., Mao, D., Luo, Y., Xu, L. (2011). Sulfamethoxazole biodegradation and biotransformation in the water-sediment system of a natural river. Bioresource Technology, 102(14), 7069-7076.

Xu, J., Wu, L., Chang, A. C. (2009). Degradation and adsorption of selected pharmaceuticals and personal care products (PPCPs) in agricultural soils. Chemosphere, 77(10), 1299-1305.

Yager, T. J. B., Furlong, E. T., Kolpin, D. W., Kinney, C. A., Zaugg, S. D., Burkhardt, M. R. (2014). Dissipation of Contaminants of Emerging Concern in Biosolids Applied to Nonirrigated Farmland in Eastern Colorado. JAWRA Journal of the American Water Resources Association, 50(2), 343-357.

Yagi, N., Kenmotsu, H., Sekikawa, H., Takada, M. (1991). Studies on the Photolysis and Hydrolysis of Furosemide in Aqueous Solution. Chemical \& Pharmaceutical Bulletin, 39, 454-457.

Yamamoto, H., Nakamura, Y., Moriguchi, S., Nakamura, Y., Honda, Y., Tamura, I., ... Sekizawa, J. (2009). Persistence and partitioning of eight selected pharmaceuticals in the aquatic environment: Laboratory photolysis, biodegradation, and sorption experiments. Water Research, 43(2), 351-362.

Yoo, H., Washington, J. W., Jenkins, T. M., Ellington, J. J. (2011). Quantitative determination of perfluorochemicals and fluorotelomer alcohols in plants from biosolid-amended fields using LC/MS/MS and GC/MS. Environmental Science and Technology, 45(19), 7985-7990.

Zhang, N., Li, J. M., Liu, G. G., Chen, X. L., Jiang, K. (2017a). Photodegradation of diclofenac in aqueous solution by simulated sunlight irradiation: Kinetics, thermodynamics and pathways. Water Science and Technology, 75(9), 2163-2170.

Zhang, Y., Biswas, A., Adamchuk, V. I. (2017b). Implementation of a sigmoid depth function to describe change of soil pH with depth. Geoderma, 289, 1-10.

Zhang, N., Liu, G., Liu, H., Wang, Y., He, Z., Wang, G. (2011). Diclofenac photodegradation under simulated sunlight: Effect of different forms of nitrogen and Kinetics. Journal of Hazardous Materials, $192(1), 411-418$

Zhang, W., Webster, E. P. (2002). Shoot and root growth of rice (Oryza sativa) in response to V-10029. Weed Technology, 16(4), 768-772.

Zhang, Y., Xu, J., Zhong, Z., Guo, C., Li, L., He, Y., ... Chen, Y. (2013). Degradation of sulfonamides antibiotics in lake water and sediment. Environmental Science and Pollution Research, 20(4), 2372-2380. 
Zhang, Y., Sangster, J. L., Gauza, L., Bartelt-Hunt, S. L. (2016). Impact of sediment particle size on

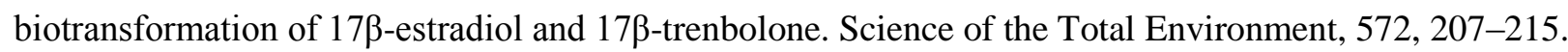

Zhao, S., Fan, Z., Sun, L., Zhou, T., Xing, Y., Liu, L. (2017a). Interaction effects on uptake and toxicity of perfluoroalkyl substances and cadmium in wheat (Triticum aestivum L.) and rapeseed (Brassica campestris L.) from co-contaminated soil. Ecotoxicology and Environmental Safety, 137(July 2016), 194-201.

Zhao, S., Fang, S., Zhu, L., Liu, L., Liu, Z., Zhang, Y. (2014). Mutual impacts of wheat (Triticum aestivum L .) and earthworms (Eisenia fetida) on the bioavailability of per fluoroalkyl substances (PFASs) in soil. Environmental Pollution, 184, 495-501.

Zhao, W., Wang, B., Wang, Y., Deng, S., Huang, J., Yu, G. (2017b). Deriving acute and chronic predicted no effect concentrations of pharmaceuticals and personal care products based on species sensitivity distributions. Ecotoxicology and Environmental Safety, 144(February), 537-542.

Zuo, Y., Zhang, K., Zhou, S. (2013). Determination of estrogenic steroids and microbial and photochemical degradation of $17 \alpha$-ethinylestradiol (EE2) in lake surface water, a case study. Environmental Sciences: Processes and Impacts, 15(8), 1529-1535. 